UNIVERSIDADE DE SÃO PAULO

PROGRAMA DE PÓS-GRADUAÇÃO EM ENERGIA

EP-FEA-IEE-IF

RENATA FONSECA CABRAL

ESTIMATIVA ECONOMÉTRICA DAS ELASTICIDADES RENDA E PREÇO DA DEMANDA POR GÁS NATURAL PARA O SETOR INDUSTRIAL BRASILEIRO 
RENATA FONSECA CABRAL

\title{
ESTIMATIVA ECONOMÉTRICA DAS ELASTICIDADES RENDA E PREÇO DA DEMANDA POR GÁS NATURAL PARA O SETOR INDUSTRIAL BRASILEIRO
}

\begin{abstract}
Dissertação apresentada ao Programa de PósGraduação em Energia da Universidade de São Paulo - (Escola Politécnica / Faculdade de Economia, Administração e Contabilidade / Instituto de Eletrotécnica e Energia / Instituto de Física) - para obtenção do título de Mestre em Ciências.
\end{abstract}

Orientadora: $\operatorname{Prof}^{\mathrm{a}} \operatorname{Dr}^{\mathrm{a}}$ Virginia Parente

\section{Versão Corrigida}

(Versão original disponível na Biblioteca da Unidade que aloja o Programa e na Biblioteca Digital de Teses e Dissertações da USP.)

\section{São Paulo}

2013 
AUTORIZO A REPRODUÇÃO E DIVULGAÇÃO TOTAL OU PARCIAL DESTE TRABALHO, POR QUALQUER MEIO CONVENCIONAL OU ELETRÔNICO, PARA FINS DE ESTUDO E PESQUISA, DESDE QUE CITADA A FONTE.

FICHA CATALOGRÁFICA

Renata, Fonseca Cabral

Estimativa Econométrica das Elasticidades Renda e Preço da Demanda do Setor Industrial Brasileiro / Renata Fonseca Cabral; orientadora Virginia Parente - São Paulo, 2013

124 p.: il.; $30 \mathrm{~cm}$.

Dissertação (Mestrado) - Programa de Pós-Graduação em Energia - EP / FEA / IEE / IF da Universidade de São Paulo.

1. Gás natural - 2. Elasticidade Preço e Renda I. Título.I 
FOLHA DE APROVAÇÃO 


\section{AGRADECIMENTOS}

Meu agradecimento mais do que especial à minha orientadora, Prof ${ }^{\text {a. }}$ Virginia Parente, pessoa brilhante por quem tenho profundo respeito e admiração. Agradeço pelas conversas incrivelmente inspiradoras e por ter acreditado em minha capacidade, o que proporcionou a oportunidade de realizar este trabalho.

Agradeço minha querida irmã Rosangela Cabral, grande amiga, que desde pequena me apoia incondicionalmente. Confiar que você sempre estará ao meu lado é um incentivo extraordinário para todas as realizações da minha vida.

Ao Prof. Iram Jacome Rodrigues pelo apoio à entrada no Programa de Mestrado e pelas discussões absolutamente profundas e enriquecedoras durante a graduação em Economia na FEA-USP. Suas aulas são inesquecíveis.

Aos professores e funcionários do IEE/USP pela ajuda e suporte durante todo o Programa. 
"É esta força que mantém sempre a opinião justa e legítima sobre o que é necessário temer e não temer, que chamo e defino coragem."

Platão 


\section{RESUMO}

CABRAL, Renata Fonseca. Estimativa Econométrica das Elasticidades Renda e Preço da Demanda por Gás Natural para o Setor Industrial Brasileiro. 119f. Dissertação (Mestrado em Ciências) - Programa de Pós-Graduação em Energia da Universidade de São Paulo, São Paulo, 2013.

Este trabalho tem como objetivo estimar a elasticidade renda e preço da demanda por gás natural no Brasil para o setor industrial brasileiro. $\mathrm{O}$ segmento de consumo industrial representa cerca de dois terços do consumo de gás natural no país, destacando sua importância estratégica na elaboração de política energética relacionada ao gás. Este trabalho apresenta também o incremento nas trocas internacionais de gás natural e a perspectiva de aumento do uso desse energético no Brasil e no mundo. Alguns desafios ainda se colocam para a efetiva globalização dessa indústria, como: a necessidade de realização de investimentos em infraestrutura de produção, transporte e distribuição; o aprimoramento do acesso às principais reservas do hidrocarboneto; e as incertezas com relação à evolução da demanda. Utiliza-se o estudo estatístico econométrico para estimar as elasticidades preço e renda, ou seja, para investigar como a demanda industrial brasileira reage frente a um aumento ou diminuição de preço do gás e das variações na renda disponíveis no Brasil. Como proxy da renda industrial utilizam-se os dados do PIB industrial brasileiro. Após identificar que as séries estudadas eram não estacionárias, optou-se pela utilização do conceito de cointegração, aplicando-se o Modelo de Correção de Erros Vetoriais (VEC Model). Os resultados obtidos por meio do referido modelo mostraram que a demanda estudada é muito mais sensível a variações do preço do gás natural do que a variações na renda. Desse modo, constatouse que, no Brasil, preços mais competitivos obtêm melhores resultados para o crescimento da demanda por gás natural do que aumentos da renda.

Palavras-chave: Gás natural; Brasil; Energia; Elasticidade-preço; Elasticidade-renda; Cointegração; VEC Model. 


\begin{abstract}
CABRAL, Renata Fonseca. Econometric Forecasts: A Study on Long-Term Price and Income Elasticity for Natural Gas in the Brazilian Industrial Sector. 119f. Master's Dissertation, Graduate Program on Energy, Universidade de São Paulo, São Paulo, 2013.

The purpose of the present study is to estimate the elasticity, mainly in terms of price and income, of the demand for gas natural in the Brazilian industrial sector. The industry represents around two-thirds of the natural gas consumption in the country, highlighting strategic importance in creating energy policy related to natural gas. This paper also presents the evolution in international trade of natural gas and the perspectives of increased in the use of this energy source in Brazil and worldwide. Some challenges still lay ahead for effective intensification of the gas industry in the country, such as: the increase of investments in infrastructure for production, transport and distribution; the development to the access to major hydrocarbon reserves; the improvements to deal with uncertainties regarding the evolution of demand. Econometric tools are used to estimate price and income elasticity for the Brazilian industrial sector, in other words, to investigate how the natural gas demand reacts to an increase / decrease in the price of gas and in the available income. The industrial GDP is used as a proxy for income. After determining that the series under study were nonstationary, the co-integration approach was chosen and Vector Error Correction Model (VEC Model) was applied. The obtained results show that the price elasticity in the industrial sector in Brazil is significantly higher than income elasticity.
\end{abstract}

Keywords: Natural Gas; Brazil; Energy; Price Elasticity; Income Elasticity; Cointegration; VEC Model. 


\section{LISTA DE FIGURAS}

Figura 1 - Evolução das exportações e/ou importações líquidas de gás natural no Brasil 18

Figura 2 - Comparação entre os custos de transporte de petróleo e de gás natural 26

Figura 3 - Mercados de gás natural $\quad 29$

Figura 4 - EUA reserva de mercado e produção a partir de 1940

Figura 5 - Mapa de rede de gasodutos dos EUA 32

Figura 6 - Evolução do consumo de gás natural nos EUA (1979-2025) 33

Figura 7 - Mapa de rede de gasodutos dos EUA 34

Figura 8 - Principais linhas de conexão de gás natural na europa continental) $\quad 40$

Figura 9 - Overview da dependência de importação no mercado europeu 46

Figura 10 - Valor de mercado das maiores companhias europeias de gás natural $\quad 47$

Figura 11 - Mercado de gás natural em UK 48

Figura 12 - Mercado de gás natural em UK produção e consumo 49

Figura 13 - Infraestrutura de transporte de gás natural no Reino Unido 52

Figura 14 - Demanda por gás natural Ásia-Pacífico 1990-2016 53

Figura 15 - Contratos de curto e longo prazo de GNL Asia-Pacifico 55

Figura 16 - Preço médio importação de GNL pelo Japão 60

Figura 17 - Mapa do traçado do Gasoduto Brasil-Bolívia 62

Figura 18 - Reserva, consumo e produção de gás natural na América do Sul 66

Figura 19 - Infraestrutura de produção e transporte de gás natural na América do Sul 67

Figura 20 - Reservas provadas de gás natural no Brasil de 1965 a 2009

Figura 21 - Evolução das reservas brasileiras provadas de gás natural $\quad 70$

Figura 22 - Consumo de gás natural no Brasil - Por setor 71

Figura 23 - Evolução do consumo industrial de gás natural (10³ TEP) 74 
Figura 24 - Volume de reservas provadas por estado da federação

Figura 25- Distribuição da produção de gás natural por estado

Figura 26 - Campos com maior produção de gás natural

Figura 27 - Distribuição da produção de gás natural por bacia

Figura 28- Distribuição da produção de gás natural por operador

Figura 29 - Rede brasileira de gasodutos

Figura 30 - Distribuidoras brasileiras de gás natural

Figura 31 - Consumo de gás natural nas usinas termelétricas no Brasil 


\section{LISTA DE TABELAS}

Tabela 1- Resumo produção e importação de gás natural no Brasil no ano de 2012

Tabela 2 - Capacidade nominal de processamento de gás natural existente

Tabela 3 - Preços do gás natural no Brasil (2009-2012)

Tabela 4 - Fontes e dados utilizados

Tabela 5 - Resultados do teste de raiz unitária ADF - Variáveis em nível

Tabela 6 - Resultados do teste de raiz unitária ADF - Variáveis em primeira

diferença

Tabela 7 - Definição do número de defasagens do VAR

Tabela 8 - Teste do $\lambda$-traço

Tabela 9 - Coeficientes normalizados

Tabela 4 - Fontes e dados utilizados 


\section{LISTA DE ABREVIATURAS E SIGLAS}

ABEGÁS

Canalizado

AGENERSA

Janeiro

ANEEL

ANP

ARSESP

Paulo

Bar

Bahiagás

BBRB

BBRL

BEN

CAPEX

CEG

CEG RIO

Compagás

CDL

CI

CMPC

Comgás

CSLL

EIA

EVA

FGTS

FINAME

FINEP

FMI

FNE
Associação Brasileira das Empresas Distribuidoras de Gás

Agência Reguladora de Energia e Saneamento Básico do Rio de

Agência Nacional de Energia Elétrica

Agência Nacional do Petróleo, Gás Natural e Biocombustíveis

Agência Reguladora de Saneamento e Energia do Estado de São

Unidade de Pressão

Companhia de Gás da Bahia

Base de Remuneração Regulatória Bruta

Base de Remuneração Regulatória Líquida

Balanço Energético Nacional

Gastos de Capital

Companhia de Distribuição de Gás do Rio de Janeiro

Companhia de Distribuição de Gás do Rio de Janeiro

Companhia Paranaense de Gás

Companhias Distribuidoras Locais

Capital Investido

Custo Médio Ponderado de Capital

Companhia de Gás de São Paulo

Contribuição Social sobre o Lucro Líquido

Energy Information Association

Economic Value Added (Valor Econômico Agregado)

Fundo de Garantia por Tempo de Serviço

Agência Especial de Financiamento Industrial

Financiadora de Estudos e Projetos

Fundo Monetário Internacional

Fundo Nacional de Eletrificação 
FURNAS

FCD

F-T

Gasbol

GLP

GN

GNC

GNL

GNV

GTL

IGN

IR

MM

MME

NOPAT

OPEP

OPEX

Plangás

Petrobras

PIB

PND

PNE

PNMA

PPA

RE-SEB

RTE

SEMA

SIN

SPE

TR

TBG

TNS

UPGN
Furnas Centrais Elétricas

Fluxo de Caixa Descontado

Fischer Tropsch

Gasoduto Bolívia-Brasil

Gás Liquefeito de Petróleo

Gás Natural

Gás Natural Comprimido

Gás Natural Liquefeito

Gás Natural Veicular

Gás to Liquids

Indústria de Gás Natural

Imposto de Renda

Margem Máxima

Ministério de Minas e Energia

Net Operating Profit After Taxes

Organização dos Países Exportadores de Petróleo

Custos e Despesas Operacionais

Plano de Antecipação da Produção de Gás

Petróleo Brasileiro S.A.

Produto Interno Bruto

Programa Nacional de Desestatização

Plano Nacional de Eletrificação

Política Nacional do Meio Ambiente

Power Purchase Agreement

Reestruturação do Setor Elétrico Brasileiro

Recomposição de Tarifa Extraordinária

Secretaria Especial de Meio Ambiente

Sistema Interligado Nacional

Sociedade de Propósito Específico

Taxa Referencial

Transportadora Brasileira Gasoduto Bolívia-Brasil

Transportadora do Nordeste e Sudeste

Unidade de Processamento de Gás Natural 


\section{SUMÁRIO}

1. INTRODUÇÃO 16

1.1. Justificativa do Tema 16

1.2. Objetivos Principal e Secundário 21

1.3. Questão Central e Hipótese 21

1.4. Metodologia 22

$\begin{array}{ll}\text { 1.5. Estrutura Capitular } & 22\end{array}$

2. PERSPECTIVA HISTÓRICA DA INDÚSTRIA DO GÁS NATURAL 30

2.1 Mercado de Gás Natural na América do Norte 30

2.11 Regulação nos EUA

2.2 Mercado de Gás Natural na Europa Continenta 39

2.3 Mercado de Gás Natural no Reino Unido $\quad 47$

2.4 Mercado de Gás Natural na Ásia

2.5 Mercado de Gás Natural na América do Sul $\quad 61$

3. O GÁS NATURAL NO BRASIL 67

3.1. Breve Histórico da Indústria do Gás Natural 68

3.2. A Participação do Gás Natural como Energia Primária no Brasil 69

3.3. As Reservas de Gás Natural no Brasil $\quad 74$

3.4. A Produção e a Oferta de Gás Natural no Brasil 76

3.5. A Importação de Gás Natural no Brasil $\quad 78$

3.6. A Infraestrutura de Processamento de Gás Natural no Brasil 79

3.7. A Infraestrutura de Transporte de Gás Natural no Brasil 81

3.8. A Distribuição de Gás Natural No Brasil $\quad 83$

3.9. A Precificação do Gás Natural no Brasil 84

3.10. Consumo Termoelétrico do Gás Natural no Brasil 85 
4. MODELO ECONOMÉTRICO DE ESTIMATIVA DAS ELASTICIDADES PREÇO E RENDA DO SETOR INDUSTRIAL BRASILEIRO

4.1. Revisão da Literatura $\quad 88$

4.2. Definições do Modelo Microeconômico 93

4.2.1. Teoria da Firma 93

4.2.2. Aplicando a Teoria da Firma para Maximização de Lucro da Indústria 96

4.2.3. A Elasticidade Preço e Renda 100

4.2.4. Cointegração 101

4.2.5. Dados Utilizados 103

4.2.6. Estimação das Elasticidades e Resultados Obtidos 106

4.2.6.1. Equação com as Elasticidades Obtidas - Resultados 108

5. CONCLUSÕES 110

BIBLIOGRAFIA $\quad 113$ 


\section{INTRODUÇÃO}

Neste primeiro capítulo, de natureza introdutória, são apresentados a justificativa e a relevância do tema escolhido, os objetivos principal e secundário a que se propõem a presente pesquisa, a questão central e a hipótese que se pretende testar e, por fim, a metodologia escolhida, bem como a estrutura capitular para a concretização da pesquisa.

\subsection{Justificativa do Tema}

O gás natural ocupa hoje a segunda posição na matriz energética mundial, com uma participação de 15,6\% na demanda total de energia primária (BP, 2012), ficando atrás somente do petróleo, que possui a maior fatia, respondendo por $41,6 \%$ do consumo total de energia no mundo. No Brasil, o gás natural representa 6,9\% da demanda energética, sendo que dez anos antes (1992) o gás representava 3,3\% da demanda energética do país (EPE 2012).

Tal crescimento foi impulsionado por ações de incentivo por parte do governo federal para o crescimento do consumo desse combustível no Brasil, como incentivos tarifários para indústrias que convertessem seus fornos movidos a lenha ou óleo combustível para gás natural, investimentos em usinas termelétricas, em aluguéis de navios metaneiros, com a finalidade de importação de gás natural liquefeito (GNL) do Oriente Médio e com a construção do Gasoduto Bolívia-Brasil (Gasbol).

O consumo de gás natural em 2012 mostra que o mercado continua em expansão. De acordo com os dados estatísticos da Associação Brasileira das Empresas Distribuidoras de Gás Canalizado (ABEGÁS), 2012 apresentou crescimento de 35,53\% em relação à média do ano de 2011. O volume de gás natural comercializado atingiu a média diária de consumo de 52,9 milhões de metros cúbicos de gás. O consumo de gás natural apresentou crescimento graças ao aumento no despacho térmico e também à retomada da demanda para o segmento industrial após a baixa de consumo dos anos de crise 2008/2009. 
O setor que mais influenciou esse resultado foi o de geração elétrica, que cresceu $171,06 \%$ de um ano para o outro, graças ao maior acionamento térmico em virtude do baixo nível de água dos reservatórios. Em 2012, como nos anos anteriores, o principal consumidor do gás natural foi o setor industrial, com 26,2 milhões $\mathrm{m}^{3} / \mathrm{dia}$, o que representa um aumento de 20,15\% com relação ao ano anterior. Na sequência, estão os setores de cogeração, residencial e comercial, com aumento de, respectivamente, $19,64 \%, 7,24 \%$ e 6,26\% no consumo diário de gás natural.

Historicamente, a utilização de gás natural no Brasil mostrou-se reduzida, sendo bastante recente e estando muito concentrada em alguns poucos estados e em determinados segmentos do setor industrial brasileiro.

O Programa Prioritário de Termeletricidade, criado em 2001, cuja finalidade básica foi promover a expansão, no curto prazo, da capacidade instalada de geração de energia elétrica no país por meio das usinas termelétricas movidas a gás natural foi um importante incentivo para esse tipo de indústria no Brasil.

O futuro do gás natural no Brasil, com a descoberta do pré-sal, revela um cenário de abundância desse combustível. Estimativas da Petrobras apontam que a área de pré-sal abaixo da Bacia de Campos tem potencial para produzir 120 milhões de metros cúbicos $\left(\mathrm{m}^{3}\right)$ de gás por dia. De acordo com Marcos Tavares, sócio diretor da consultoria Gás Energy, essa produção seria suficiente para garantir a autossuficiência do país, exportar para países vizinhos e servir como insumo para a indústria química nacional. $\mathrm{O}$ consumo nacional gira em torno de 60 milhões $\left(\mathrm{m}^{3}\right)$, sendo que metade desse volume é importada da Bolívia. A Figura 1 mostra a evolução das importações líquidas de gás natural no Brasil.

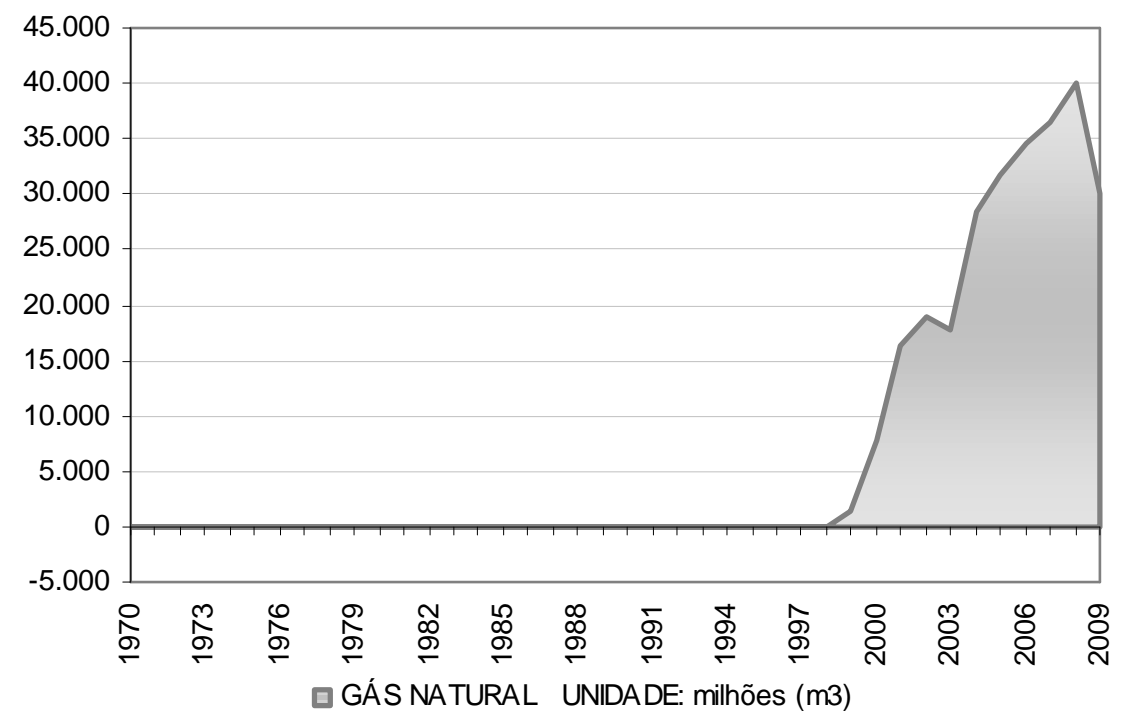


Figura 1 - Evolução das exportações e/ou importações líquidas de gás natural no Brasil Fonte: (EPE 2012)

De acordo com Checci et all, entre 1998 e 2000, verificou-se uma profunda mudança na matriz energética brasileira, que deverá ter efeitos duradouros na economia do país: a chamada "decolagem" do consumo do gás natural. Como primeiro resultado desta mudança, espera-se que o gás natural abandone uma posição por longo tempo residual no Balanço Energético e assuma o papel de vetor de desenvolvimento e integração nacional.

De maneira oficial, este é um objetivo perseguido, desde meados da década de 1980, quando o Ministério das Minas e Energia aventou pela primeira vez essa possibilidade e elaborou o Plano Nacional do Gás Natural (Plangás), que, no entanto, não teve prosseguimento (CHECCHI et al., 2001).

Fato também não desprezível neste contexto é a redução dos custos de investimento das tecnologias que se utilizam do gás natural. Plantas térmicas baseadas em turbinas a gás, por exemplo, têm apresentado um custo de geração de energia elétrica decrescente nas últimas duas décadas, em função, principalmente, do incremento de performance dos equipamentos, o que deve ser atribuído ao emprego de materiais mais resistentes às altas temperaturas e ao resfriamento das palhetas da turbina (SZKLO, 2007).

Assim, os potenciais ganhos derivados das economias de escala, que eram tradicionalmente assumidos pelo planejamento centralizado da oferta de eletricidade, e o consequente tratamento de monopólio natural conferido à geração de energia elétrica, passaram a ser contestados pelas tecnologias a gás natural. Em outras palavras, a competição no segmento de geração de energia elétrica, somente passível de ocorrer em um contexto no qual os ganhos de escala e as barreiras à entrada e à saída de competidores não são elevados, em tese, tornou-se possível com a redução da ótima escala de geração, derivada dos ganhos de eficiência das tecnologias a gás natural (MOUTINHO, 2002). 
De acordo com o Plano Decenal de Energia 2012/2021, para que não ocorram problemas no fornecimento de gás natural, é necessário que a infraestrutura seja suficiente para transportar o gás natural de sua fonte produtora até o consumidor final. Esta infraestrutura é, portanto, um ponto fundamental de todo o sistema e deve ser dimensionada de forma a permitir que o gás natural, produzido ou importado, possa chegar aos mercados consumidores de forma segura. A ampliação da infraestrutura está diretamente ligada ao ambiente regulatório de garantia de retorno de investimento do capital investido.

O risco de desabastecimento de gás natural a partir de 2006 devido à estatização das reservas de gás natural da Bolívia, que na presente data, é o local de onde chega $50 \%$ do gás consumido no Brasil, impulsionou o desenvolvimento de uma legislação federal mais específica para a indústria desse energético. Também demarcou um passo determinante para o aumento da competição no setor, reduzindo as tarifas e diminuindo a dependência externa. Espera-se que tais medidas venham a atrair novos agentes e maiores investimentos.

A Lei do Gás, aprovada pela Câmara em 2008 e regulamentada pelo Presidente da República em dezembro de 2010, tem como objetivo destravar o crescimento da indústria do setor e preencher o vácuo da ausência de regras claras que garantam o retorno do capital investido.

De acordo com Moutinho (2009), a lei inovou quando acrescentou uma nova estrutura jurídica para a exploração das atividades de transporte de gás natural por dutos. Introduziu-se a modalidade de concessão convivendo com a autorização, já utilizada desde a Lei do Petróleo, de 1997. O sucesso da lei em promover investimentos poderá depender de forças maiores. Existe, portanto, um processo evolutivo (político, econômico e estratégico) extremamente complexo, envolvendo inúmeras incertezas, o qual será influenciado, e também influenciará, pela aplicação da lei.

De acordo com Parente, et al., 2006, o aporte privado pode ser bastante útil para compor o esforço de investimentos na infraestrutura necessária. As agências reguladoras, por sua vez, podem ter aí uma função crucial de redução dos custos 
vislumbrados e da fiscalização de preço e qualidade necessários quando um serviço ou produto é ofertado por mãos outras que não as do Estado. Quando a redução do risco é visualizada pelos potenciais empreendedores, o custo do investimento se reduz e tende, também, a se realizar com mais rapidez.

Ainda de acordo com Parente (2006), também, os provedores de capital de terceiros, como os bancos e fundos de pensão nacionais e internacionais, entendem que emprestar recursos para empresas e empreendimentos de risco mais baixo poderá levá-los a pedir menos pelo capital emprestado. Assim, tanto do lado do equity (investidores diretos) quanto do debt (dívida contraída com capital de terceiros, como o de bancos) o custo fica mais baixo diante de um risco menor.

Ademais, duas características relevantes da indústria do gás natural - seu elevado custo de transporte e a existência de energéticos substitutos - fazem com que sua penetração no mercado seja, em geral, balizada pelo preço desses energéticos (por exemplo: óleo combustível, eletricidade ou outros derivados de petróleo) e pelos custos de sua cadeia de produção, transporte, distribuição e comercialização, os quais são relativamente rígidos em função do transporte (SZKLO, 2007).

Apesar de os números de aumento de demanda serem otimistas, os altos preços ainda foram um desafio para o mercado nacional, em 2012, e deve ser ainda nos próximos anos. O gás natural já se mostrou importante para uma matriz energética mais sustentável, mas para entender a expansão ainda maior dessa demanda é necessário acompanhar a evolução dos preços do gás e dos bens substitutos.

Logo, para que seja possível a proposição de soluções para a ampliação da infraestrutura de transporte de gás natural no Brasil, é importante que estejam claramente definido e quantificado o possível desequilíbrio entre oferta e demanda das indústrias demandantes deste combustível, permitindo, assim, a melhor avaliação das necessidades específicas desse setor.

Com este propósito, as seções que se seguem farão uma abordagem que especifica o gás natural no segmento industrial, além de um mapeamento das necessidades energéticas 
deste segmento de consumo. Em seguida, veremos o modelo microeconômico e a abordagem econométrica a ser utilizada.

\subsection{Objetivos Principal e Secundário}

O objetivo principal da dissertação é estimar a elasticidade renda e elasticidade preço da demanda por gás natural do setor industrial brasileiro por meio do modelo de econométrico de cointegração, utilizando dados do Produto Interno Bruto industrial (PIB), preço de gás natural e também o preço de bem substituto, que, no caso do consumo industrial, será utilizado o preço da energia elétrica. Como objetivo secundário, será realizado um panorama histórico mundial do consumo desse energético por geografias (América do Norte, Europa Continental, Reino Unido, Ásia e América do Sul), assim como sua introdução, evolução e participação na matriz energética brasileira, infraestrutura relacionada à sua distribuição e precificação.

\subsection{Questão Central e Hipótese}

O estudo da demanda de gás natural para o segmento de consumo industrial no Brasil tem importância estrutural e conjuntural, tanto no planejamento quanto no gerenciamento do setor de gás natural no Brasil, uma vez que exerce impacto direto e/ou indireto sobre as decisões de programas decenais de expansão da geração; planejamento da operação dos sistemas; programas de investimentos das empresas; contratos de compra e venda de energia entre empresas; preço da energia; programa de licitação de obras do agente regulador; entre outros.

No contexto de grandes mudanças estruturais da indústria de gás natural no Brasil, já introduzidos no item anterior, a questão central da dissertação é calcular a elasticidade renda e preço da demanda de longo prazo do consumo de gás natural para o segmento industrial.

Será analisado como este segmento de consumo tem se comportado diante das oscilações de duas variáveis: i) variação de preço do combustível gás natural em relação ao combustível substituto - energia elétrica (elasticidade preço) e; ii) variação da renda 
- PIB industrial que possibilita a troca de equipamentos e o aumento de consumo de energia (elasticidade renda).

\subsection{Metodologia}

Para responder à questão central proposta no item anterior, bem como atender aos objetivos principal e secundário propostos, a metodologia está subdividida em duas vertentes. A primeira contempla uma abordagem histórica da evolução da indústria do gás natural mundial e, em seguida, a indústria do gás no Brasil. Já a segunda vertente contempla o uso da metodologia econométrica para estimar as elasticidades preço e renda de demanda do setor industrial brasileiro.

1) Revisão da literatura sobre a expansão do consumo do gás natural no mundo, com um panorama detalhado por região i) América do Norte; ii) Europa Continental; iii) Reino Unido; iv) Ásia; v) América do Sul incluindo o Gasbol. Em seguida, será feito um mapeamento detalhado da evolução do uso de gás natural no Brasil, sua distribuição e precificação.

2) Aplicação do teste de cointegracao em estudos de gás natural com a revisão da literatura, apresentação da metodologia referente ao teste, aplicação do modelo para estimar as elasticidades preço e renda de demanda de gás natural do setor industrial brasileiro.

\subsection{Estrutura Capitular}

O tema proposto será desenvolvido em seis capítulos, que pretendem dar um panorama histórico mundial da utilização do gás natural, para, em seguida, explicar o histórico brasileiro e então realizar as estimativas econométricas das elasticidades preço e renda de demanda.

Além da introdução do tema, que contempla os objetivos e questão central, e a conclusão, respectivamente capítulos um e cinco, esta dissertação pretende mostrar no Capítulo 2 uma perspectiva histórica da indústria do gás natural no mundo, 
subdividindo a analise por geografias, começando pela América do Norte, Europa Continental, Reino Unido, Ásia e América do Sul.

No Capitulo 3 será feito uma exposição do histórico, das reservas, da produção, da infraestrutura e da distribuição do gás natural no Brasil. Com a entrada em operação do Gasoduto Bolívia-Brasil, em fevereiro de 1999, o país finalmente passou a dispor de suprimentos de gás natural em quantidades significativas, atingindo, assim, uma escala economicamente competitiva nesse tipo de energético. É natural que a disponibilidade de gás natural em grandes quantidades traga questionamentos sobre sua utilização final. Tópicos como o nascimento desta indústria, sua evolução, as principais regiões consumidoras, a importância do gás na matriz energética, o perfil de consumo no Brasil etc. são discutidos com o objetivo de contextualizar os outros capítulos da dissertação.

O Capítulo 4 apresenta a fundamentação teórica utilizada no estudo. Este capítulo apresenta as premissas básicas adotadas para a realização dos cálculos econométricos, assim como a justificativa da escolha do modelo estatístico em questão. Também são apresentados os resultados dos testes.

Por fim, o Capítulo 5 apresenta algumas considerações finais e as conclusões do estudo realizado. 


\section{PERSPECTIVA HISTÓRICA DA INDÚSTRIA DO GÁS NATURAL}

O uso do gás natural em grande escala pode ser considerado um fenômeno recente, ocorrido no século XX. Contudo, há registros de utilização desse hidrocarboneto para fins de iluminação já em 1821, nos Estados Unidos. O primeiro registro de utilização de gás natural, ainda no século XIX, foi o uso do gás natural associado à produção de petróleo do campo de Baku, em 1871 (CORRELJÉ, 2004).

O desenvolvimento da indústria de gás natural obedeceu às características técnicas e econômicas específicas às diferentes atividades da cadeia de valor desse energético. A indústria de gás natural é uma indústria de rede, ou seja, uma indústria composta por diferentes atividades organizadas sob a forma de uma rede física necessária à sua operação e prestação do serviço. A provisão de gás natural aos consumidores só é possível porque existe uma rede física responsável pela produção, tratamento, transporte e distribuição desse hidrocarboneto.

Uma característica comum e definição das indústrias de rede é o fato de que elas apresentam retornos crescentes de escala no consumo, comumente chamado de "efeitos de rede". A existência de externalidades de rede é a principal razão para a importância, crescimento e rentabilidade das indústrias de rede. Os efeitos de rede exposições mercado (ou externalidades de rede) quando o valor para um comprador de uma unidade extra é mais elevada quando estão mais unidades vendidas, tudo o resto é igual. (Jansen, 1996).

Uma das principais características das indústrias de rede está relacionada ao elevado grau de especificidade dos ativos de rede, Normalmente, os ativos de rede são capital intensivo que têm baixa reversibilidade em outras atividades econômicas. Esse é normalmente o caso dos ativos de transporte e distribuição de gás natural. Correljé (2004) observa que investimentos em ativos de produção, transporte e distribuição de gás natural requerem um elevado nível de investimentos, e uma vez realizados têm uma única e específica finalidade: produzir, transportar ou distribuir gás natural. 
Os sistemas de gás natural englobam as seguintes atividades: i) produção de gás; ii) transporte; iii) distribuição; e iv) comercialização. O segmento de produção envolve a exploração, o desenvolvimento e a produção de gás natural nas bacias sedimentares. A atividade de transporte corresponde ao transporte do combustível entre os campos produtores e os mercados consumidores.

Também os segmentos a montante e a jusante das redes de transporte e distribuição de gás natural são afetados pelas elevadas especificidades de ativos destes últimos, uma vez que produtores, transportadores, distribuidores e comerciantes passam a ter uma relação de mútua dependência, sendo esta fundamental para a efetiva consecução de investimentos de rede (JENSEN, 2004).

Sobre esta relação de dependência, Correljé (2004) afirma que cada lado tem que enfrentar o risco de que o outro lado pode eventualmente não cumprir o contrato ou que os preços poderão oscilar a níveis inaceitáveis. Para os produtores, a forma de volume implica em um risco no sentido de que novos investimentos na exploração e produção de tornar-se inútil, porque não teria para quem vender o gás que produzem. $\mathrm{O}$ risco de preço implica que devido à relação estreita entre eles, produtores ou consumidores estão para exercer pressão sobre o outro lado para vender gás a preços muito altos ou muito baixos.

Devido a sua característica desse combustível de encontrar-se no estado gasoso na temperatura e pressão ambiente, o transporte de gás natural traz desafios tecnológicos a serem superados. De acordo com Chandra (2006), o custo de transporte de uma "unidade de energia" presente no gás natural, por meio de um gasoduto terrestre, é de três a cinco vezes maiores que o equivalente em energia ao custo do transporte de petróleo bruto. Caso o gasoduto seja offshore e de longa distância-acima de $3.000 \mathrm{~km}$, o custo de transportar gás natural pode chegar a vinte vezes o custo de se transportar petróleo.

A Figura 2, abaixo, apresenta a comparação dos custos de transporte destes energéticos, em dólares por barril equivalente de petróleo. 


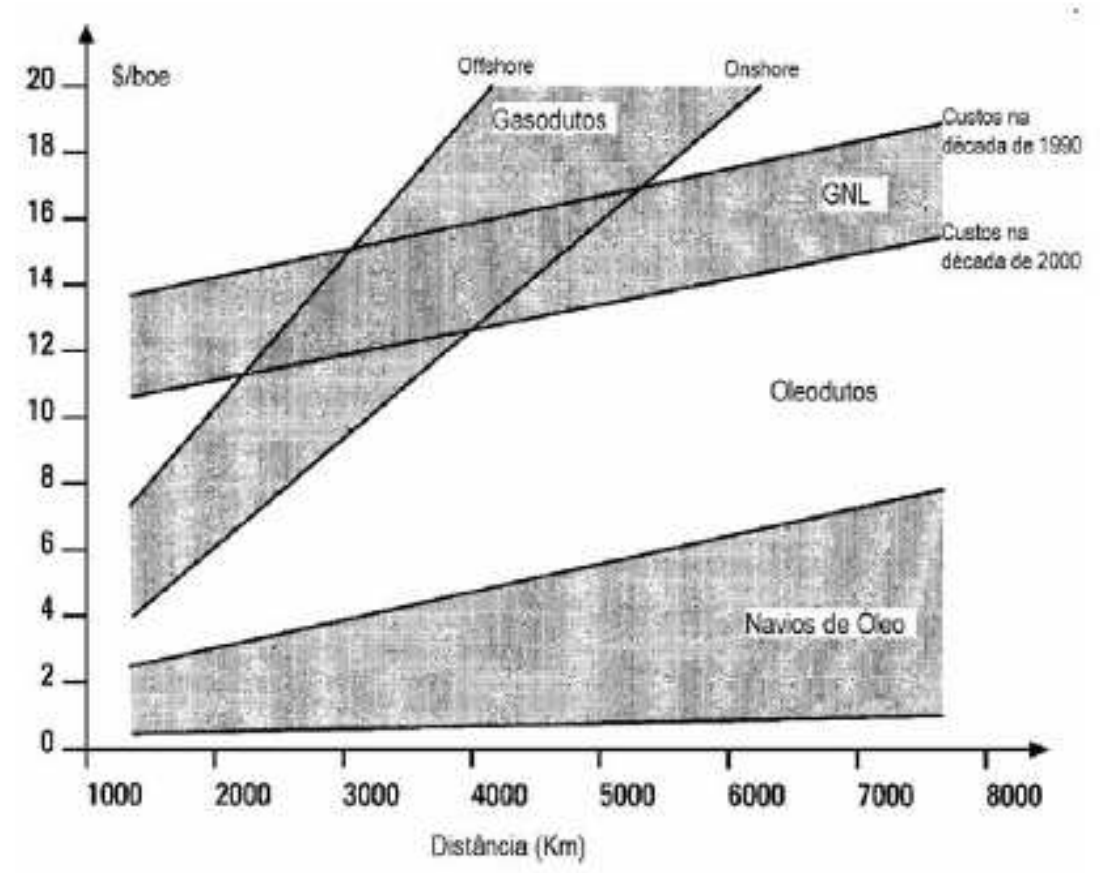

Figura 2 - Comparação entre os custos de transporte de petróleo e de gás natural Fonte: CHANDRA (2006)

Portanto, um elemento fundamental para o desenvolvimento da indústria de gás natural foi a distância pela qual o gás natural tinha que ser transportado desde a produção até o consumo final, a qual foi crescendo à medida que as tecnologias de transporte de gás natural foram se desenvolvendo. Um princípio fundamental que norteou $\mathrm{o}$ desenvolvimento inicial da indústria gasífera em diversas partes do mundo foi o fato de que em função dos elevados custos do transporte do hidrocarboneto, o efetivo desenvolvimento das reservas de gás natural e uma eventual produção deveriam ocorrer o mais próximo possível do mercado consumidor (CHANDRA, 2006).

A conjugação destes elementos e fundamental para entender o desenvolvimento histórico da indústria por meio da construção de gasodutos de transporte de gás natural, que ligavam as regiões produtoras aos mercados consumidores (FOSS, 2005). O crescimento da indústria, portanto, se deu mediante a constituição de mercados de gás natural regionalizados primeiramente locais e, posteriormente, regionais.

A elevada especificidade dos ativos de transporte de gás natural e o alto custo desses ativos de capital intensivos tornavam necessária a existência de mecanismos de garantia para que investimentos fossem efetivamente realizados. Proliferaram-se, portanto, os 
contratos de longo prazo com a presença de cláusulas que garantiam o retorno do investimento, como as cláusulas de take or pay (ToP) e ship or pay (SoP) (JENSEN, 2004). Take or pay e um acordo entre duas partes em que se concorde comprar determinados bens ou serviços de outra parte em uma determinada data ou a pagar por eles, mesmo que não necessite do bem ou suprimento nessa data. Um contrato de takeor-pay fornece receita garantida para o vendedor, mesmo que o comprador decida não comprar os bens ou serviços (SZKLO, 2007).

Uma característica definidora de projetos no setor de energia é que eles frequentemente requerem investimentos de capital iniciais significativos sobre parte dos produtores para a exploração, concepção e construção das instalações.

Isso abre a porta para o que alguns economistas chamam de o "hold up problema": alguns compradores podem ter um incentivo para tirar proveito dos investimentos feitos pelo vendedor (que reforçam a posição de barganha do comprador, uma vez que estes investimentos têm pouco valor para outros usos) para aumentar, assim, a sua parte dos lucros gerados. Para ajudar lidar com este problema, os compradores e vendedores entram em contratos de longo prazo, os quais se destinam a garantir uma corrente de receitas para o vendedor em termos pré-determinados.

De acordo com Foss (2005), dessa forma, o vendedor assume um grau de risco de preço ao longo da vidado contrato. Vendedores, por outro lado, ter cometido somas substanciais para o projeto - muitas vezes apoiado por bancos cujo único recurso é o projeto em si - exigem garantias quanto à renda em curso. Por isso, eles pedem que os compradores assumam riscos de abastecimento através da imposição de um contrato de take-or-pay. O objetivo é assegurar que o vendedor recebe pelo menos um fluxo de receitas nível mínimo definido no início do contrato.

Deve-se destacar que o gás natural possui poucos nichos de mercado cativo, podendo ser facilmente substituível em várias aplicações. Esse risco de mercado pelo lado da demanda resulta na comum aplicação do mecanismo de netback pricing para a formação do preço do gás natural. Ou seja, na definição dos preços do gás são considerados os preços de seus substitutos (CASTANEDA, 2004). O netback pricing e uma fórmula de precificação com base no preço efetivo ao produtor ou vendedor em um local específico 
ou ponto definido. Por exemplo, o gás natural liquefeito (GNL) preços netback pode ser determinado pelo preço do gás natural no mercado de destinos de mercado menos o custo de transporte por dutos, regaseificação, transporte fluvial e liquefação. O petróleo bruto pode ter um preço sobre o valor de seus produtos refinados, ou gás natural com preço baseado no preço de mercado de gás natural, menos o custo para a entrega a partir do ponto definido para o local.

Em síntese, existe uma rigidez no custo de transporte do gás natural que frequentemente ultrapassa supera o de outros energéticos que lhe são substitutos, como o óleo combustível, petróleo e energia elétrica que possui uma rede de distribuição do bem estabelecida.

Dessa maneira, a evolução da indústria e o comércio internacional do energético foram historicamente baseados na construção de grandes dutos de transporte com rígidos esquemas contratuais de longo prazo (FOSS, 2005).

Foram, portanto, construídas redes de transporte entre campos produtores e mercados consumidores cujas distâncias não eram muito elevadas, resultando no desenvolvimento de mercados regionalizados com características peculiares e uma lógica própria de funcionamento em cada um deles (CORRELJÉ, 2004).

Na Europa, construíram-se redes de transporte de gás natural por meio de dutos, ligando o principal país produtor do hidrocarboneto, a ex-União Soviética, aos principais mercados consumidores na Europa Ocidental. Posteriormente, foram também construídos dutos de transporte de gás natural entre o norte da África e o continente europeu, via Espanha e Itália. Foi desenvolvido um sistema internacional de transporte de gasodutos, regido por uma série de arranjos entre os países produtores e demandantes do gás natural (CASTANEDA, 2004).

O sistema de interligação dos EUA foi caracterizado pela predominância de firmas privadas regulamentadas pelos estados. Na América do Sul, inicialmente foram feitas conexões entre Argentina (principal consumidor de gás natural da região) e a Bolívia e entre a Argentina e o Chile. Em 1999, o Brasil também se conectou, por meio de gasodutos, com a Bolívia e com a Argentina (KIM, 2006). 
Diferentemente dos casos citados anteriormente, na Ásia devido a ausência de reservas de gás natural e em função da necessidade do abastecimento daquela região, optou-se pela utilização do transporte do gás natural liquefeito - GNL. Com redes de transportes constituídas entre países, houve a possibilidade de comercialização internacional do energético e foram criados mercados regionais significativos, mas isolados uns dos outros: o mercado europeu, o norte-americano e o asiático, como podem ser visto na Figura 3.

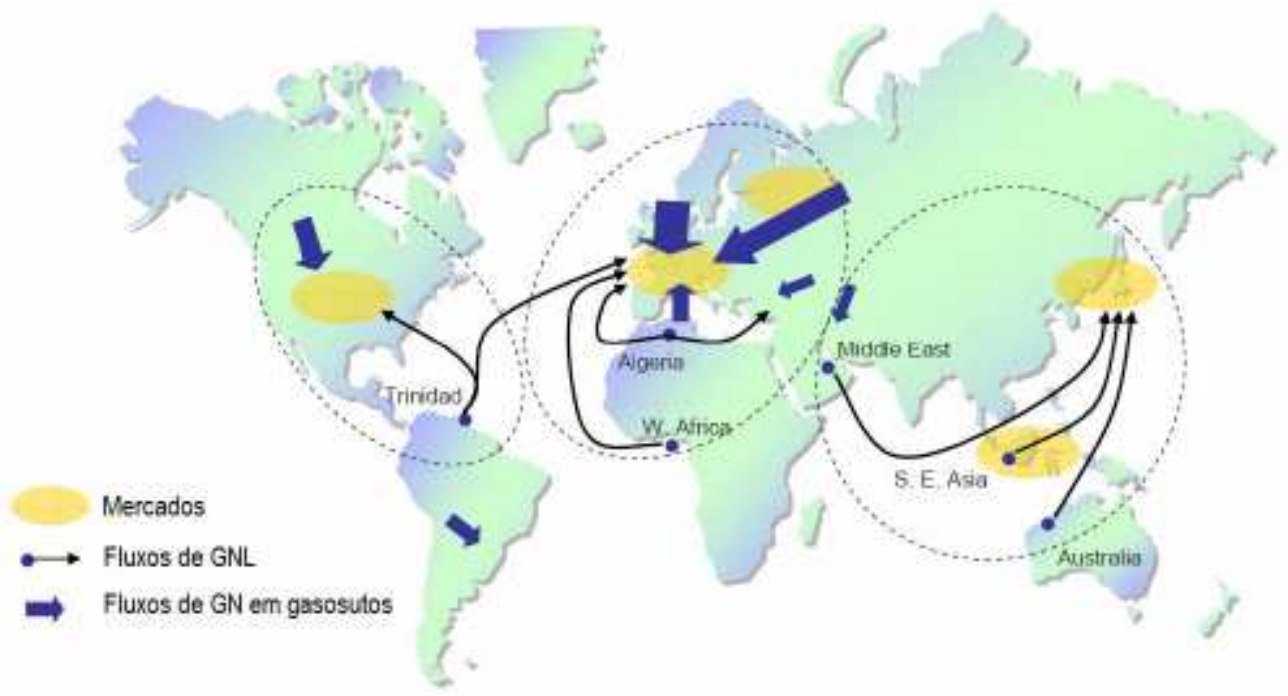

Figura 3 - Mercados de gás natural

Fonte: (KIM, 2006)

As próximas seções apresentam a evolução histórica dos três principais mercados de gás natural, como também a evolução do desenvolvimento do mercado de gás natural na América do Sul, que tem na Argentina o principal país consumidor.

Cada um desses mercados funcionou historicamente de forma independente e com uma lógica de formação de preços diferenciada. 


\subsection{Mercado de Gás Natural na América do Norte}

De acordo com Foss (2004) nos primeiros anos da indústria de gás natural nos EUA, a construção e operação de sistemas de distribuição de gás natural foram em torno de depósitos concentrados locais de gás natural. Ocorrência natural de gás natural foi descoberta e identificada nos EUA, já em 1626, por exploradores franceses. Em 1821, William Hart cavou a primeira bem sucedida bem gás natural em os EUA em Fredonia, Nova York. Cidades e vilas que estavam perto do início descobertas de gás natural no final de 1800 eram frequentemente centros de intensa atividade competitiva como as empresas se esforçaram para construir sistemas concorrentes competir.

Em 1859 o Coronel Drake descobriu petróleo na Pensilvânia, teve também como consequência a descoberta de gás natural, uma vez que os dois hidrocarbonetos normalmente são encontrados associados. O gás natural descoberto no leste da Pensilvânia era comercializado a consumidores regionais. Portanto, na visão de Castaneda (2004), a descoberta de Drake deu início não apenas à indústria moderna de petróleo, mas também à indústria moderna de gás natural.

Segundo o mesmo autor (Castaneda 2004), em meados do século XIX, apenas fábricas ou cidades localizadas muito perto de um poço de gás natural poderia utilizar o combustível. A dificuldade de armazenamento e transporte por longas distâncias faziam com que sua utilização fosse limitada.

Esta dificuldade de acondicionamento e transporte do gás natural não acontecia no caso do gás manufaturado a partir do carvão e, por isso, desde o início do século XIX a indústria estadunidense de gás manufaturado já se espalhara pelo país. Ainda no século XIX várias cidades dos Estados Unidos possuíam plantas para a produção de gás manufaturado e de sistemas locais de distribuição para residências e para iluminação: Baltimore (1816), Nova York (1825), Boston (1829), Louisville (1832), Nova Orleans (1835), Filadélfia (1836), Cincinatti (1843), St. Louis (1846), Chicago (1849), São Francisco (1854), Kansas City (1867), Los Angeles (1867), Mineápolis (1871) e Seattle (1871). 
Durante a maior parte do século XIX, o gás natural foi utilizado quase exclusivamente como uma fonte de luz, a ordem em 1885, invenção do que hoje é conhecido como o bico de Bunsen de Robert Bunsen abriu vastas novas oportunidades para utilizar o gás natural. Uma vez que pipelines efetivos começaram a ser construído no século XX, o uso de gás natural expandiu para aquecimento doméstico e de cozinha, aparelhos como aquecedores de água e faixas de forno, plantas de fabricação e processamento.

De acordo com Kim (2006), junto com melhorias nos materiais e técnicas de construção do gasoduto, compressor de gás e máquinas de amaragem tecnologia também melhorou. Dutos de longa distância tornou-se um segmento significativo da indústria do gás começando na década de 1920. Estas novas tecnologias tornaram possível, pela primeira vez o transporte de gás natural aos mercados do Centro-Oeste do sudoeste. Entre meados de 1920 e meados de 1930, a combinação de produção de gás natural do sudoeste abundante e barata.

Foss (2004) destaca que a descoberta de grandes depósitos de gás natural no Texas e Oklahoma mudou fundamentalmente as indústrias de gás natural dos Estados Unidos. As empresas começaram a construídas condutas de longa distância para transportar gás natural do sudoeste dos Estados Unidos para Noroeste e Centro-Oeste, onde era necessário de gás para aquecimento no inverno com a possibilidade de transportar gás natural entre as fronteiras dos estados iniciou-se a disputa entre os estados envolvidos nas transações para definir a jurisdição regulatória.

No final da década de 1920, quatro companhias dominavam a indústria de gás natural nos Estados Unidos e buscavam também controlar o transporte interestadual do energético: i) Columbia Gas; ii) Standard Oil of New Jersey; iii) Henry Doherty's Cities Service; e iv) Samuel Insull's Insull \& Sons, este último o maior dos conglomerados de utilities dos EUA na década de 1920. 


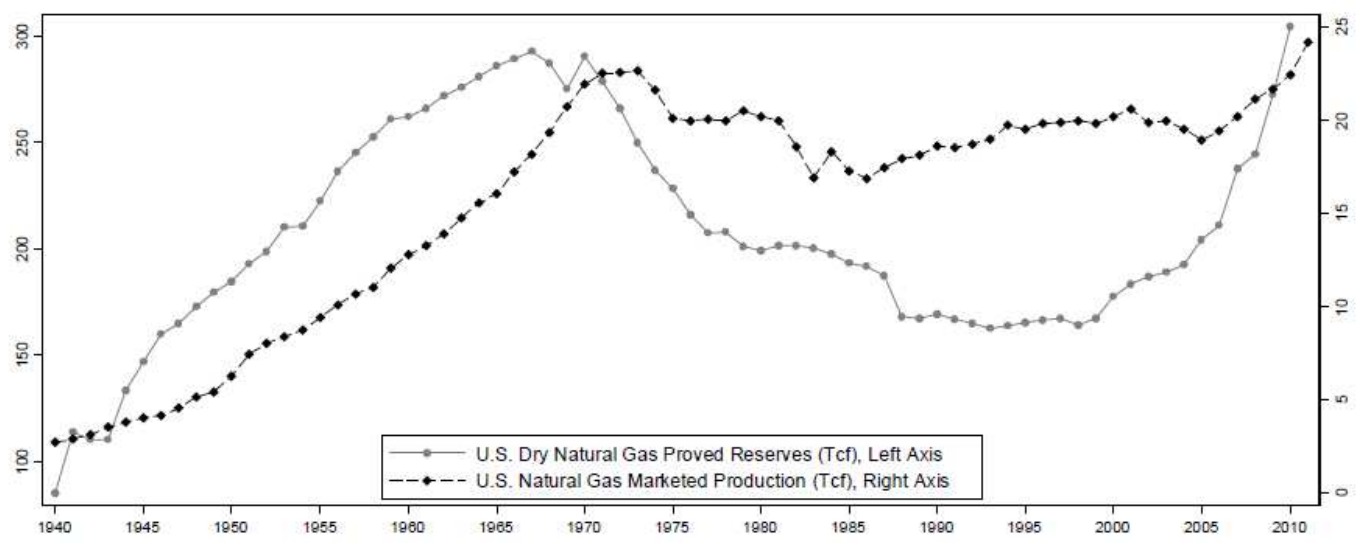

Figura 4 - EUA reserva de mercado e produção a partir de 1940 Fonte: EIA/DOE (2011)

Paralelamente, pelo lado da oferta, o país apresentava um incremento dos volumes ofertados. A conjugação da retração na demanda e do aumento da produção doméstica produziu um excesso de oferta no início da década de 1980, o qual, como antes asseverado, ficou conhecido como a "bolha de gás" do mercado estadunidense (LEE, 2004).

Diante dessa conjuntura de oferta e grande quantidade de gás contratada por parte dos gasodutos interestaduais, estes procuraram mercados para a colocação desse gás, dando início aos mercados spot de gás natural nos EUA. (MICHAELS et al., 1995).

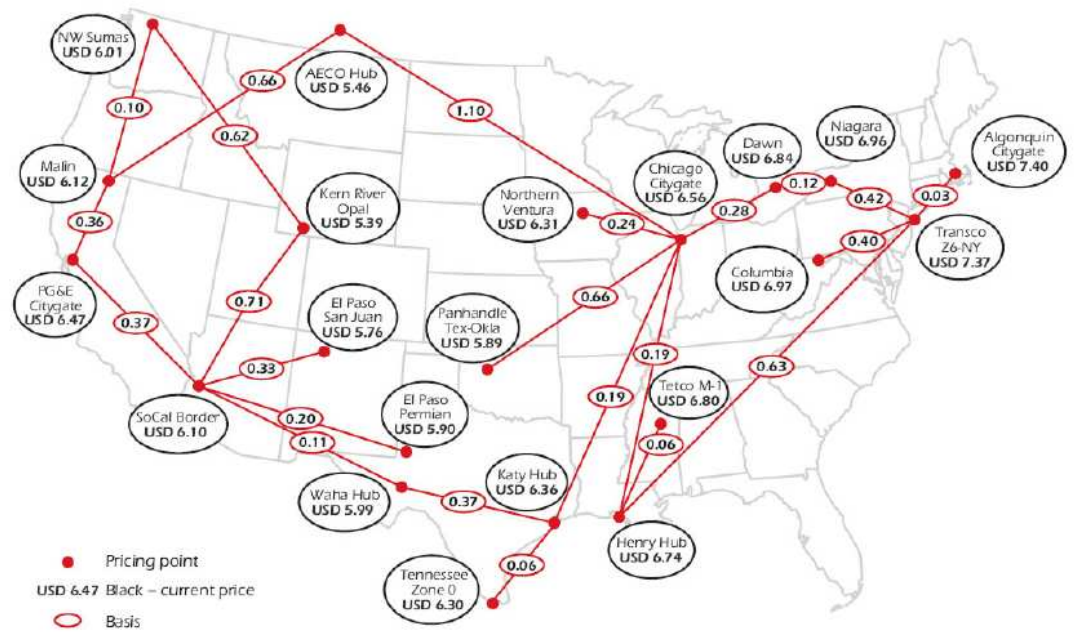

Figura 5 - Mapa de rede de gasodutos dos EUA

Fonte: Internacional Energy Agency (IEA 2012) 
O gás excedente foi despejado para o mercado local a preço corrente. Vendas à vista levaram não só a encontrar uma saída aos produtores, também os compradores de atacado poderiam comprar a um preço muito mais baixo. Como resultado, os mercados à vista começaram a se desenvolver desde o início da década de 1980 nos Estados Unidos.

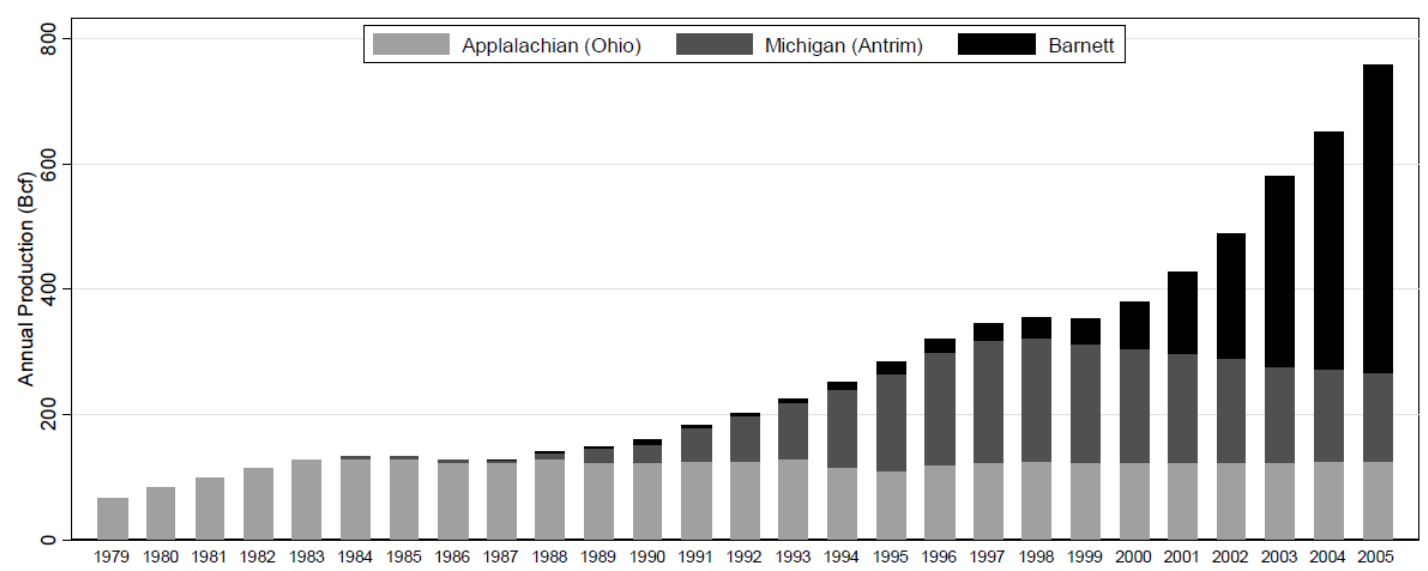

Figura 6 - Evolução do consumo de gás natural nos EUA (1979-2025) (em bilhões de pés cúbicos)

Fonte: Curtis, 2009

Até a década de 1980, os mercados interligados dos EUA e do Canadá operavam baseados em contratos de longo prazo. Entretanto, como apresentado, as décadas de 1980 e 1990 testemunharam a liberação dos mercados de gás natural na América do Norte, com o unbundling das atividades de rede. Os preços passaram a ser definidos pela interação entre a oferta e a demanda de gás em um determinado momento e local e não mais pelo preço do petróleo (IEA, 2006). O unbundling ocorre quando a desregulamentação resultou em concorrência de preços, e passa a ser necessário oferecer e o preço de cada produto separadamente ou de forma independente.

De acordo com relatório da Internacional Energy Agency (IEA 2010), nos Estados Unidos e Canadá, as reformas regulatórias da década de 1980 e 1990 promoveram centros de mercado e hubs, onde o transporte e armazenamento de gás são negociados entre um grupo diversificado de participantes do mercado. 
Na figura 7 é possível observar como o mercado de gás natural dos EUA é interligado, possibilitando o comércio e utilização através de diversos compradores e vendedores conectados por meio de redes de transporte. O gás natural é transacionado nos hubs, que são os pontos de entroncamento de gasodutos de transporte em que o gás é entregue pelo fornecedor.

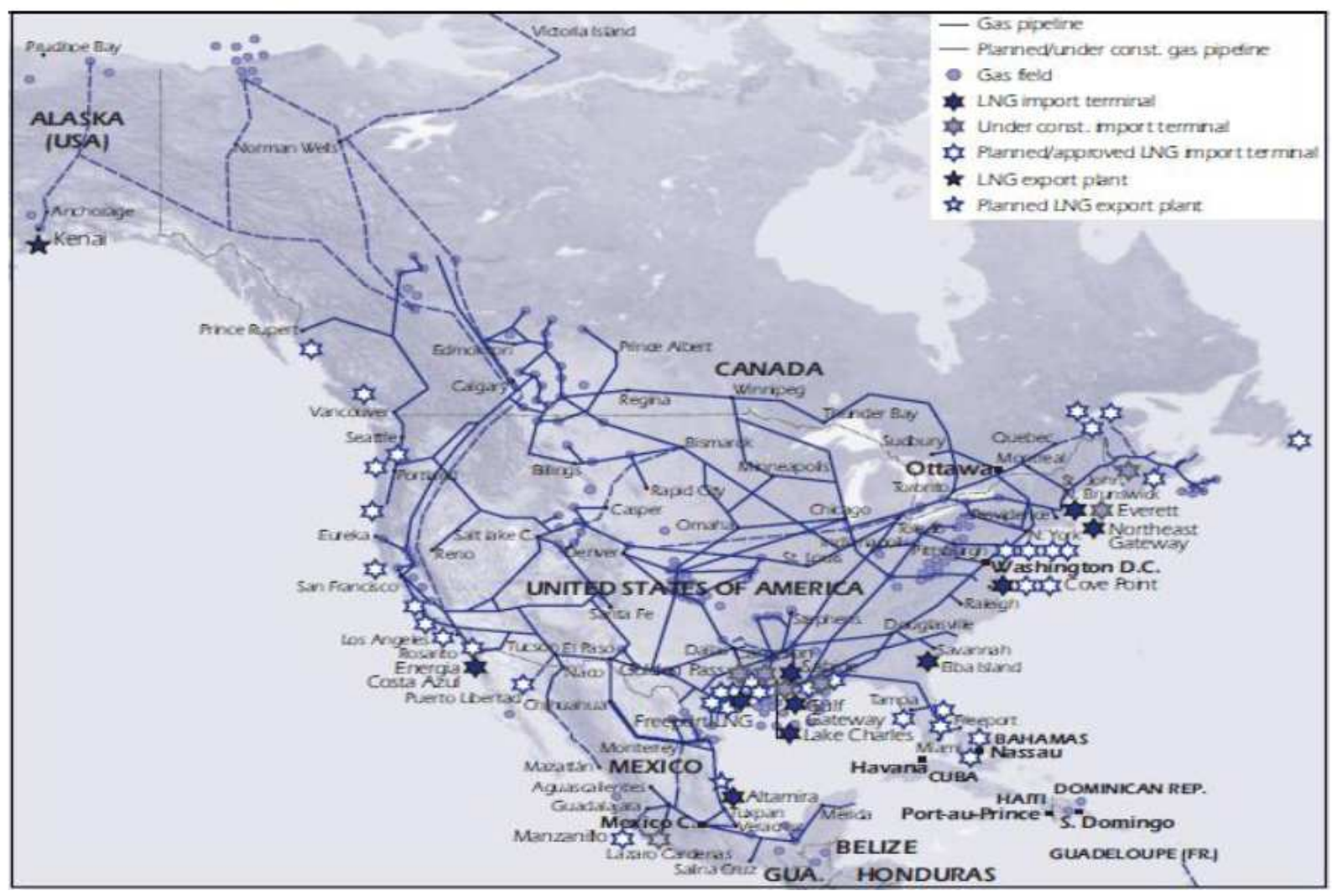

Figura 7 - Mapa de rede de gasodutos dos EUA

Fonte: Natural Gas Market Review (2009). International Energy Agency - IEA

\subsubsection{Regulação nos EUA}

A regulação do gás natural remonta aos primórdios da indústria nos EUA. Nos primeiros anos da indústria (meados de 1800). A teoria econômica dita que uma empresa em uma posição de monopólio com controle total sobre o mercado devido à falta de concorrência, poderia tirar vantagem de sua posição e, dessa forma, haveria o risco de preços excessivamente altos serem praticados. A solução a partir dos pontos de vista dos governos locais foi de regular a monopólios naturais, e definir um regulamento para impedir abuso de poder. 
No início de 1900, nos EUA, o gás natural passou a ser fornecido ao longo de fronteiras municipais. Os primeiros oleodutos que transportam gás interestadual começaram de a percorrer cidades. Entretanto, logo as fronteiras passaram atingir outros estados, e esta nova mobilidade de gás natural significou que os governos municipais não poderiam seguir supervisionando a cadeia de distribuição de gás natural integral. Em resposta a isso, os governos estaduais intervieram para regular o novo mercado de gás natural interestadual, e determinou as taxas que poderiam ser cobradas pelas distribuidoras de gás (ROSS 2005).

Com o advento da tecnologia que permitiu o transporte de longa distância de gás natural através de gasodutos interestaduais, novos obstáculos regulatórios surgiram. Da mesma forma que os governos municipais que não foram incapazes de regular distribuição de gás natural mais extenso do que suas áreas de jurisdição, os governos estaduais também não o fizeram. Entre 1911 e 1928 vários estados tentaram consolidar a regulamentação da supervisão de dutos interestaduais. No entanto, em uma série de decisões, o Supremo Tribunal dos EUA decidiu que tal supervisão estadual de dutos violou a cláusula interestadual do comércio constituição dos EUA (MICHAELS 1995).

Estas células, conhecidas como 'Suprema Corte Comércio Cláusula, essencialmente afirmou que as empresas de gasodutos interestaduais estavam regulando além do poder do governo estadual. Sem quaisquer leis federais que tratam de dutos interestaduais, a decisão levou a uma não regulamentação dos dutos interestaduais, deixando uma lacuna para que a atividade fosse exercida de forma eficiente entre os agentes.

Entretanto, devido à preocupação com o poder de monopólio dos oleodutos interestaduais, bem como o conglomerado de indústria, o governo federal achou por bem intervir. Em 1935, a Comissão Federal de Comércio divulgou um relatório delineando preocupação com o poder de mercado que possa ser exercida por empresas de energia elétrica e de gás natural. A esta altura, mais de um quarto da rede de gasoduto interestadual de propriedade tinha apenas 11 holdings; essas empresas controlavam uma parte significativa da produção de gás, distribuição e geração de eletricidade (MICHAELS 1995). 
Em resposta a este relatório, em 1935 o congresso americano aprovou a Lei de Utilidade Pública Holding Company para limitar a capacidade das empresas de utilidade pública de eventualment ganhar vantagem indevida sobre um mercado. No entanto, esta lei não cobria a regulamentação das vendas de gás interestaduais (SMITH, 2010).

Em 1938, o governo federal se envolveu diretamente na regulação do gás natural interestadual com a aprovação da Lei do Gás Natural (NGA). Este ato sela o primeiro envolvimento real do governo federal nas tarifas cobradas pelas empresas de transporte de gás interestaduais. Essencialmente, o NGA deu à Comissão Federal de Energia (FPC), tudo que tinha sido criado em 1920 com a aprovação da Lei de Energia Água Federal.

A supervisão regulamentar NGA, entretanto, não especificou a vendas de gás natural dos gasodutos aos produtores: os preços diretos no poço não foram regulamentados. No entanto, em casos da Suprema Corte caindo no início dos anos 1940, determinou-se que foi os preços de cabeça de poço sujeito a fiscalização federal, se a venda produtor e o pipeline de compra eram empresas afiliadas. No entanto, a FPC sustentou que, se o produtor de gás natural e gasoduto não afiliados.

A justificativa para a passagem do NGA foi preocupação com a forte concentração da indústria de gás natural, e as tendências monopolistas de dutos interestaduais para carregar superiores aos preços competitivos devido ao seu poder de mercado. Entretanto, o NGA necessário que as taxas "justas e razoáveis" para condutas de longa distância ser executadas, ele não especificou qualquer regulamentação especial de preços (TONERO, 2007).

Em 1954, porém, esse tudo mudou com a decisão da Suprema Corte em Phillips Petroleum Co. Wisconsin. Nessa decisão, a Suprema Corte decidiu que os produtores de gás natural vendido de gás natural em gasodutos interestaduais caíram sob a classificação de empresas de gás natural, no NGA, e estavam sujeitos a controle regulamentar pela FPC. Isso significava que os preços de todos os produtores de gás natural vendido no mercado interestadual - seriam regulamentados da mesma forma que o gás natural vendida por dutos interestaduais. 
A decisão da Suprema Corte de Phillips teve um efeito de longo alcance sobre a indústria de gás natural. Na regulação dos preços no poço, a FPC, instituiu um serviço de custo de tradicional de fazer a determinação da taxa. Este sistema de fixação das taxas de contado com o custo da prestação do serviço, e não o valor desse serviço mercado. Isso significava que os preços estavam fixados para permitir às cobrir os altos os custos reais de produção de gás natural, além de um lucro justo (KIM, 2004).

O grande número de produtores de gás significava que foi um fardo administrativo extremo para a FPC. Na pratica, cada um permaneceu com suas próprias dificuldades, até que, finalmente, o controle de preços poço culminou com a escassez. De 1954 a 1960, a FPC tentou lidar com produtores e suas taxas em uma base individual. Cada produtor foi tratado como uma utilidade pública individual, e as taxas definidas com base em custo dos produtores do serviço. Por exemplo, em 1959 , havia 1.265 aplicativos separados para comentários aumentos da taxa.

Devido a este atraso enorme, a FPC em 1960, decidiu criar taxas com base em áreas geográficas. Os EUA foram divididos em cinco regiões produtoras independentes, e as taxas foram estabelecidas para todos os poços em uma determinada região. A FPC definira os preços máximos baseado na média de preços dos contratos de gás natural pagos caindo em 1959-1960 para uma determinada área (BENNET, 2004).

Entretanto, o processo para determinar as taxas de toda a área levou junto muito mais dificuldade do que fora antecipado, e em 1970, a taxa de HAD foi definida para apenas duas das cinco zonas de produção. Para piorar a situação, para a maioria das áreas, os preços essencialmente foram congelados a níveis de 1959. O problema com a determinação das taxas para uma área especial com base em metodologias de custo de serviço que existia muitos poços, era o fato de haver custos muito diferentes na geração.

Em 1974 a FPC havia determinado que área ampla preços fosse inviável. Na tentativa de encontrar um sistema de regulação de preços do gás. Percebendo que os preços máximos anteriores, com base na abordagem de custo de serviços, foram muito menores do que o valor do gás natural interestadual de mercado, a FPC estabeleceu um preço nacional teto de US $\$ 0,42$ por milhão de pés cúbicos (mcf) de gás natural (FOSS, 2005). 
Todos os três sistemas de teses de controle de preços discutido acima teve efeitos desastrosos sobre o mercado de gás natural nos Estados Unidos. Os preços máximos artificialmente baixos que tinham estabelecidos desde 1954 teve um impacto no mercado, chegando ate o final dos anos 1960 e 1970. Porque as taxas fixadas para o gás natural a seguir foram o valor do gás natural no mercado, a demanda aumentou. Isto combinado com o preço do petróleo surge experiente caindo sobre a crise da OPEP na década de 1970 fez gás natural combustível mais atraente (KIM, 2004).

No entanto, ao mesmo tempo, havia pouco incentivo para os produtores de gás natural para dedicar o dinheiro necessário para a exploração de gás natural. O preço de venda do gás natural era tão baixo, simplesmente não conseguia pagar os custos da cadeia de produção. Os produtores viam pouco incentivo para procurar novas reservas. Enquanto o preço pelo qual eles poderiam vender gás interestadual foi fixado, os custos de desenvolvimento para novas reservas eram imprevisíveis. Produtores tinham pouca razão para se engajar na exploração de novas reservas que custariam mais para serem encontradas do que eles poderiam obter com o produto vendido (FOSS, 2005).

Em 1976 e 1977 Muitas escolas e fábricas no Centro-Oeste foram obrigados a fechar devido a uma escassez de gás natural para executar suas instalações. Enquanto isso, nos estados produtores, Praticamente nenhuma falta foi sentida, devido à florescente mercado interestadual onde demanda por gás natural atingia níveis satisfatórios (KIM, 2004).

Em novembro de 1978, no auge da escassez de abastecimento de gás natural, o congresso americano aprovou a legislação conhecida como a Lei de Política de Gás Natural (NGPA), como parte de legislação mais ampla conhecida como a Lei Nacional de Energia (NEA). Percebendo que esses controles de preços que tinham sido colocados em prática para proteger os consumidores de preços monopólio potencial já tinha um círculo completo para prejudicar os consumidores na forma de escassez de gás natural, o governo federal, procurada pela NGPA, teve a incumbência de rever a regulamentação federal. Essencialmente, este ato teve três objetivos principais: (i) a criação de um mercado único do gás natural nacional; (ii) equalizar oferta com a demanda; (iii) estabelecer forças de mercado para o preço direto no poço de gás natural (FOSS, 2005). 


\subsection{Mercado de Gás Natural na Europa Continental}

A Europa continental passou a desenvolver sua indústria de gás natural de forma tardia, somente a partir da II Guerra Mundial. Devido a crescente importância do petróleo nas economias, principalmente dos EUA, os governos europeus iniciaram esforços para a exploração do petróleo, fato que acabou resultando na descoberta também de campos de gás natural, uma vez que petróleo e gás tem a característica de exploração associada (FOSS, 2004).

Em 1959, foram descobertas reservas de gás na Holanda, marcando o começo do desenvolvimento dessa indústria na Europa continental A exploração das reservas de Groningen - Holanda permitiu o desenvolvimento, ao longo da década de 1960 da indústria de gás natural em outros países da Europa continental como a Alemanha, a Bélgica, a França, a Suíça e a Itália.

O campo de Groningen possui importância notória para a indústria de gás natural na Europa continental. A sua localização seria o primeiro destaque, uma vez que em um raio de $482 \mathrm{~km}$ deste campo produtor estão localizadas a maior parte das populações da Alemanha, França e toda a Holanda e a Bélgica. O norte da Itália dista $966 \mathrm{~km}$ de Groningen. A segunda característica desse campo a ser destacada é o fato de ele ser um campo de gás não associado localizado em terra, portanto sua produção poderia ser adaptável quantidade demandada em certos limites (PEEBLES, 1980).

O campo da Holanda teve o início de sua produção em 1964. As exportações holandesas foram tão significativas que afetaram a economia doméstica de tal forma que ensejaram a chamada doença holandesa, ou seja, as receitas de exportação do gás natural foram tão significativas que resultaram na apreciação cambial real da moeda nacional, tornando a indústria doméstica menos competitiva (Usui, 1998; Hjort, 2006).

A maior parte dos contratos de exportação do gás natural da Holanda, foi firmada na década de 1960, com prazos que poderiam variar de 20 a 25 anos, a preços fixos na fronteira entre os países, num período em que os preços da energia caíam e que a oferta 
era abundante. Nestes contratos, também ficavam estabelecidos que os aumentos de preços deveriam ser negociados entre comprador e vendedor do insumo. Entretanto, depois de 1973 com o choque do petróleo, esse tipo de sistema de preços autorregulado foi descontinuado, e de comum acordo, o preço do gás natural passou a ser atrelado ao preço do petróleo (IEA, 2002).

Apesar de um pouco mais distante do mercado europeu, o aproveitamento das reservas da Rússia, (então União das Repúblicas Socialistas Soviéticas) também foram de extrema importância para o desenvolvimento e a efetiva consolidação deste mercado. $\mathrm{O}$ uso do gás natural na ex-URSS data da década de 1920, em sua maior parte de gás associado (PEEBLES, 1980).

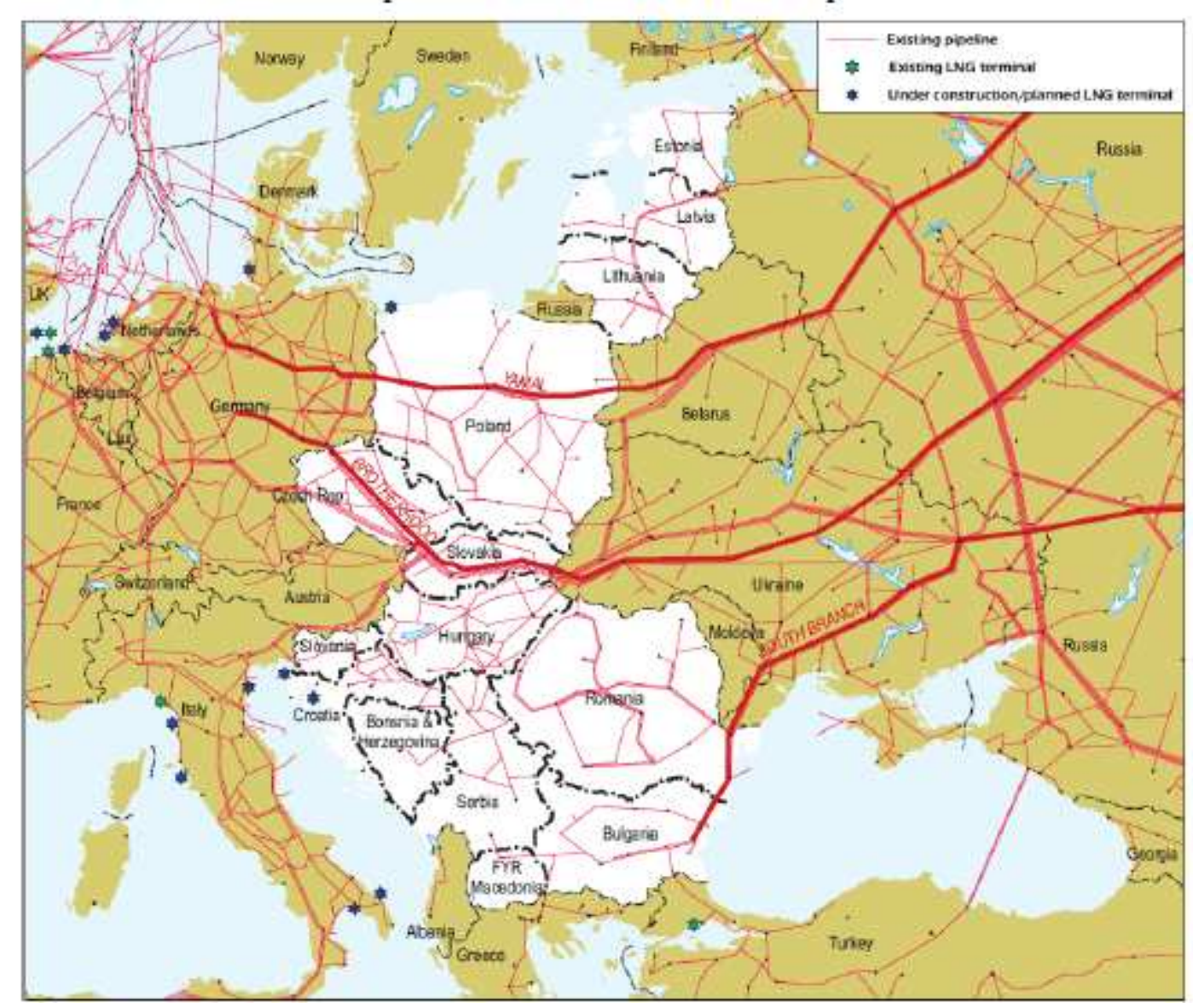

Figura 8 - Principais linhas de conexão de gás natural na europa continental Fonte: Petroleum Economist, IEA (2010)

Apenas da década de 1950, o governo decidiu concentrar esforços para a utilização do gás natural tão abundante encontrado na região, reconhecendo sua importância para o 
desenvolvimento industrial da então URSS. Em 1955, aproximadamente 100 cidades já tinham a chance de utilizar o gás natural como suprimento energético, a maior parte delas em regiões próximas aos centros produtores da Rússia e da Ucrânia. Até este momento, a era de construção de gasodutos de longa distância ainda não tinha ainda iniciado (PEEBLES, 1980).

Em 1956 um gasoduto de $1254 \mathrm{~km}$, de 28 polegadas, ligando Stavropol a Moscou entrou em operação, se caracterizando como a primeira linha de longa distância da Europa A partir de então, malhas de transporte de gás natural ligando a produção ao consumo em toda a ex-URSS foi expandida com grande velocidade. (FOSS, 2005).

Em relação às trocas internacionais de gás natural, a Rússia exporta gás natural desde 1940, o primeiro registro de exportação de gás natural foi a venda para a Polônia, em 1946. As primeiras transações internacionais do produto foram com a parte oriental da Europa e posteriormente o país também passou a exportar o hidrocarboneto para a parte ocidental europeia (KIM, 2004).

Outra experiência na produção de gás natural no continente ocorreu na Itália. No início da década de 1960 a AGIP, na busca por petróleo, encontrou gás natural no norte da Itália (no Vale do Pó) e a companhia começou a produção do hidrocarboneto para o atendimento a pequenas indústrias No ano de 1965 a Itália era o maior produtor e também consumidor de gás natural da Europa Ocidental, quando o energético já correspondia a $10 \%$ da demanda total de energia primária do país. À época a Inglaterra, a Espanha ou a Alemanha sequer utilizavam o hidrocarboneto (HAYES, 2004).

Grandes reservatórios no Vale do Pó permitiram o estabelecimento de instalações de dutos para alcançar os principais fábricas no norte da Itália. Essa escolha tem determinado círculo virtuoso de crescimento: as principais empresas italianas expandiram enormemente na década de 1950 e 1960. Os altos lucros das vendas de gás natural foram reinvestidos na exploração, produção, a expansão de gasodutos, bem como a aquisição de novos clientes. (POZZI, 2004). 
A elevação dos preços do petróleo na década de 1970 impulsionaram países como a Itália, a França e a Espanha a buscarem novas fontes de suprimento para o atendimento de sua demanda como uma alternativa para a diminuição da vulnerabilidade dos países com relação à oferta de gás natural, por meio da diversificação das suas fontes de suprimento (HAYES, 2004).

Neste contexto destaca-se a construção de dois importantes gasodutos que ligaram o norte da África ao continente europeu, um ligando o Marrocos à Espanha através do Estreito de Gibraltar e outro ligando a Tunísia à Itália, através da Sicília onde transportam gás natural produzido na Argélia. Destacam-se também duas plantas de liquefação na Argélia (para o fornecimento de gás natural liquefeito não apenas para os países banhados pelo Mediterrâneo, mas também para o mercado dos Estados Unidos) e a construção das quatro plantas de regaseificação na Espanha (em Barcelona - em 1968, Huelva - em 1988, Cartagena - em 1989 e Bilbao - em 2003), uma na Itália (Panigaglia - em 1971) e duas na França (Fos-sur-Mer - em 1972, próxima a Marseilles, e Montoirde-Bretagne - em 1980, próxima a Nantes).

Propostas para importar gás da Argélia, que remonta à década de 1960 usando imaginou existentes tecnologias GNL. Porém, os custos de GNL foram elevados e ENI encorajados a explorar a viabilidade de um gasoduto ligando a Itália com o Norte de África. Um estudo preliminar de viabilidade foi o realizado para o gasoduto submarino em 1969 seguido pelo primeiro levantamento estrada em 1970.

Propostas para importar gás da Argélia, que remonta à década de 1960 usando imaginou existentes tecnologias GNL. Porém, os custos de GNL foram elevados e ENI encorajados a explorar a viabilidade de um gasoduto ligando a Itália com o Norte de África. Um estudo preliminar de viabilidade foi o realizado para o gasoduto submarino em 1969 seguido pelo primeiro levantamento estrada em 1970 (HAYES, 2004).

A efetiva operação comercial da TransMed deu início em 1983. O acordo entre as estatais ENI, da Itália, e Sonatrech, da Argélia, culminou num contrato de fornecimento de gás natural por 25 anos. No que diz respeito aos preços a Argélia, membro da OPEP, adotou o mecanismo de netback pricing. 
Na década de 1970, muitos vendedores começam a amarrar os preços do gás para os custos de combustíveis substitutos, normalmente óleo combustível. Procuraram fórmulas de preços que refletissem os custos crescentes de combustíveis competem competindo (geralmente óleo combustível) nos mercados offtake (FOSS, 2005).

No caso específico da Espanha, atualmente um importante demandador de GNL, a primeira planta de regaseificação foi construída pela estatal gasífera do país, a ENAGAS, em 1969. Originalmente esta planta deveria receber GNL da Líbia, O contrato de venda de GNL da Líbia para a Espanha tinha prazo de 20 anos de duração, mas em função de atrasos nos investimentos de liquefação daquele país, foi a Argélia a responsável pela entrega do primeiro carregamento de GNL para a Espanha, em 1969 (PEEBLES, 1980).

A Argélia, por meio de sua companhia estatal, a Sonatrach, também manteve negociações, ao longo de toda a década de 1970, com a Espanha e a França para o fornecimento de gás natural. Na realidade, a ideia de construir um gasoduto para levar gás natural da Argélia para a França e a Espanha teve início no princípio da década de 1960. Foram consideradas tanto as opções de entrega por meio de gasodutos (em duas diferentes rotas), quanto por meio de navios metaneiros, com gás natural sob a forma liquefeita (HAYES, 2004).

Em novembro de 1973 escolheu-se a rota que saía da Argélia, passava pelo Marrocos e cruzava o Mediterrâneo pelo Estreito de Gibraltar, chegando à Espanha. A companhia proprietária do duto seria um consórcio formado entre as estatais dos três países: a Sonatrach, da Argélia (com 50\% de participação), a espanhola ENAGAS com $25 \%$ e a francesa GdF com $25 \%$.

Entretanto, em função das tensões políticas entre Argélia e Marrocos, estes países envolveram-se em disputas com relação à determinação da fronteira desde a independência da Argélia, em 1962, o que levou ao conflito armado no ano seguinte. Também a Espanha mantinha tensas relações com o Marrocos em função da ocupação espanhola no território do Saara Oriental que compreendia o sul de Marrocos (HAYES, 2004). 
Correljé (2004) destaca que um oleoduto de exportação de gás natural abrangendo as fronteiras internacionais e águas profundas do oceano era uma empresa política, econômica e técnica extremamente complexam no momento foram propostos projetos de tese em 1970. Rotas de pipelines da Argélia à Itália e da Argélia à Espanha os países de trânsito envolvido, maciço novos investimentos e desafios técnicos da postura gasodutos submarinos. De GNL, no entanto, fez evitar negociações dificuldade com os países de trânsito (Tunísia ou Marrocos) e mais escalável foi, então, as alternativas de dutos.

Diante deste contexto, a ENAGAS passou a ver o GNL como a única fonte viável de incremento no suprimento de gás natural para o país. Desta forma, em 1975 a companhia assinou com a Sonatrach um contrato de duração de 25 anos, com a presença "das típicas e rígidas cláusulas de take-or-pay comuns à época e com a indexação de preços a uma cesta de óleos" (HAYES, 2004).

Apenas a partir de meados da década de 1990 o governo espanhol passou a ter condições de estimular o desenvolvimento do mercado de gás natural no país. A abertura do setor elétrico espanhol permitiu novos investimentos no setor energético do país, sobretudo nas plantas de geração elétrica a gás natural. Com o apoio da União Europeia o projeto da construção do duto ligando o sul da Espanha ao norte de África foi retomado. Em 1996 o gasoduto que liga Marrocos à Espanha (o Gaz MaghrebEurope) entrou em operação comercial, fornecendo gás natural de origem argelina para Espanha e Portugal (HAYES, 2004).

De acordo com Correljé (2004), na Europa continental, as empresas transportadoras e as empresas locais de distribuição receberam o monopólio legal para a exploração das atividades de transporte e distribuição de gás natural, destacando-se a companhia francesa (Gaz de France - GdF Suez), a italiana ENI. Fato que merece ser ressaltado, é que na Europa continental, diferentemente do que aconteceu nos EUA, onde o desenvolvimento da indústria de gás natural foi calcado na constituição de empresas privadas, o desenvolvimento da indústria foi ancorado pela participação de empresas criadas pelos governos nos países locais. 
Segundo Correljé (2004), por meio de agrupamento de concessões, a propriedade pública, planejamento indicativo, e os preços administrados, os produtores e os distribuidores eram para coordenar a compra e os volumes de vendas e preços de gás. Tese através de disposições contratuais, o risco envolvido no financiamento das instalações de geração e transmissão caro ao longo ao longo prazo foi reduzido. Estes arranjos institucionais estimularam o investimento nas atividades da cadeia do gás natural, já que os investimentos realizados eram recuperados.

Desta forma, a receita dos produtores de gás natural dependia dos preços dos derivados de petróleo para os diferentes tipos de consumo final. Os transportadores e distribuidores, por sua vez, sendo detentores dos direitos de monopólio, eram remunerados com uma taxa específica, que tinha relação com os custos de construção e operação dos dutos.

Até os dias atuais mercado de gás natural na Europa continental ainda é considerado pouco flexível, uma vez que grandes partes das transações ainda se encontram formalizadas por meio de contratos, cujos preços são atrelados ao preço do petróleo Durante os últimos 40 anos, a indústria europeia do gás obtia a segurança da demanda, por meio de agrupamento de contratos de fornecimento de longo prazo com base disposições take-or-pay, proporcionando flexibilidade limitada, e indexação de preços a garantir a competitividade no mercado (IEA, 2011). 


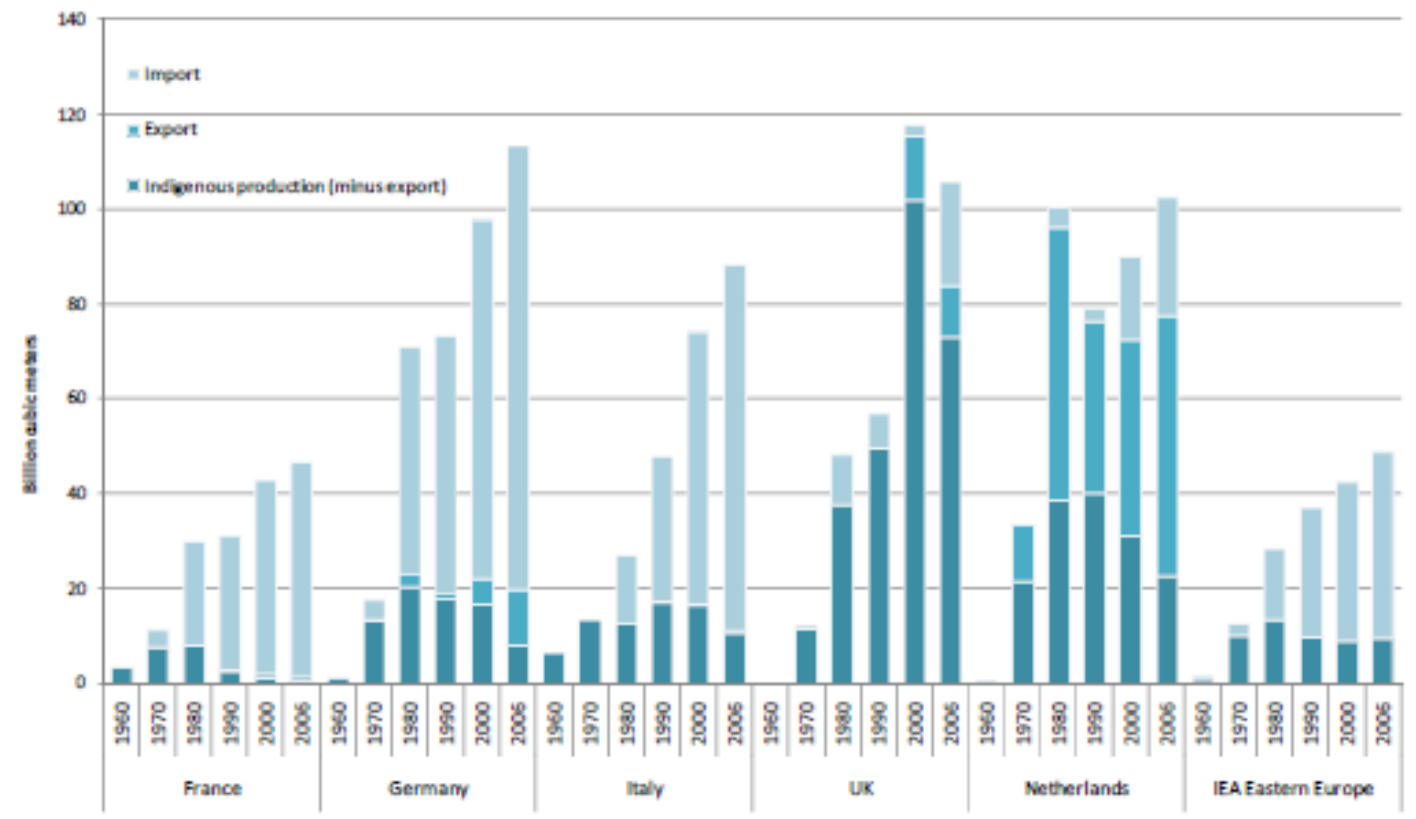

Figura 9 - Overview da dependência de importação no mercado europeu Fonte: IEA (2011)

Vale destacar, que o mercado europeu de gás natural ainda possui uma forte dependência das importações da Rússia. Wagbara (2007) destaca que $40 \%$ das importações de gás natural da União Europeia vêm de países como a Rússia, o Uzbequistão, o Turcomenistão e o Cazaquistão. 


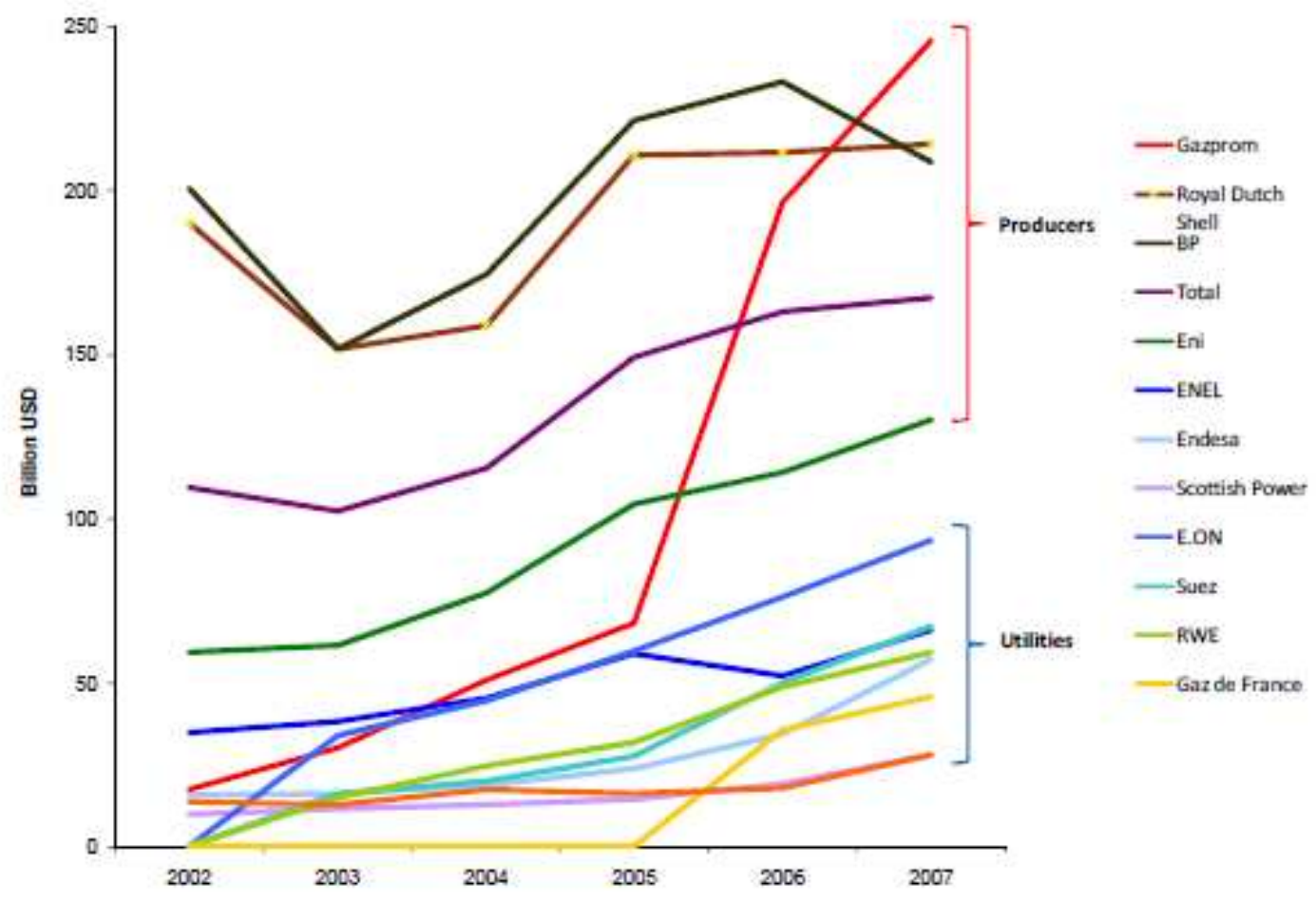

Figura 10 - Valor de mercado das maiores companhias europeias de gás natural Fonte: IEA (2012)

\subsection{Mercado de Gás Natural no Reino Unido}

Uma vez que o Reino Unido foi geograficamente isolado da rede europeia de gás continental, este mercado desenvolveu o seu próprio caminho, mais parecido com o mercado de gás dos EUA do que a Europa Continental. Assim, como no caso dos Estados Unidos e do Canadá, a malha de transporte de gás britânica inicialmente foi utilizada para transportar o gás manufaturado do carvão (IEA, 2002).

Em 1964, o governo britânico editou o Continental Shelf Act, pelo qual determinou que todos os direitos do setor britânico do Mar do Norte. Em 1958 na International Convention of the High Seas, em Genebra, foram estabelecidos os direitos das nações sob os recursos naturais em leito marítimo, bem como as fronteiras marítimas entre os países com relação ao Mar do Norte (PEEBLES, 1980). 


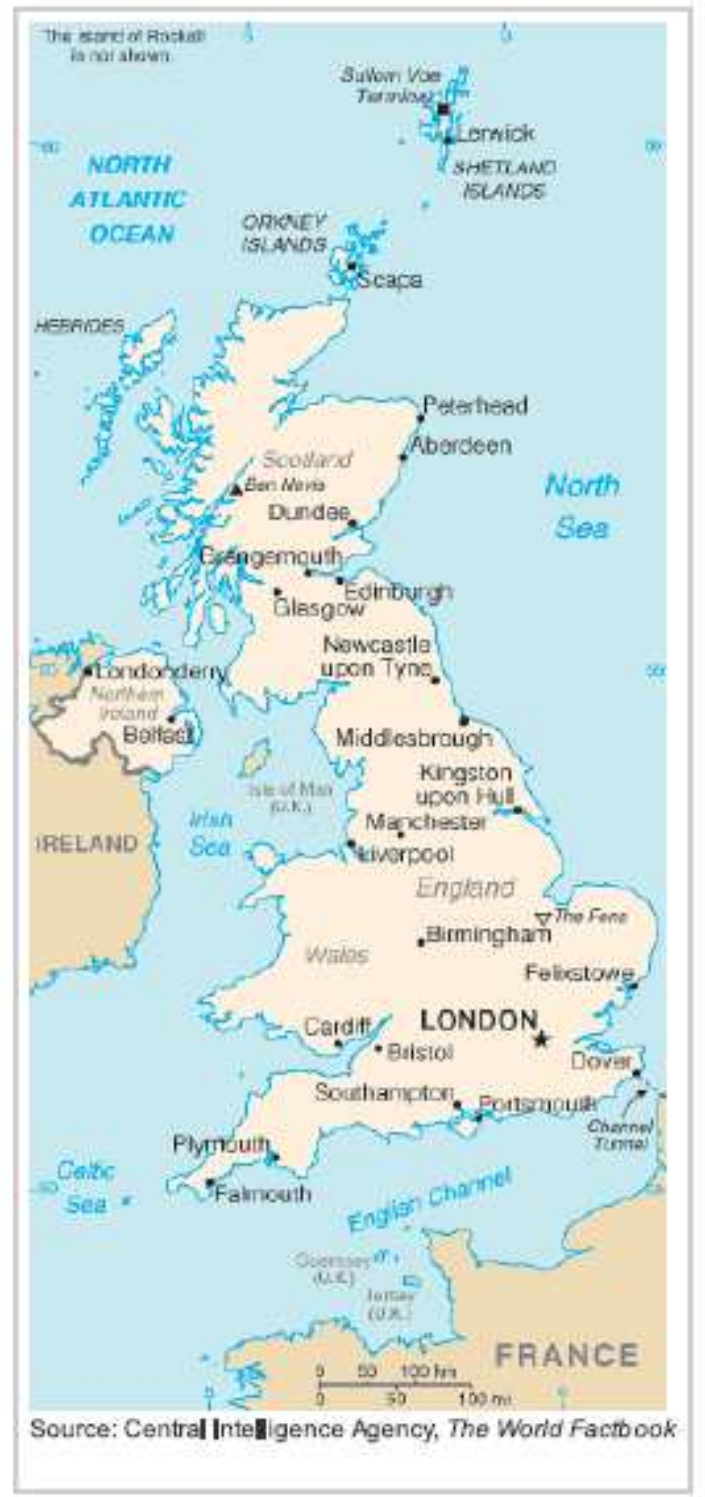

Figura 11 - Mercado de gás natural em UK

Fonte: Central Inteligence Agency (2010)

Originalmente, o gás utilizado no Reino Unido foi o gás sintético a partir do carvão, Este mercado foi principalmente dirigido por conselhos municipais e pequenas empresas privadas. Após a Segunda Guerra Mundial, Lei do Gás de 1948 foi alterada nacionalizando a indústria de gás do Reino Unido. Quando entraram em vigor em maio de 1949, mais de 1.000 companhias de gás de propriedade privada e municipais foram divididas em 12 áreas pelos conselhos de gás, geograficamente organizada e conhecida como British Gás (IEA, 2006). 
Foi no ano de 1972 que o Gás Act determinou a criação da British Gás (BG), uma empresa estatal, fundamental para o desenvolvimento do mercado de gás natural no Reino Unido, a empresa recebeu a incumbência de desenvolver e manter um sistema de suprimento de gás natural eficiente, coordenado para a Grã-Bretanha. Na realidade a BG foi criada para coordenar o sistema gasífero em âmbito nacional, otimizando as operações e evitando a competição pelo suprimento em diferentes regiões (PEEBLES, 1980).

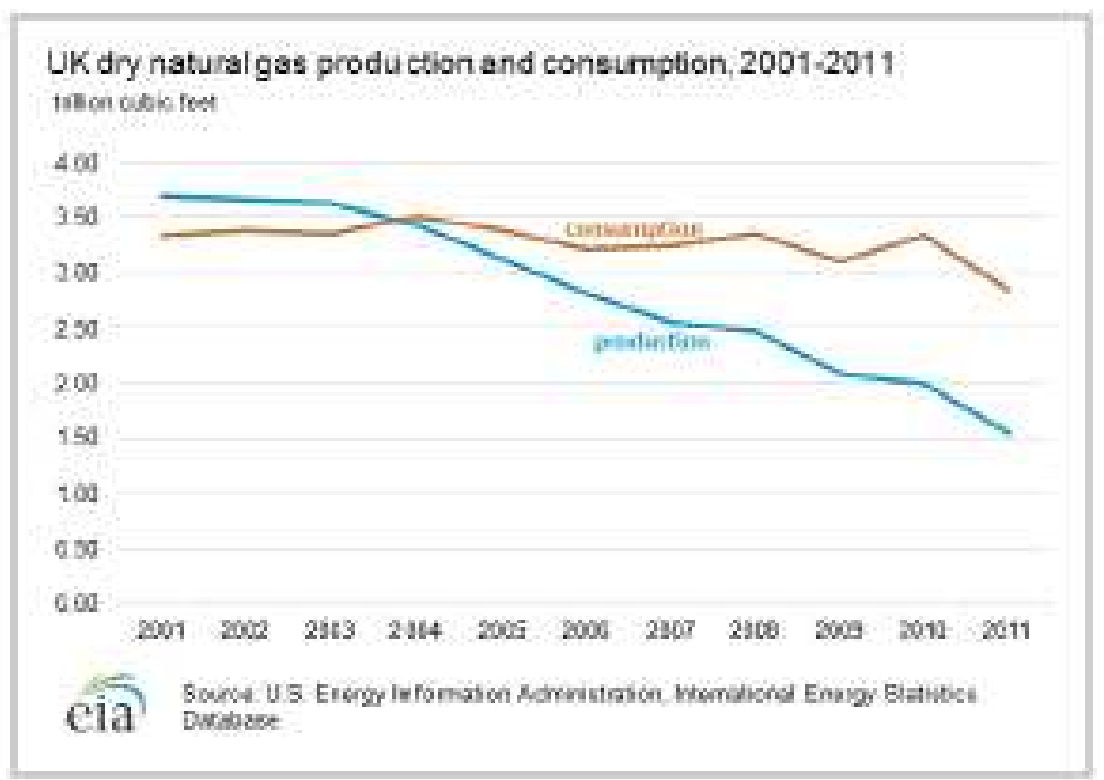

Figura 12 - Mercado de gás natural em UK produção e consumo Fonte: IEA (2012)

O próximo marco importante na história do Reino Unido sobre indústria de ocorreu em meados dos anos 1980. Os primeiros anos do governo liderado por Margaret Thatcher, que se iniciou em 1979, foram marcados por uma tentativa de usar o que alavancas estavam disponíveis para alocação de recursos e eficiência e preço.

Sob Thatcher, as políticas do governo fundamentalmente mudou o curso da evolução da indústria de gás do Reino Unido, que foi impulsionado principalmente pela percepção da necessidade de concorrência mais eficiente orientada para o mercado. Em 1982 foi promulgado o Oil And Gás Enterprises Act, o qual estabeleceu a intenção de privatizar a BG. Esta norma objetivava a quebra do monopólio da BG por meio da introdução da competição na oferta de gás natural para o mercado. 
O governo criou um órgão regulador do setor, o escritório de fornecimento de gás (Office of Gas Supply (Ofgas)) para proteger os interesses dos consumidores. Anos mais tarde se fundiu com Ofgas o regulador de energia elétrica a ser a estância de gás e mercados de electricidade. A política energética teve dois principais focos: criar um mercado para o comércio de commodities, e manter a infraestrutura necessária (o que seria monitorado pelo regulador de forma a garantir a igualdade de condições para as entidades privadas que operam no mercado) (KIM, 2004).

Tais como, haveria uma obrigatória separação entre o comércio de mercadorias e de transporte real. Em preparação para a abertura dos mercados de fornecimento de gás à concorrência em 1996, British Gas teve que passar por um grande processo de reestruturação, incluindo a redução de pessoal tem negócios substanciais. Tudo que separava a empresa em cinco novas divisões:

i. Fornecimento de gás Público para o mercado interno;

ii. Contrato de Negociação (mais tarde chamado de suprimento de negócios);

iii. Transporte e Armazenamento (mais tarde chamado Transco);

iv. Serviço e Instalação;

v. O IVA (mais tarde nomeado centros de energia).

Apesar das medidas, a concorrência no mercado de gás ainda enfrentara muitas barreiras de entrada. Diversas intervenções foram necessárias antes que o mercado tornasse totalmente liberalizado. Notavelmente, em 1988, os Monopoly \& Mergers Commission (MMC) emitiu um relatório sobre a British Gas que levava muitas recomendações que permitiria maior acesso para fornecedores de gás de terceiros na cadeia de valor do gás natural (SCHUTLEZ, 2011).

Em 1994, a British Gas foi novamente reorganizada. British Gas detinha os suprimentos offshore, armazenamento e todos os contratos de fornecimento incluindo aqueles adquiridos originalmente em um campo de esgotamento (com contratos de teses reunidas sob o mesmo grupo). O sistema de tubulação a jusante (Sistema Nacional de Transmissão - NTS) foi separada e independentemente operado. Este desenvolvimento 
auxiliado o processo de liberalização, que foi projetado para permitir que, de livre acesso transparente para o sistema de transmissão (CAGE, 2005).

Em 1998 todos os consumidores do país (incluindo 19 milhões de domicílios) tornaramse consumidores livres e a determinação dos preços ficou completamente aberta às forças do mercado. O mercado britânico de gás natural foi totalmente liberalizado, sendo um mercado autônomo dentro do continente europeu, como destaca IEA (2002)

De forma geral, o processo de liberalização envolveu a introdução de um novo quadro legal. Abrangeu "unbundling", ou seja, a separação entre propriedade e transporte da indústria, mudanças na propriedade de bens no British Gas, a introdução da concorrência da oferta, regulação e supervisão do sistema de transmissão e transporte em terra. O chanceler, Nigel Lawson, já havia Reconhecido cedo caindo nos anos Thatcher as questões estruturais relativas à combinação de redes de monopólio natural (FOSS, 2004).

O Reino Unido foi totalmente liberalizado, mercado competitivo e auto-suficiente de gás natural. Até o momento, o fornecimento de gás Reino Unido reagiu aos sinais de preços sentidoss pelo mercado. Com a abertura dos mercados à concorrência, o preço está se tornando um novo instrumento para equilibrar a oferta e a demanda. O livre acesso à infra-estrutura deu origem a mercados para o gás. Centros comerciais surgem onde geralmente vários oleodutos podem atender, Muitas vezes próximos ao local de armazenamento e áreas de alta demanda. No Reino Unido, a toda a rede nacional tornou-se um mercado único virtual para gás (KIM, 2004).

Assim como nos EUA, no Reino Unido o preço do gás natural é definido por meio do processo de competição. A Figura 13, abaixo, apresenta a infraestrutura de transporte do país. 


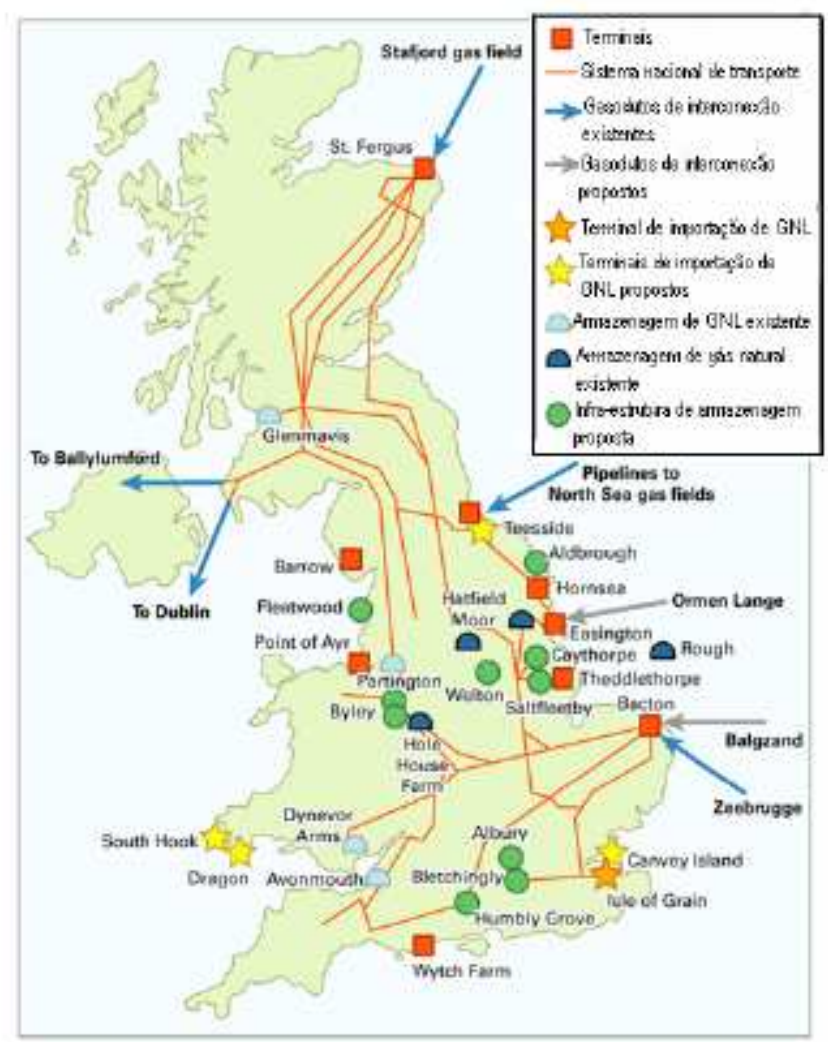

Figura 13 - Infraestrutura de transporte de gás natural no Reino Unido Fonte: JACKSON et al.(2006)

\subsection{Mercado de Gás Natural na Ásia}

Utilização de gás natural no mundo tem crescido ao longo das últimas duas décadas, refletindo os benefícios significativos de gás natural em uma era cada vez mais caracterizado pela preocupação com a segurança energética e aprofundamento restrições ambientais impostas pelas mudanças climáticas medos e crescente poluição. (CAGE, 2005).

A Ásia-Pacífico continua a ser o centro do gás mundial natural liquefeito (GNL) cerca de dois terços da demanda mundial de GNL. Japão e Coreia do Sul respondem por metade do mercado mundial de GNL, e aumento das importações de GNL para a China e Índia assegurar que a região Ásia-Pacífico continuará a ser a principal exigência centro de GNL (KIM, 2004). 
Dito isto, o gás continua a ser fonte de energia relativamente pouco utilizada na Ásia. Na realidade, a área ainda é fortemente dependente de petróleo e carvão para abastecer sua atividade econômica. Por exemplo, o Japão, a Coreia do Sul, Taiwan, Tailândia e ainda dependem do petróleo para cerca de $40 \%$ de suas necessidades energéticas, mesmo após duas décadas de esforços para reduzir a dependência do petróleo.

De acordo com dados da IEA (2012), a demanda por petróleo na China está crescendo a mais de 5\% ao ano. A China emergiu como o rapidamente tem segundo maior consumidor de petróleo e importador de seu parceiro mundial depois dos Estados Unidos. O gás natural apresenta uma oportunidade significativa para diversificar o consumo de energia industrial e de geração de energia da Ásia, além de reduzir a dependência das importações pesado da área do petróleo do Oriente Médio e da vulnerabilidade a potenciais choques do preço do petróleo.

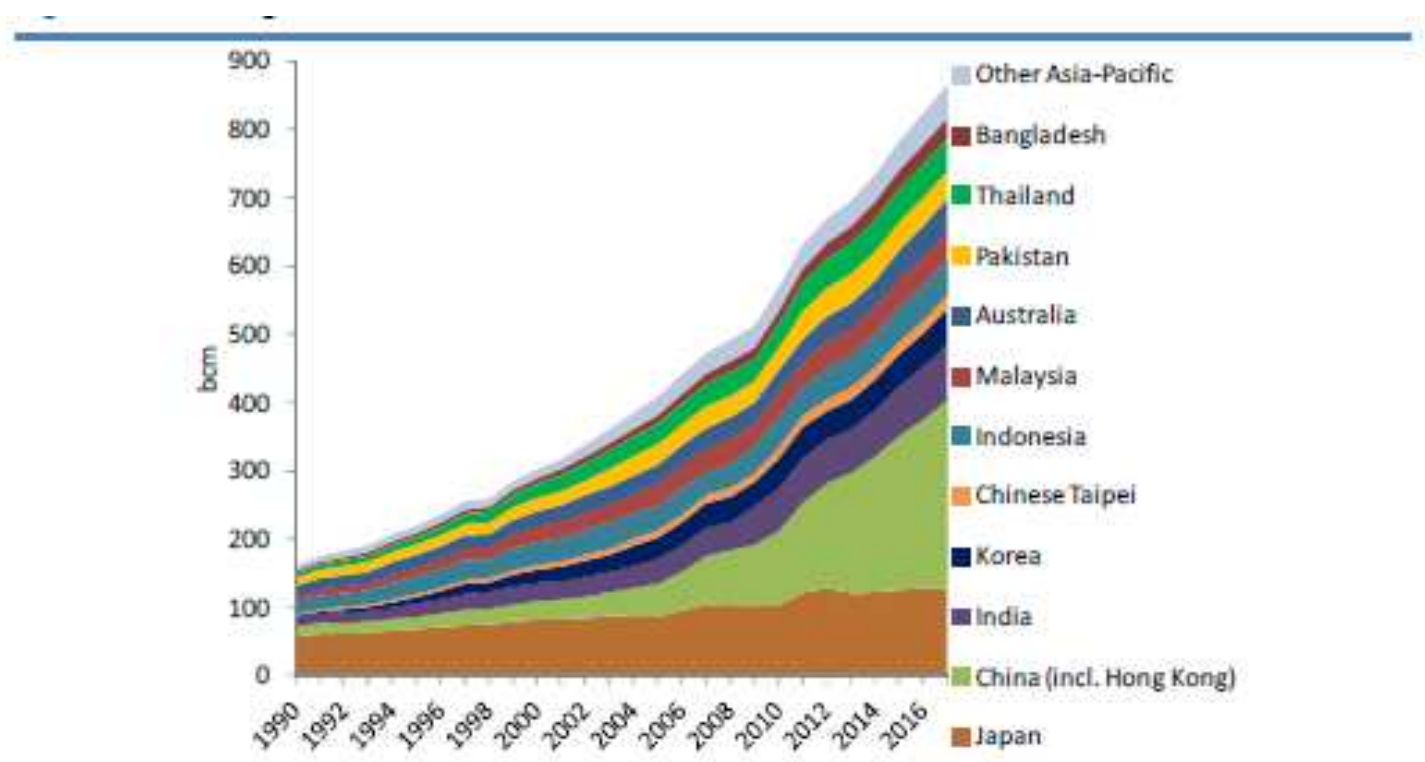

Figura 14 - Demanda por gás natural Ásia-Pacífico 1990-2016

Fonte: IEA (2012)

De acordo com relatório da Energy Pacific (2012), o carvão é responsável por mais de $50 \%$ do consumo de energia da Ásia Em comparação com a média global de apenas 16\% (excluindo a Ásia). Dessa forma, uso crescente de petróleo e de carvão na Ásia, os dois combustíveis intensivos em carbono explica porque emissões de carbono da Ásia estão a subir muito mais rápido do que a demanda global de energia da região. Como alternativa, o gás natural praticamente não produz emissões de enxofre, muito mais 
baixos níveis de óxidos nitrosos, 25\% -30 \% menos CO2 do que o petróleo, e 40\% -45 \% menos $\mathrm{CO} 2$ do que o carvão. Por isso, há enormes benefícios ambientais potencialmente expansão do uso do gás natural.

A região Ásia-Pacífico responde por 37\% da demanda global de energia total, enquanto representa apenas 17\% do mercado de gás global. Em comparação, a área é responsável por $66 \%$ da demanda global de carvão, $31 \%$ da demanda de petróleo e $25 \%$ do consumo nuclear e hidrelétrica global. Em dois grandes mercados maiores de energia da região, China e Índia, as contas de gás para um reles $4 \%$ e $10 \%$ do uso de energia, respectivamente. Mesmo a partir de 30 anos de desenvolvimento de GNL, nos próximos dois maiores mercados de energia grandes, Japão e Coreia do Sul, o gás representa apenas $17 \%$ e $13 \%$ do uso de energia, respectivamente (Energy Pacific, 2012).

Com um rápido crescimento ao longo das últimas duas décadas, ainda há enorme margem para aumentos na utilização de gás da Ásia Isso daria maior segurança energética e os benefícios ambientais. Do ponto de vista da segurança energética, da Ásia-Pacífico é relativamente mais autossuficiente em gás que em petróleo, com grandes reservas de gás e capacidade de produção no Sudeste da Ásia, Austrália e crescentes reservas de gás doméstico nas maiores economias de China e Índia. Além disso, de gás e capacidade de produção de GNL são mais diversificadas e globalmente localizados principalmente em países não-OPEP (CAGE, 2005).

Além disso, o desenvolvimento e transporte de GNL e gás através de gasodutos de longa distância requer uma forte cooperação e acordos entre governos, em relações de mercado de longo prazo e geopolíticas que para reduzir o potencial de confronto político. Finalmente, o gás é uma fonte de energia muito mais eficiente; Tem uma taxa de conversão de energia muito maior do que o carvão, especialmente nos de ciclo combinado de turbina a gás a tecnologia de geração de energia, tudo o que é até $50 \%$ mais eficiente do que o carvão convencional ou geração movidas a óleo (Energy Pacific, 2012).

Embora o uso de gás da Ásia esteja crescendo e existe um crescente reconhecimento da segurança energética e valor ambiental, sugere que o gás vai se tornar um grande combustível nos principais mercados da China, Índia, Japão e Coréia.Talvez mais 
importante fator para esta expansão, do uso do gás na Ásia tem-se seja grande dispersão geográfica da área e marítimo que fazem a "tirania da distância" um fator chave para o uso do gás asiático. Infraestrutura de transporte de gás natural absorve uma parte significativa do valor do recurso matéria, comparado com o petróleo, e as longas distâncias da Ásia ampliar essa restrição de custos. Recursos de gás, principalmente asiáticos estão no Sudeste da Ásia. Considerando que os mercados regionais tradicionais foram desenvolvidos no nordeste da Ásia, distância marítimo tornando uma questão crítica (KIM, 2004).

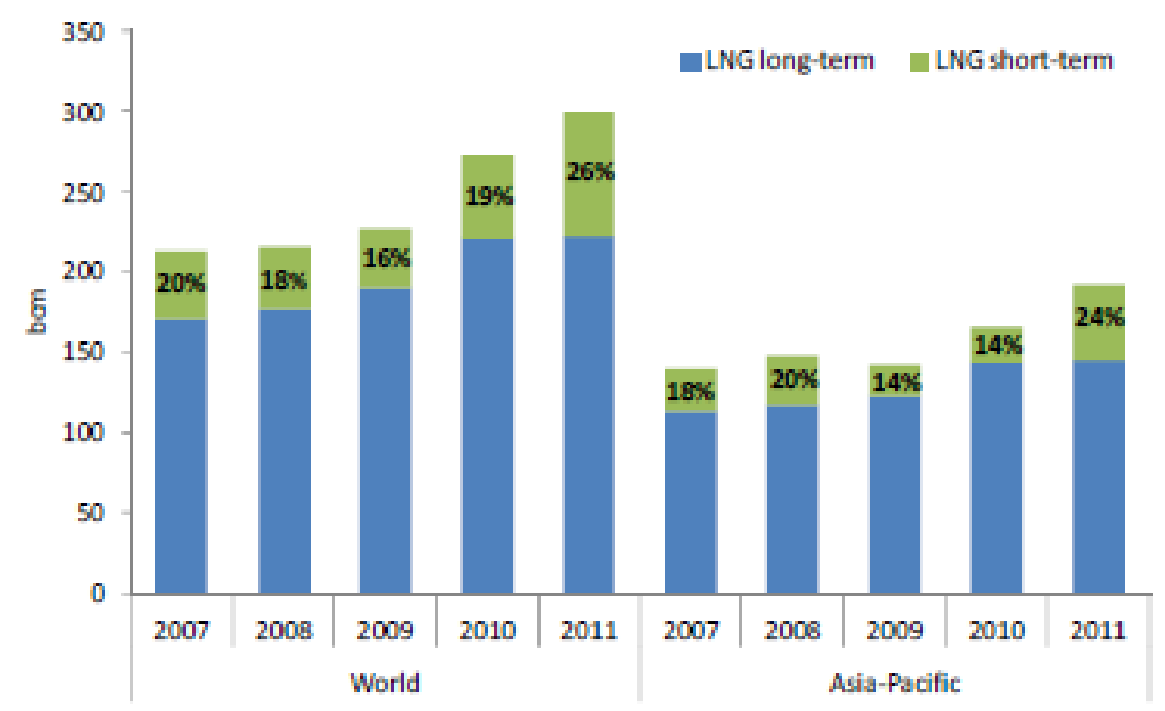

Figura 15 - Contratos de curto e longo prazo de GNL Asia-Pacifico

Fonte: GIIGNL (2012)

Como resultado, a opção de GNL, relativamente cara, tornou-se regionalmente negociadas fonte de gás, o gás e o desenvolvimento gasoduto tem sido muito mais limitado na Ásia do que nos mercados mais concentrados continentais da América do Norte e Europa. Intimamente ligado a este foi o desenvolvimento de fontes de GNL em grande parte impulsionado por preocupações de segurança energética no Japão e Nordeste da Ásia, produziu todos os que o sistema de preços indexados ao petróleo, como refletido na JCC (Japão cocktail bruto) fórmula de precificação que produziu relativamente de alto preço LNG (CAGE, 2005).

Enquanto as economias ricas do Japão, Coréia do Sul e Taiwan eram ble e dispostos a pagar preços mais altos, os altos preços têm - beens tese tem forte desincentivo para 
Países asiáticos em desenvolvimento que procuram expandir seu gás uso de contar com LNG (IEA, 2008).

No entanto, as perspectivas para o abastecimento de GNL estão crescendo com o desenvolvimento de um grande número de novos projetos dentro e fora da área. Exportações de fornecedores tradicionais Indonésia, Malásia, Brunei tem se estabilizado, as principais fontes novas tem vindo do noroeste área offshore da Austrália, bem como de futuras novas emenda de carvão projetos de GNL do gás na área de Queensland (GIIGNL, 2012).

Grande, novos suprimentos - regionais têm surgido em Sakhalin. O grande projeto da Rússia, e outros suprimentos offshore estão vindos de novos fornecedores: como Papua Nova Guiné (PNG) e Timor Leste. Além disso, fora dessa área, suprimentos de GNL do Oriente Médio têm sido impulsionados por grandes aumentos de produção de Catar e outros projetos de GNL regionais.

A percepção crescente de amplas fontes futuras de GNL tem sido alimentada pelo boom de gás de xisto nos Estados Unidos. Até recentemente, a maioria é previsões para o balanço global de GNL esperados nos Estados Unidos para se tornar uma importação maior de GNL como o fornecimento de gás da América do Norte e LNG diminuído gradualmente cada vez mais preenchido a lacuna. No entanto, mudou radicalmente as perspectivas para a produção de gás de xisto nos EUA sugere que a América do Norte não vai precisar de suprimentos de GNL, Tudo que mudou radicalmente a visão do equilíbrio geral (CAGE, 2005).

Além disso, o boom de gás de xisto pode se estender para a China e outros países da Ásia-Pacífico: como a Austrália, de acordo com análises geológicastêm fortes perspectivas de produção de gás de xisto. Isso foi possível adicionar ao aumento da produção de outro gás: metano de carvão não convencional: como suprimentos, na China e na Austrália (GIIGNL, 2012).

Outros trabalhos sugerem as perspectivas de GNL e o abastecimento de gás não convencional forte para a Ásia-Pacífico é cada vez mais susceptíveis de contribuir para 
a evolução de uma dieta mais flexível e amigável demanda de GNL. Os contratos de longo prazo podem ajudar a financiar o enorme investimento necessário. No entanto, os contratos - já se tornaram mais flexíveis em questões tais como: ligações do preço do petróleo, a take-or-pay (IEA, 2011).

Além disso, a imagem forte de fornecimento de gás parece proporcionar uma maior confiança entre os formuladores de políticas de energia na Ásia em desenvolvimento de GNL que os preços no longo prazo irá se mantiver razoavelmente competitivo e acessível. Estas trocas sugerem que tanto desenvolvidos como em desenvolvimento da Ásia poderia ver cada vez mais como uma opção de GNL combustível base de carga para o Crescimento Econômico Em vez de um de alto custo marginal pico de combustível suplementar (CAGE, 2005).

Intimamente relacionado com os desafios de aumentar a fornecimentos de GNL na região Ásia-Pacífico são os desafios do desenvolvimento de novas fontes de gás encanado para a área que iria expandir o acesso ea confiança na estabilidade de insumos importados. Em termos de custo e de mercado, a "tirania da distância" tem sido um desafio significativo para a expansão de gasodutos importações, em contraste com a posição na América do Norte e na Europa, onde as distâncias são muito mais curtas (KIM, 2004).

Em segundo lugar, o grande potencial de mercados continentais da China e da Índia, só recentemente começaram a se concentrar na expansão utilização de gás. Esses países tem sido lentos para desenvolver políticas eficazes de demanda doméstica e disposições regulamentares que daria confiança aos potenciais exportadores de apoio projetos de dutos largos dedicados aos seus mercados. O desenvolvimento de novos gasodutos para a Ásia-Pacífico tem sido minado pelos desafios geopolíticos complexoss de projetos de gasodutos multinacionais.

Além disso, no Sudeste da Ásia, o alto custo de gasodutos submarinos. Japão e Coréia apresentam perfis muito diferentes sazonais. Japão utiliza grandes volumes de gás para gerar eletricidade objetivo não depende diretamente sobre ele para aquecimento, é 
menos sujeito a variações sazonais do que a Coréia. Ambos os países têm desenvolvido diversas ferramentas para garantir a flexibilidade e a segurança do abastecimento em seus sistemas de gás.

Japão posteriormente montado em uma combinação de vários meios de clustering: tais como sistemas de abastecimento e de distribuição modulares que limitam a dependência de qualquer instalação single, além de oportunidades para substituição de combustíveis e de partilha através do sistema de geração de eletricidade. Coréia posteriormente montada em comprar cargas de GNL local para cobrir sua demanda de pico de inverno (CAGE, 2005).

Apesar das limitações de teses, novos desenvolvimentos regional de gasodutos têm começaram a tomar forma como os mercados continentais da Ásia, enquanto outros projetos continuam a enfrentar desafios. Pequim tem patrocinado grandes novos gasodutos regionais de Turcomenistão, Cazaquistão e Mianmar como China constrói uma linha tronco de infraestrutura de gasodutos de oeste para leste doméstico amplo. Esta iniciativa é tem sido apoiada por reformas graduais na política energética e preço para promover o uso de gás. Pequim vê importações de dutos terrestres, como forma de equilibrar planos crescentes para a importação de GNL ao longo da costa leste (KIM, 2004).

No entanto, os benefícios de uma maior expansão dos fluxos de gasodutos na área, deependerá da resolução de restrições geopolíticas crônicas. Consideráveis esforços da Índia para desenvolver dutos de transporte regionais para o enorme potencial fontes disponíveis nas proximidades fracassaram devido a pressões concorrenciais e geopolíticas. O potencial projecto do gasoduto Irã- Paquistão- Índia continua bloqueado pela rivalidade da Índia com sanções e pressão sobre o Irã Paquistão, EUA e da ONU, e suas exigências de preço de exportação do Irã (IEA, 2006).

Gazprom eo Kremlin permanecem incertas sobre a grande Cometer New investimento necessário para construir a infraestrutura de exportação gasoduto na Sibéria Oriental e sobre tudo o que as fontes de abastecimento de campo para se dedicar à China e 
Nordeste da Ásia . As exportações de gás para a Coreia do Sul são limitadass pela localização da Coreia do Norte e do aprofundamento impasse nuclear entre os países.

No Sudeste Asiático, enquanto a visão completa da ASEAN em rede de gás do Sudeste Asiático continua a ser uma possibilidade distante, várias partes de uma grade potencial futuro continua a ser colocado em local onde a economia de investimento faz sentido. Como resultado, Mianmar tem - se movido a gás por gasoduto para a Tailândia por muitos anos, e gás da Indonésia é exportado para Cingapura (IEA, 2006).

A terceira chave para o futuro do gás como combustível principal no desenvolvimento da Ásia-Pacífico é enfrentar o desafio de competir com o carvão como combustível base. Isso é extremamente significativo nas principais economias dependentes de carvão da China e da Índia. Carvão tem reinado em países devido ao baixo custo domésticos reservas e grandes reservas disponíveis, todos os que permitiram carvão para fornecer enorme base de carga de combustível de geração de energia para atender à crescente demanda de energia elétrica (HAYES, 2004).

Como um conteúdo de resultados, cada país tem profundamente enraizado o legado de relativamente baixo consumo de gás natural, os custos de combustível de geração de energia de carvão alimentado e preços baixos de energia elétrica que historicamente tem prejudicado os esforços políticos para impulsionar o desenvolvimento de gás e penetração no mercado. Na China, por exemplo, o carvão representa $80 \%$ da geração de energia, o gás é um apenas responsável por 1\% do consumo. Mesmo relativamente de baixo custo do gás doméstico ele tem sido incapaz competir com o carvão na geração de energia e no aquecimento local e distrital.

Algumas dessas restrições, no entanto, poderiam estar melhorando. O impacto do aumento do uso do carvão, em termos de poluição do ar, consequências para a saúde, e as emissões de carbono está dirigindo tanto na China quanto na Índia têm concentrados eforços para aumentar o share no consumo de energia doméstica. Embora grande foco seja no crescimento em sectores das energias renováveis, o gás é cada vez mais visto como uma ferramenta para reduzir o aumento de emissão de carbono dos países. 
A produção de gás doméstico e disponibilidade estão crescendo muito fortemente em Pequim e Nova Deli, por exemplo, começou a oferecer incentivos ao investimento maior desenvolvimento de gás para ambas as companhias nacionais de petróleo (NOCs) e para os investidores estrangeiros. Ambos os estados estão buscando maneiras para impulsionar o uso do gás para geração de energia em locais seletivos, onde o abastecimento de gás é bastante caro em particular quando comparado com o fornecimento de carvão devido a altos custos de transporte (CAGE, 2005).

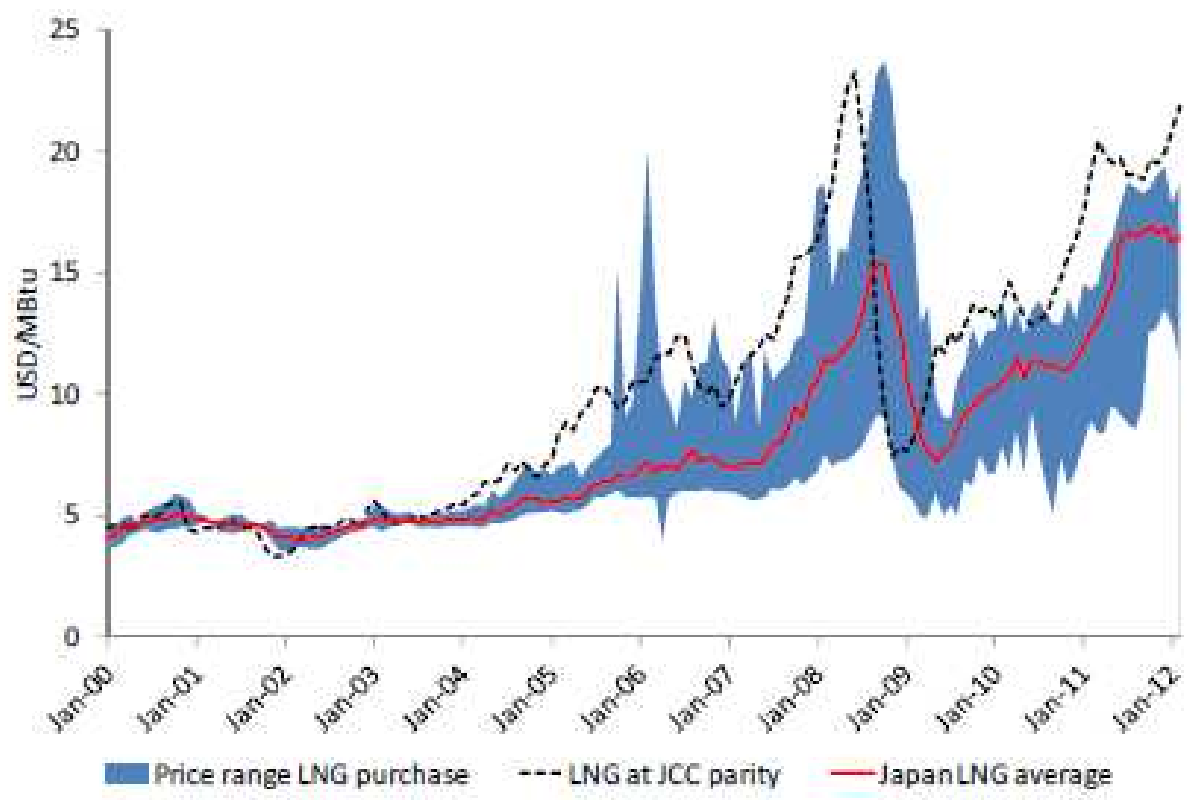

Figura 16 - Preço médio importação de GNL pelo Japão

Fonte: Japanese customs (2012)

Devido a políticas mais eficazes para aumentar a utilização de gás nos mercados residenciais e comerciais, o uso de gás em tese tem crescido recentemente Setores. Aponte a chave para fazer uma importante fonte de combustível - economia grande na China e na Índia será encontrar soluções políticas que aumentam a participação do gás na geração de energia. Isso exigirá grandes esforços por formuladores de políticas, já que o processo envolveria troca fundamental nos preços de energia elétrica (HAYES, 2004). 
Além disso, as indústrias do carvão de cada país são fundamentais para estabilidade social. Os formuladores de políticas em Pequim e Nova Deli precisa para se tornar confortável com as implicações da crescente importação de gás para a segurança energética, desde que os negócios substanciais de crescimento no uso do gás para geração de energia será colocada, principalmente, pelo fornecimento de gás importados tanto de GNL e de canalização.

\subsection{Mercado de Gás Natural na América do Sul}

O mercado da América do Sul não é representativo quando comparado aos quatro principais mercados gasíferos apresentados anteriormente. Ele possui, entretanto, um país com tradição no uso do energético - Argentina - e um importante mercado potencial para o gás natural - Brasil.

\subsubsection{O gasoduto Bolívia - Brasil (GASBOL)}

O gasoduto Bolivia-Brasil teve inicio de suas operações em 1999. Este gasoduto tem inicio na cidade de Santa Cruz de La Sierra, na Bolívia, atravessa os estados de Mato Grosso do Sul, São Paulo, Paraná, Santa Catarina e Rio Grande do Sul e termina na cidade gaúcha de Canoas. Possui cerca de 3.150 quilômetros de extensão, sendo 2.593 quilômetros em território brasileiro. O trecho brasileiro e administrado pela TBG Transportadora Brasileira Gasoduto Bolívia-Brasil S/A, subsidiaria da Petrobras, e o trecho boliviano pela GTB - Gás TransBoliviano S.A. Segue, na Figura 17, o traçado do Gasbol: 


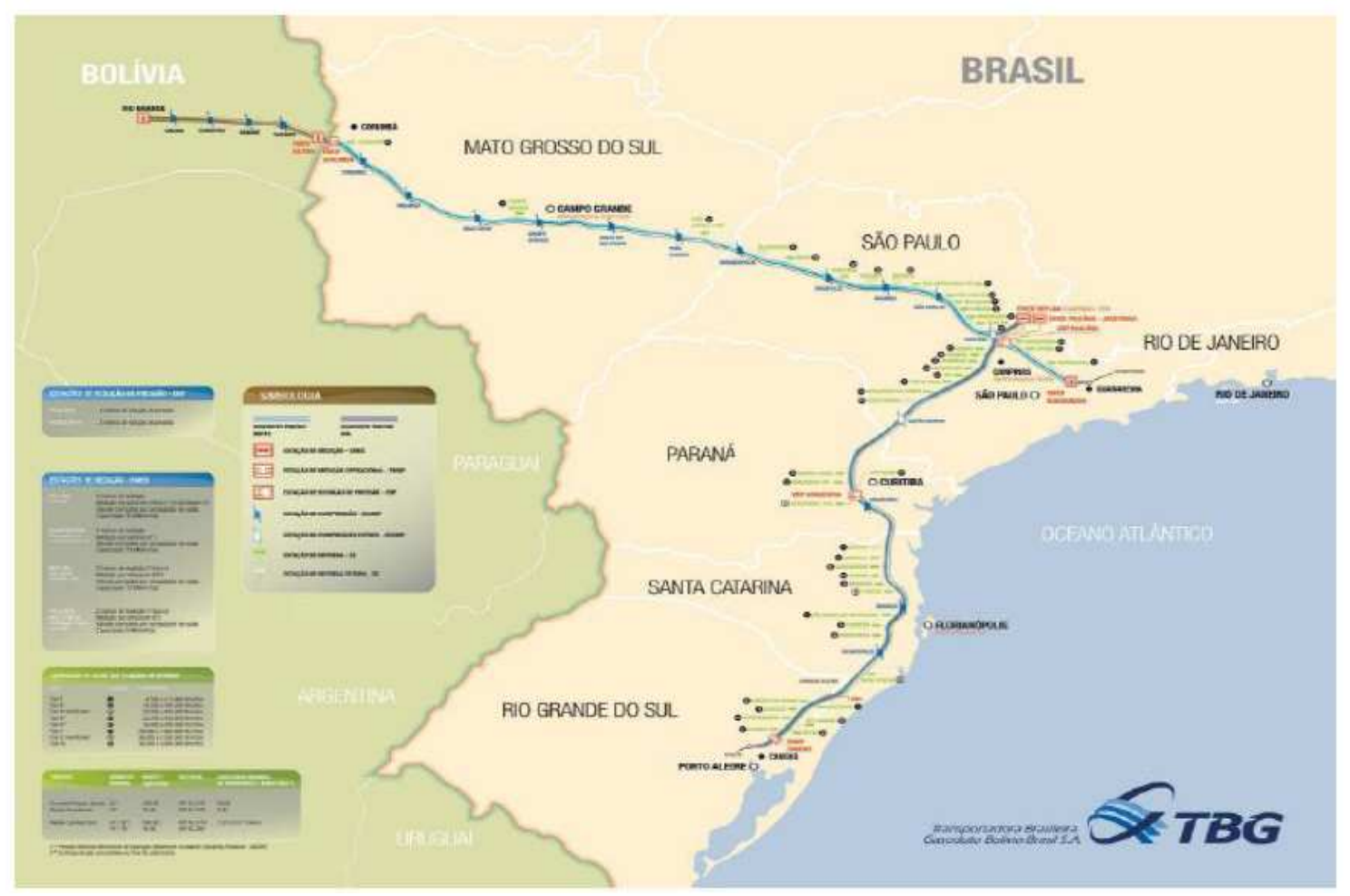

Figura 17 - Mapa do traçado do Gasoduto Brasil-Bolívia

Fonte: Transportadora Brasileira Gasoduto Bolívia-Brasil S/A. - TGB

Como mencionado anteriormente, o Gasbol possui uma capacidade de transporte de ate 30 milhões de metros cúbicos de gás natural por dia. Sua infraestrutura de dutos no Brasil - de 32 a 16 polegadas - e formada por dois trechos: o Trecho Norte, que liga Corumbá (MS) a Guararema (SP) e o Trecho Sul, que liga Paulínia (SP) a Canoas (RS).

Quanto ao inicio das atividades deste empreendimento, o Trecho Norte entrou em operação em agosto de 1999, sendo a entrega do gás natural feita, neste período, nos pontos de entrega de Paulínia e Guararema, ambos em São Paulo. Com a inauguração do Trecho Sul, em marco de 2000, o gasoduto entrou em operação plena, desde o Centro-Oeste ate o Sul do Brasil, iniciando o transporte de gás natural para os estados do Paraná, Santa Catarina e Rio Grande do Sul.

Além disto, no que diz respeito a operação e monitoramento dos dados operacionais do gasoduto, estes são feitos a distancia, através de satélite, pela Central de Supervisão e Controle da TBG, no Rio de Janeiro (Salomão, et. al, 2008). 
O avanço das negociações aconteceu com a garantia da Petrobras, da demanda de um mercado ainda por desenvolver para uma oferta de gás a ser descoberta em volume de reservas suficiente. Ao comprar o gás boliviano no regime take or pay por 20 anos, a Petrobras viabilizou os financiamentos para a construção do gasoduto, pois havia receita garantida por 20 anos para securitizar o empreendimento.

A Petrobras realizou uma compra adicional de gás e assumiu o custo da ampliação do gasoduto. Outro ponto importante, de caráter institucional, foi a disposição vigente na constituição brasileira que reserva às empresas estaduais o monopólio da distribuição do gás, sem considerar que as mesmas não tinham condições de arcar com compromissos de longo prazo do tipo take or pay. Isto foi contornado na medida em que a Petrobras se subrogou nesta condição de comprador firme e irretratável do gás boliviano, adequandose os contratos a tal circunstância (Salomão, et. al, 2008).

Fatores contrários à execução do projeto do Gasbol foram: (i) a concorrência exercida pela Argentina, que pretendia vender ao Brasil gás natural produzido em seus campos do norte do país; (ii) e às insistentes ofertas da Shell, então proprietária das reservas de gás de Camisea, que tentava vincular o mercado brasileiro àquele projeto para viabilizálo.

\subsubsection{O gasoduto Argentina - Brasil}

A partir de julho de 2000, a Argentina passou a vender gás ao Brasil, através do gasoduto que interliga sua rede doméstica TGN, a partir de Aldea Brasilera (centro-leste argentino), à cidade de Uruguaiana. O gasoduto abastece a termelétrica de Uruguaiana e poderia ser estendido até Porto Alegre, caso as expectativas argentinas quanto às suas reservas de gás natural se confirmassem. No momento atual com a crise de abastecimento de gás natural na Argentina, e as favoráveis condições hidrológicas no sul do Brasil, essa termelétrica está parada (Salomão, et. al, 2008).

\subsubsection{O gasoduto Bolívia - Argentina}

No final dos anos 60, a Argentina comprava cerca de 2 MMMCPD de gás da Bolívia, através de contrato de suprimento por 20 anos. Para tal, fora construído o gasoduto Yacimientos-Bolivian Gulf (YABOG), de $440 \mathrm{~km}$ de extensão e vazão máxima de 6 milhões de pés cúbicos por dia. 
Em meados dos anos 80, o preço do petróleo caiu e os custos decorrentes do contrato de compra do gás boliviano tornaram-se caros e inconvenientes para a Argentina, cuja produção de gás aumentara substancialmente. No início da década de 90, o preço do gás boliviano fornecido através do YABOG era praticamente o dobro do cobrado em novos fornecimentos de gás argentino.

O preço do contrato com a Bolívia foi renegociado e, na ocasião, a Argentina adiantou que não renovaria o contrato, tendo em vista a significativa ampliação de suas reservas, que lhe permitiria passar à condição de país também exportador de gás. A Bolívia ficaria em dificuldades, caso não houvesse a iniciativa do GASBOL com o Brasil.

De fato, a Argentina tornou-se exportadora de gás natural para o Chile, para o Uruguai e para o mercado meridional do Brasil. Menos de 10 anos depois, porém, com a explosão do consumo doméstico e a estagnação dos investimentos exploratórios no país, os argentinos constataram que as reservas provadas não são suficientes para suprir a demanda projetada no prazo de 20-30 anos. Isto os levou a intensificar a importação de gás natural da Bolívia através do YABOG, em 2004, e a negociar um novo contrato para aquisição de até 27,7 MMMCPD de gás boliviano através de um novo Gasoduto del Nordeste de la Argentina (GNEA) a ser construído ao custo estimado de US\$ 1,5 bilhões.

A situação do suprimento ao mercado doméstico argentino tornou-se crítica ao ponto de obrigar as autoridades energéticas do país a impor cortes freqüentes nos fornecimentos ao Chile e ao Uruguai, bem como a restringir o fornecimento de gás veicular (GNC).

\subsubsection{Os gasodutos Argentina - Chile}

A Argentina iniciou as exportações de gás natural para o Chile em 1996, permanecendo este, até hoje, como o maior mercado externo para o gás argentino. Sete gasodutos interligam os dois países: três deles ao sul, conectando a bacia produtora austral argentina à Punta Arenas no Chile. São denominados: Tierra del Fuego, também conhecido por Methanex-PA (entrou em operação em 1996); El Condor- Posesión, ou Methanex-YPF (entrou em operação em 1999) e Patagónico, ou Methanex-SIP (entrada em serviço também em 1999), que suprem plantas de produção de metanol no sul do Chile. Além desses : o Gas Andes liga La Mora, na província de Mendoza, a San 
Bernardo, nos arredores de Santiago. Inaugurado em 1997, abastece a capital chilena e uma termelétrica de 379 MW em Nueva Renca, Chile; o Gasoducto del Pacífico se estende dos campos produtores da província argentina de Neuquén à região de Bio-Bio, ao sul da zona central do Chile.

Sua operação comercial teve início em novembro de 1999. Fornece gás a diversas indústrias e consumidores comerciais e residenciais de Concepción, a segunda maior cidade chilena; em 1999, foi concluída a interconexão da rede gasífera argentina em Corneja, província de Salta, com a cidade de Mejillones, na costa norte do Chile, através do gasoduto Gas de Atacama. Supre usinas termelétricas e consumidores industriais no norte do Chile, a partir de jazimentos do noroeste argentino; e, finalmente, o gasoduto Nor Andino que acompanha o traçado do Gas de Atacama, ligando a bacia de Salta a Mejillones (Chile). Desde novembro de 1999, fornece gás natural na desértica região de Atacama a grandes consumidores industriais, incluindo a maior refinaria mundial de cobre, bem como a termelétrica de Tocopilla (Salomão, et. al, 2008).

\subsubsection{Os gasodutos Argentina Uruguai}

A Argentina exporta gás para o Uruguai pelo chamado Gasoducto Del Litoral, que iniciou sua operação em 1998, ligando Colón, na província argentina de Entre Rios, a Payssandú no Uruguai.

Existe ainda o gasoduto Cruz del Sur, que a partir de 2002, abastece o mercado uruguaio com gás natural da bacia de Neuquén, passando por Buenos Aires e chegando a Colonia e Montevideo do outro lado do Rio da Prata. Esta conexão é parte de um projeto de maior envergadura que interligaria a Argentina ao sul do Brasil, através do Uruguai, e que não se materializou. 


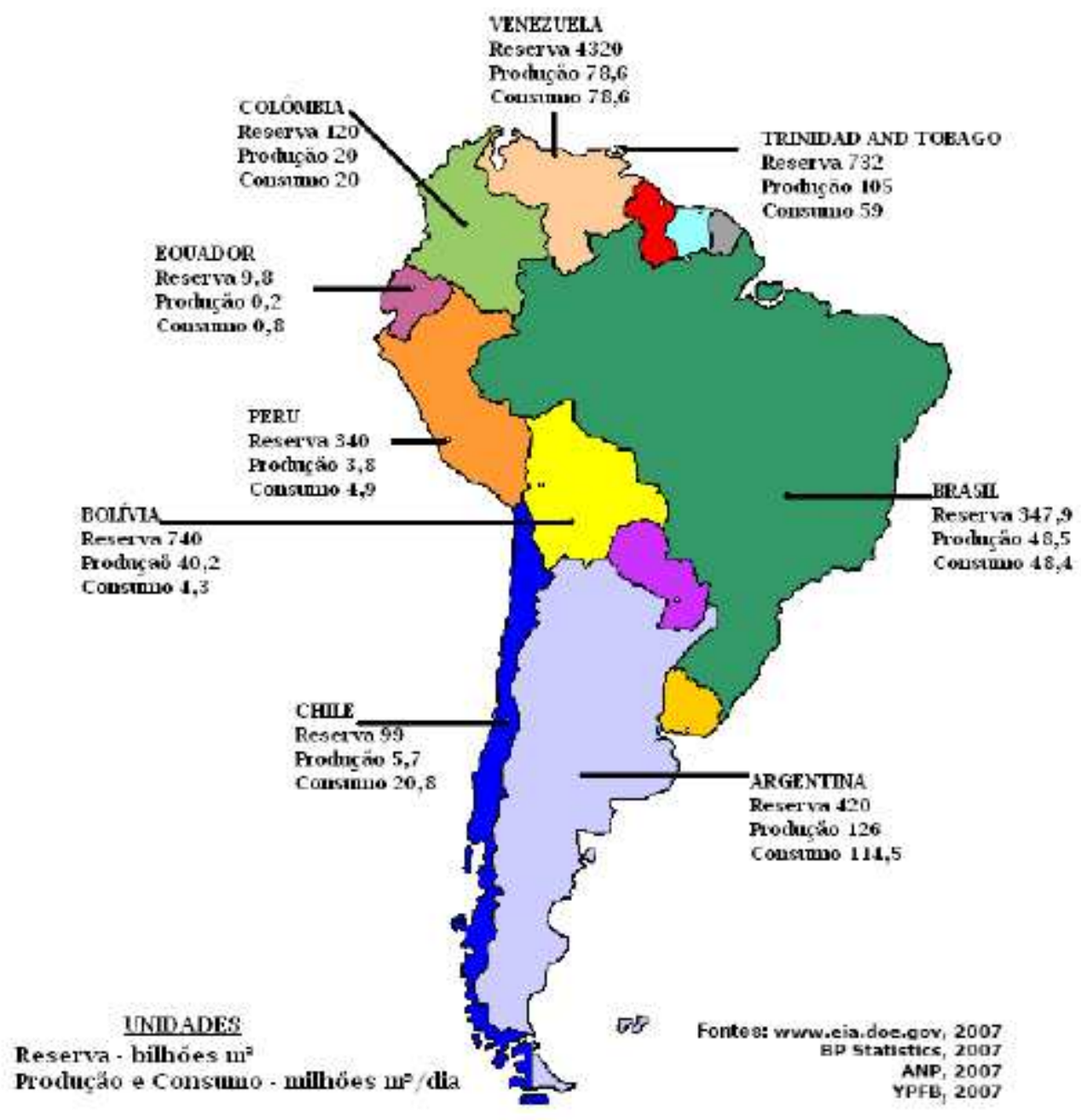

Figura 18 - Reserva, consumo e produção de gás natural na América do Sul Fonte: Petroleum Economist, 2009 


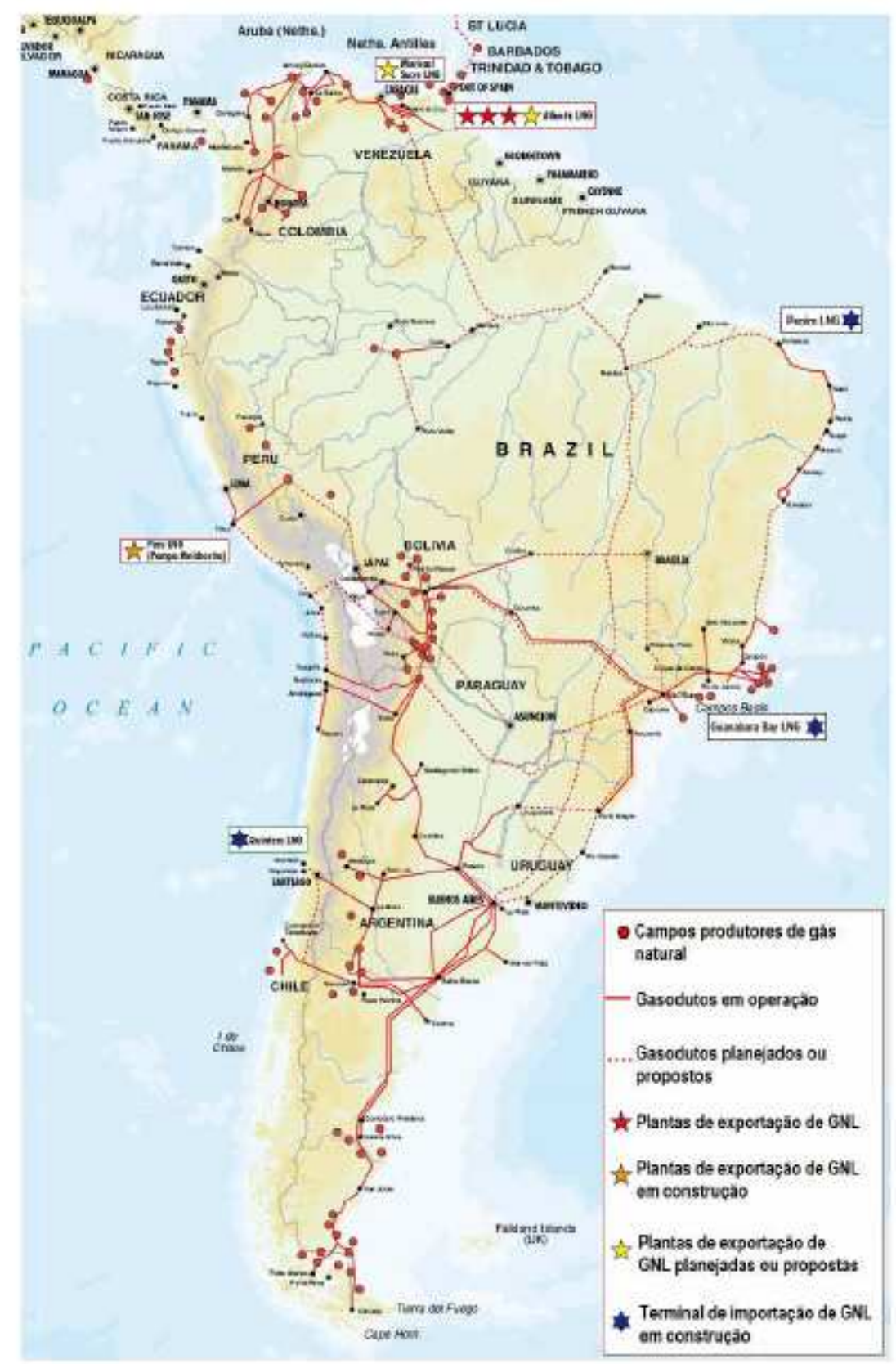

Figura 19 - Infraestrutura de produção e transporte de gás natural na América do Sul Fonte: (Petroleum Economist, 2007b)

\section{O GÁS NATURAL NO BRASIL}

A partir da situação anteriormente apresentada sobre alguns mercados internacionais, este capitulo contextualiza as atuais características e estágios de desenvolvimento das diversas pontas da cadeia industrial e do mercado brasileiros de gás natural. 


\subsection{Breve Histórico da Indústria do Gás Natural}

A indústria de gás natural no Brasil iniciou a passos tímidos a partir da década de 1940 com as descobertas de óleo e gás no Recôncavo baiano. No final da década seguinte (1950) a produção já chegava a 1 milhão de metros cúbicos de gás por dia, valor este que subiu para 3,3 milhões de metros cúbicos em 1960 e já atendia a uma refinaria e a todo o polo petroquímico de Camaçari.

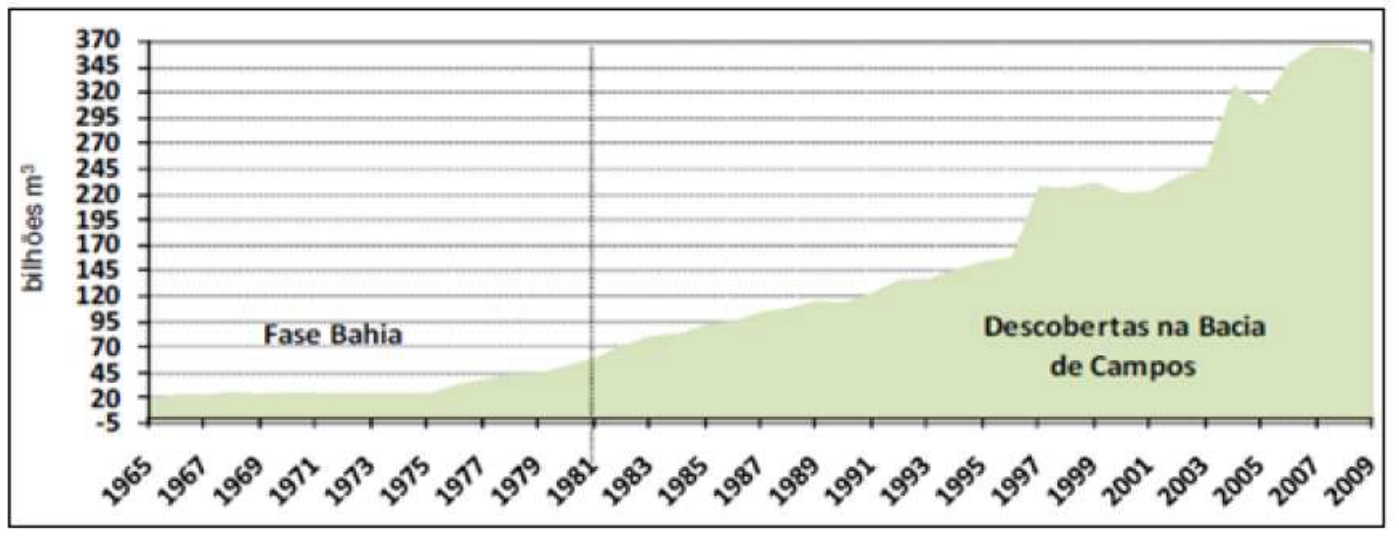

Figura 20 - Reservas provadas de gás natural no Brasil de 1965 a 2009

Fonte: Boletim Mensal do Gás Natural - Numero 14 - ANP / MME

No período de 1980 a 1995, as reservas provadas brasileiras praticamente triplicaram com a descoberta da Bacia de Campos, aumente ando sua participação na matriz energética brasileira para cerca de $3 \%$.

Na década de 1990, foi iniciada a construção do Gasoduto Brasil-Bolívia- Gasbol. Este empreendimento entrou em operação em 1999, com capacidade de transporte de 30 milhões de metros cúbicos de gás por dia, e se tornou um fator fundamental para a consolidação da indústria de gás natural no Brasil.

Em 2001, com a crise do setor elétrico, o governo federal passou a incentivar a construção de usinas termelétricas movidas a gás natural, através da criação do PPT (Programa Prioritário de Termelétricas, programa instituído em âmbito do Ministério das Minas e Energia através do Decreto número 3.371, de 24 de fevereiro de 2000), e a Petrobras, no papel de maior produtor de gás no pais, incentivou a criação de novos mercados para o consumo daquele combustível, através do Plano de Massificação do 
Uso do Gás Natural. Plano anunciado em 2003 pela Petrobras que tinha como principal característica o congelamento do preço do gás natural entre 2003 e a metade de 2005.

Observou-se entre os anos de 2002-2008 no Brasil um crescimento no consumo de gás natural a taxas medias de $18 \%$ aa, superando em muito, a taxa media de crescimento do Produto Interno Bruto do período, que girou em torno dos 3\%. Para incentivar o seu consumo, o governo federal criou incentivos, como garantia de fornecimento aos novos consumidores, o que em pouco tempo tornou-se uma meta difícil de ser concretizada dada a demanda crescente das usinas termelétricas nos anos que se seguiram.

Neste cenário, a oferta de gás natural no país passou a não ser suficiente para atender simultaneamente as demandas da indústria e das usinas termoelétricas do país movidas a gás natural. O Brasil passou rapidamente de uma situação de excesso de oferta de gás natural para outra de sub-oferta.

\subsection{A Participação do Gás Natural como Energia Primária no Brasil}

O aumento das reservas e da produção de petróleo permitiu viabilizar o contínuo crescimento da participação do gás na matriz energética desde o início dos anos 1990. Não tendo nenhuma tradição na utilização do gás natural e com pouquíssimas cidades dispondo de redes de distribuição de gás manufaturado, a penetração do gás natural na matriz energética brasileira se fez lentamente e apoiada no consumo de grandes clientes. Note-se de imediato que, considerando a experiência internacional mencionada na seção anterior, esta trajetória é oposta àquela percorrida pelos primeiros países consumidores, que sustentaram o crescimento inicial apoiados na demanda residencial e pública como Estados Unidos, Alemanha e Japão. 


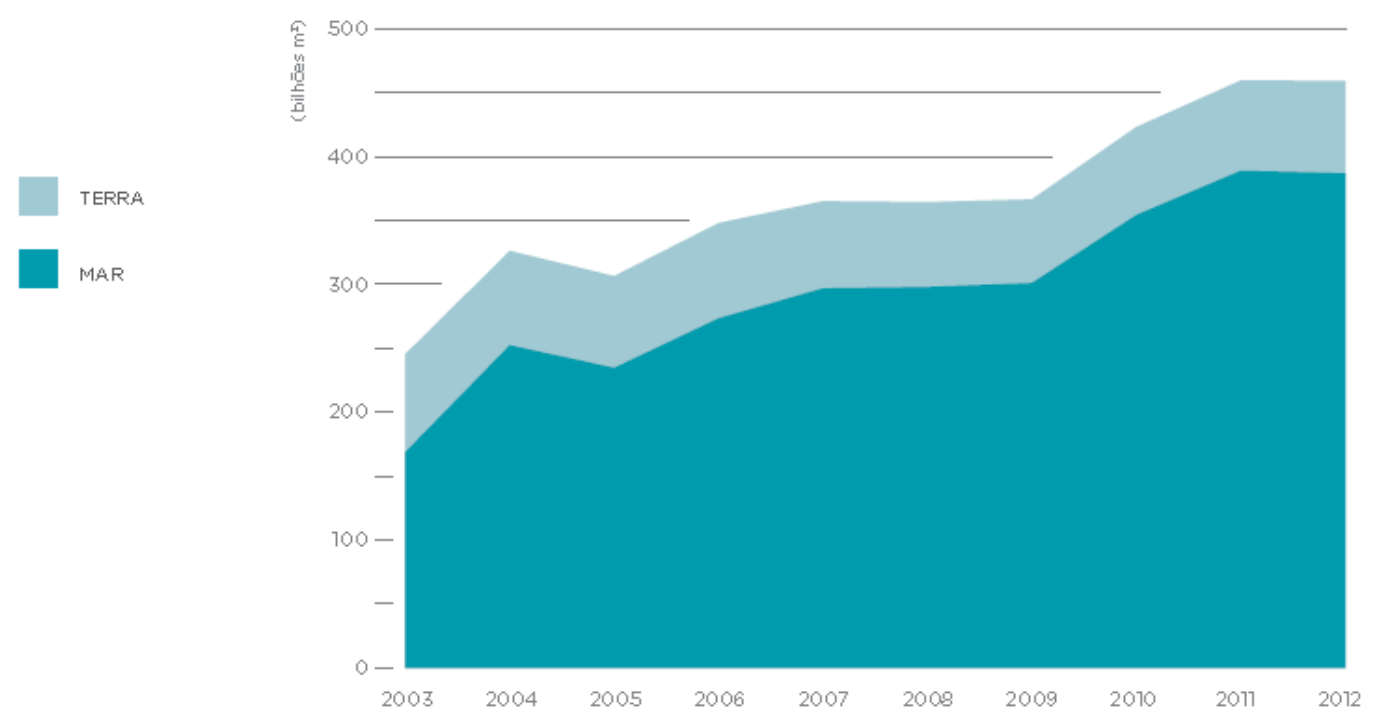

Figura 21 - Evolução das reservas brasileiras provadas de gás natural Fonte: ANP (2012)

Como observa Checchi (2001), no Brasil a utilização do gás natural, em grande escala, só ocorreu a partir do início da década de 1960Em razão do crescente volume de gás natural associado ao petróleo descoberto na Bahia e em acordo com a política de substituição das importações de derivados, em 1962, a Petrobras instalou a primeira unidade de processamento de gás natural (UPGN) do país, no Município de Pojuca. Em 1964, a unidade estava em pleno funcionamento, extraindo condensados (butano e propano para produção de gás liquefeito do petróleo) e gasolina natural, $132 \mathrm{mil} \mathrm{m}^{3}$ naquele ano. Durante toda a década de 1960, este foi o único empreendimento a aproveitar o gás natural no país (Checchi et al.,2001).

A década de 1970 no Brasil foi marcada pelos dois choques do petróleo eas elevadas taxas de crescimento econômico, culminando no o desequilíbrio na Balança Comercial. Entretanto, também foi uma década marcada por descoberta de ocorrências de gás natural em vários estados nordestinos, no Espírito Santo e no Rio de Janeiro, marcaram a. Com bastante retardo comparado a outras fontes que, ao longo da segunda metade daquela década, foram objeto de programas especiais (petróleo, álcool, xisto e nuclear), o aproveitamento em escala nacional do gás natural só foi iniciado, de fato, a partir de 1980 (ANP, 2001). 
O setor industrial, desde o início, foi o maior responsável pela demanda desse combustível. De acordo com dados da ABEGÁS (2012) em 1997 a fatia de consumo do segmento industrial representava cerca de $88 \%$ do consumo nacional de gás natural. Entretanto, com a expansão do uso em todos os outros segmentos de consumo como de geração elétrica, comercial, residencial e automotivo, essa participação na parcela de consumo vem caindo gradativamente ao longo dos últimos anos e dados atuais mostram que o consumo industrial corresponde por cerca de $50 \%$ da demanda brasileira..

Na década de 1990, a utilização do gás como insumo energético para produção industrial tornou-se o maior segmento de consumo, superando a produção de combustíveis e as utilizações não energéticas. Os novos clientes foram majoritariamente setores intensivos em energia: indústrias do vidro e da cerâmica, papel e celulose, alimentos e bebidas, cimento e metais não ferrosos, mineração e pelotização (Petrobras, 2006).

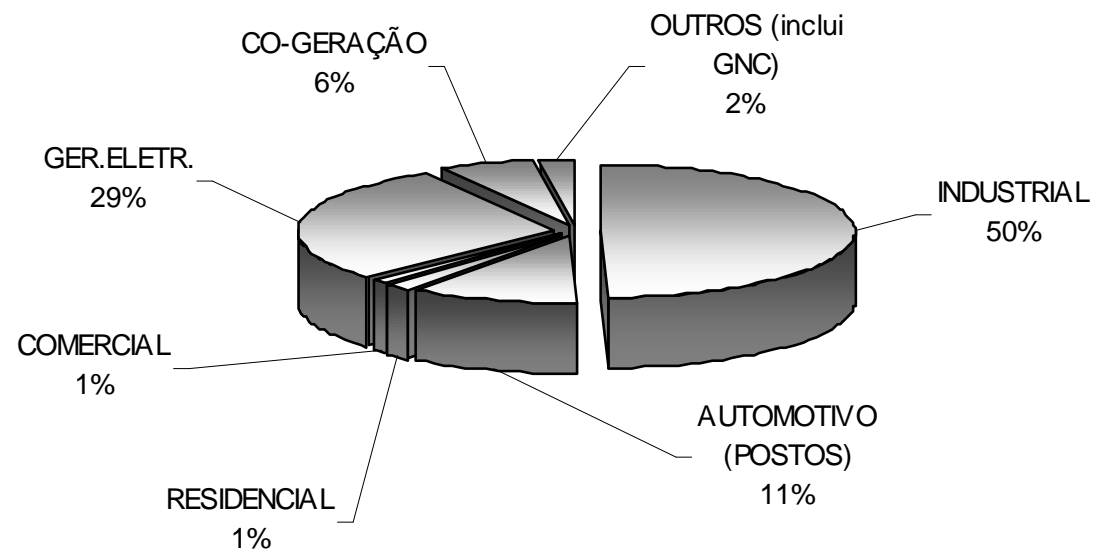

Figura 22 - Consumo de gás natural no Brasil - Por setor Fonte:ABEGÁS (2012)

O início do aproveitamento do gás natural no Brasil reflete com bastante nitidez os condicionantes técnicos de sua utilização, conforme citado nas seções anteriores. Seu potencial de consumo é extremamente elevado desde que, (i) existam jazidas próximas aos consumidores, (ii), demonstre ser pelo menos tão eficiente quanto o petróleo na produção de hidro carburantes ou petroquímicos (ANP, 2001). 
Soares et al. (2000) avaliam que em todos os setores, o peso da energia é decisivo para os custos finais e a seleção correta pode significar a viabilidade ou não do projeto. Os fornos, fornalhas, estufas, caldeiras, secadores, autoclaves, calandras e maçaricos são equipamentos que, nestas indústrias, podem ser abastecidos por eletricidade, óleo combustível, carvão e também gás natural. Este último, por ser limpo, não entope os dutos e injetores, além de poder ser queimado diretamente, obtendo-se uma combustão completa. Nas indústrias de vidro, cerâmica, alimentos e bebidas, estes fatores são determinantes na seleção da fonte de energia, uma vez que a qualidade final do produto é diretamente afetada.

Schwob (2007) aponta que na medida em que está acessível em pressões e volumes elevados e a preços competitivos, para os grandes consumidores em qualquer segmento produtivo, o gás natural apresenta algumas vantagens indiscutíveis: menores imobilizações em equipamentos e custos operacionais, maior rendimento energético, relativamente fácil acesso a grandes potências, inexistência de armazenagem e reduzida emissão de poluentes.

Com todos esses atrativos, a partir do momento em que esteve disponível nos grandes centros industriais do país, o gás natural alcançou clientes nos mais diversos setores de atividades. A retomada da economia após 1992 e a volta do investimento estrangeiro, após o ajuste monetário de 1994, contribuíram de maneira significativa para esta diversificação.

Finalmente, encontram justificativa e financiamento os projetos de instalação de novas plantas industriais; mais importante quanto à questão energética, a partir de então, o fornecimento de gás natural passa a ser considerado uma alternativa para os projetos. Viabilizados pela implantação das UPGNs (Unidades Processadoras de Gás Natural Nacionais), durante a década anterior, e pela rápida expansão da malha de gasodutos, também no mesmo período, este contínuo crescimento da procura e sua progressiva diversificação demonstram que o gás natural passa a dispor de vantagens suficientes para justificar sua penetração em todo tecido industrial (ANP, 2001).

Ao longo dos anos a eletricidade ganhou muita importância para o setor industrial. Em 2009 representava 20,9\% da demanda de energia da indústria, sendo logo seguida pelo 
bagaço da cana 19,3\% e em terceiro colocado o gás natural que é responsável por 9,3\% da demanda energética do segmento industrial. A Tabela 1, a seguir, apresenta a evolução, a partir de 2003, do consumo de energia do segmento industrial.

Cecchi (2001) afirma que tudo indica que o gás natural conseguiu capturar não somente os novos projetos, mas também as ampliações e, por fim, a partir da conversão, conquistou consumidores tradicionalmente abastecidos por outros combustíveis. $\mathrm{O}$ principal atingido foi o óleo combustível. O exemplo da Cosipa é ilustrativo: entre 1993 e 1998, foram substituídas 100 mil toneladas de óleo, de forma que a participação deste no consumo energético da empresa cai de $6 \%$ para $1,1 \%$, enquanto a participação do gás natural salta de zero para $7,6 \%$.

O fenômeno foi observado também na maior parte das usinas siderúrgicas e metalúrgicas dos estados do Rio de Janeiro e Minas Gerais, fazendo com que a participação do gás na siderurgia brasileira passasse de 1\% em 1980, para 2\% em 1990 e 6,4\% em 2009, enquanto que o óleo combustível correspondia a 11,8\% em 1980 e em 2009 era de apenas 0,8\% (EPE, 2010). Vale notar que, na siderurgia do Sudeste, o gás natural não penetrou como redutor, função ainda exercida pelo coque de carvão mineral, mas sim como fonte de calor.

De acordo com Oliveira (2006), ainda durante a década de 1990, a mais notável novidade foi o surgimento do consumo de gás natural fora dos setores de transformação. Muito tardiamente, o gás natural penetrou nesses mercados. São demandas tipicamente urbanas que só surgem no final da década de 1980 e aumentam de modo sustentado durante a primeira metade da década seguinte.

Entre 1996 e 1998, pode-se constatar uma ruptura nesta tendência de crescimento. Constata-se também que o consumo residencial cresceu com respeitável velocidade até 2009, embora esteja concentrado em apenas duas cidades (Rio de Janeiro e São Paulo). A expansão desta demanda foi responsável por parte significativa do incremento desta categoria de outros consumidores.

No Brasil, o incremento inicial da utilização do gás na petroquímica, assim como na própria indústria do petróleo, decorreu do menor custo de acesso ao energético e do 
benefício imediato auferido pelo seu aproveitamento. No caso da Petrobrás, todas as atividades estavam articuladas em uma mesma corporação e a capacidade de financiamento não era uma restrição para o conjunto de firmas, pelo menos até meados da década de 1980 (OLIVEIRA, 2006).

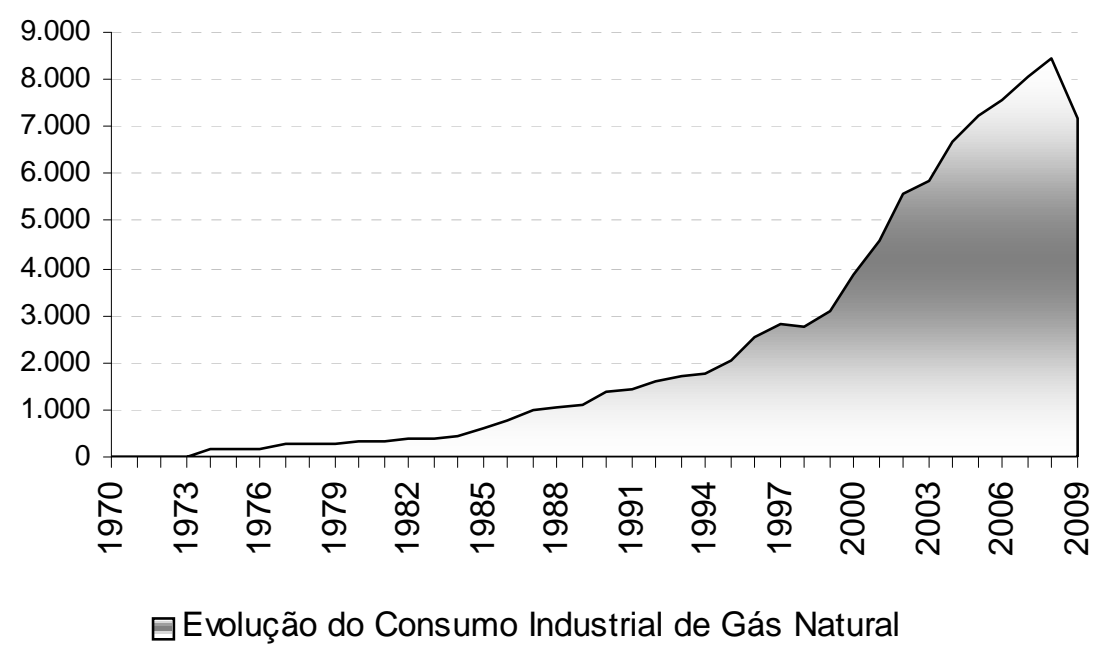

Figura 23 - Evolução do consumo industrial de gás natural ( $10^{3}$ TEP)

Fonte: (MME, 2012. Unidade $10^{3}$ tep)

\subsection{As Reservas de Gás Natural no Brasil}

As informações relativas às reservas de gás natural contidas neste capítulo são baseadas nos boletins mensais da ANP, de acordo com o regulamento técnico dessa entidade, respeitando as normas internacionais publicada pela "Society of Petroleum Engineers (SPE).

De acordo com a ANP (2012), denominam-se reservas os recursos descobertos de gás naturais comercialmente recuperáveis a partir de uma data de referência. A estimativa desses valores incorpora um certo grau de incerteza quanto às informações de geociências, engenharia e de natureza econômica.

Em função disso, as reservas podem ser classificadas como: 
_ Reservas Provadas - são aquelas que, com base na análise de dados geológicos e de engenharia, se estima recuperar comercialmente com elevado grau de certeza;

_ Reservas Prováveis - são aquelas cuja análise dos dados geológicos e de engenharia indica uma maior incerteza na sua recuperação quando comparada com a estimativa de reservas provadas;

_ Reservas Possíveis - são aquelas cuja análise dos dados geológicos e de engenharia indica uma maior incerteza na sua recuperação quando comparada com a estimativa de reservas prováveis; e

- Reservas Totais - representa o somatório das reservas provadas, prováveis e possíveis.

De acordo com ANP (2012), no período de 1964 a 2010, as reservas provadas de gás natural cresceram a uma taxa média de $8 \%$ a.a, devido a um esforço continuo e deliberado de diminuir a dependência petróleo. As principais descobertas ocorreram na Bacia de Campos (bacia sedimentar onde se encontra a maior concentração de campos gigantes do país, tais como Albacora, Marlim e Roncador), bem como na Bacia do Solimões (bacia sedimentar onde se encontram o Pólo de Urucu - local onde boa parte do gás é reinjetado, e a jazida de Juruá, ainda sem aplicação comercial).

A evolução das reservas de gás natural no país apresenta um comportamento muito próximo ao das reservas de petróleo, devido principalmente à ocorrência de gás natural sob a forma associada. Há, no entanto, a expectativa de que novas reservas de gás natural sejam descobertas, eminentemente sob a forma não-associada, tal como é sinalizado pelas descobertas recentes na Bacia de Santos (ANP 2012).

As principais descobertas ocorreram na Bacia de Campos, no estado do Rio de Janeiro e na Bacia do Solimões, no estado do Amazonas crescendo a uma taxa média de quase 10\% ano, entre 1964-2010 - sem contar as descobertas recentes do pré-sal. A evolução das reservas de gás natural no pais apresenta um comportamento muito próximo ao das reservas de petróleo, devido principalmente a ocorrência de gás natural sob a forma associada, gás natural encontrado, em reservatório, na companhia do petróleo, estando dissolvido no óleo ou sob forma de uma capa de gás. 


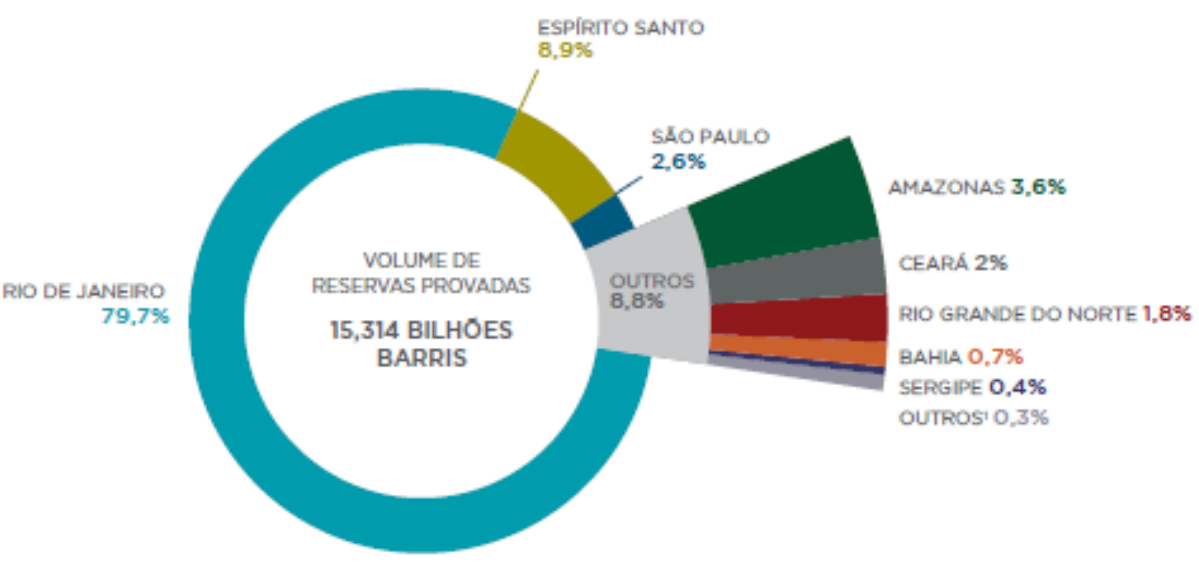

FONTE: ANP/SDP (Tabala 2.4)

NOTAS: 1. Inclul condensads.

2 Var am Notas Cerais tem sobre "Roservas Bras:leiras de Patrolep e Gas Naturar".

1'inclul Alagoas, Daraná o Santa Catarina.

Figura 24 - Volume de reservas provadas por estado da federação

Fonte: ANP (2013)

De acordo com dados ANP (2013), no final de 2012, as reservas totais de petróleo do Brasil foram contabilizadas em 28,6 bilhões de barris. Já as reservas provadas totalizaram 15,3 bilhões de barris, volume que representou 53,6\% das reservas totais. Das reservas provadas, $94 \%$ se localizavam no mar, com destaque para o Rio de Janeiro - que deteve $84,8 \%$ das reservas provadas offshore e 79,7\% do total. Em 2012, o Brasil ocupou a $14^{\mathrm{a}}$ posição no ranking mundial de países com as maiores reservas provadas de petróleo.

\subsection{A Produção e a Oferta de Gás Natural no Brasil}

Entre os anos de 1970 e 2012 a produção brasileira de gás natural cresceu, em media, $8 \%$ ao ano. Como comentado anteriormente, ocorreu um grande salto de produção na década de 1980, principalmente em decorrência do inicio de operação das jazidas da Bacia de Campos. 


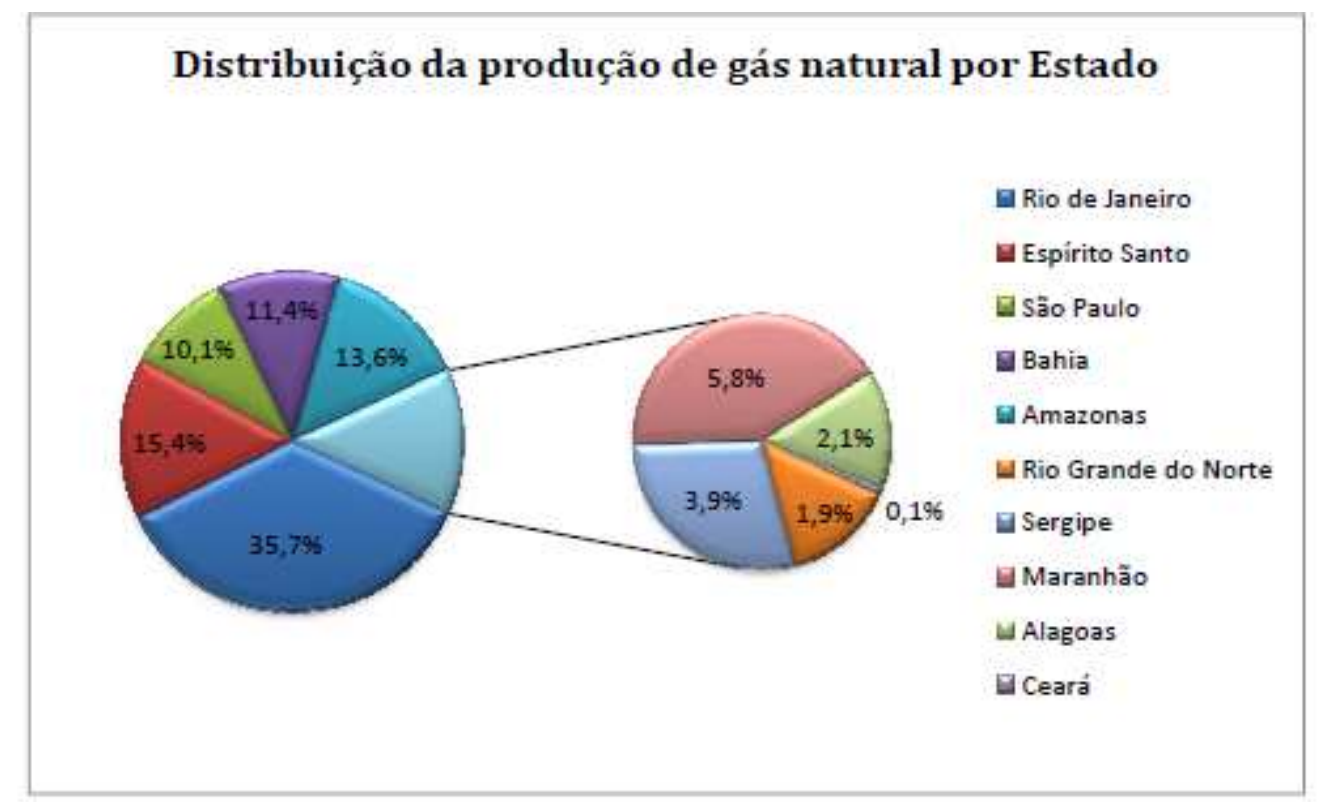

Figura 25- Distribuição da produção de gás natural por estado

Fonte: ANP (2013)

Em função da produção de gás natural no Brasil ser em grande parte associada e a infraestrutura nacional de transporte não possuir uma grande abrangência, este combustível e comumente queimado ou reinventado. Atualmente, a Petrobras e praticamente a única produtora e vendedora de gás natural as empresas distribuidoras no Brasil. E, de acordo com seu plano estratégico de negócios, o mercado brasileiro de gás natural tende a crescer a taxas superiores a 10\% ao ano ate 2017.

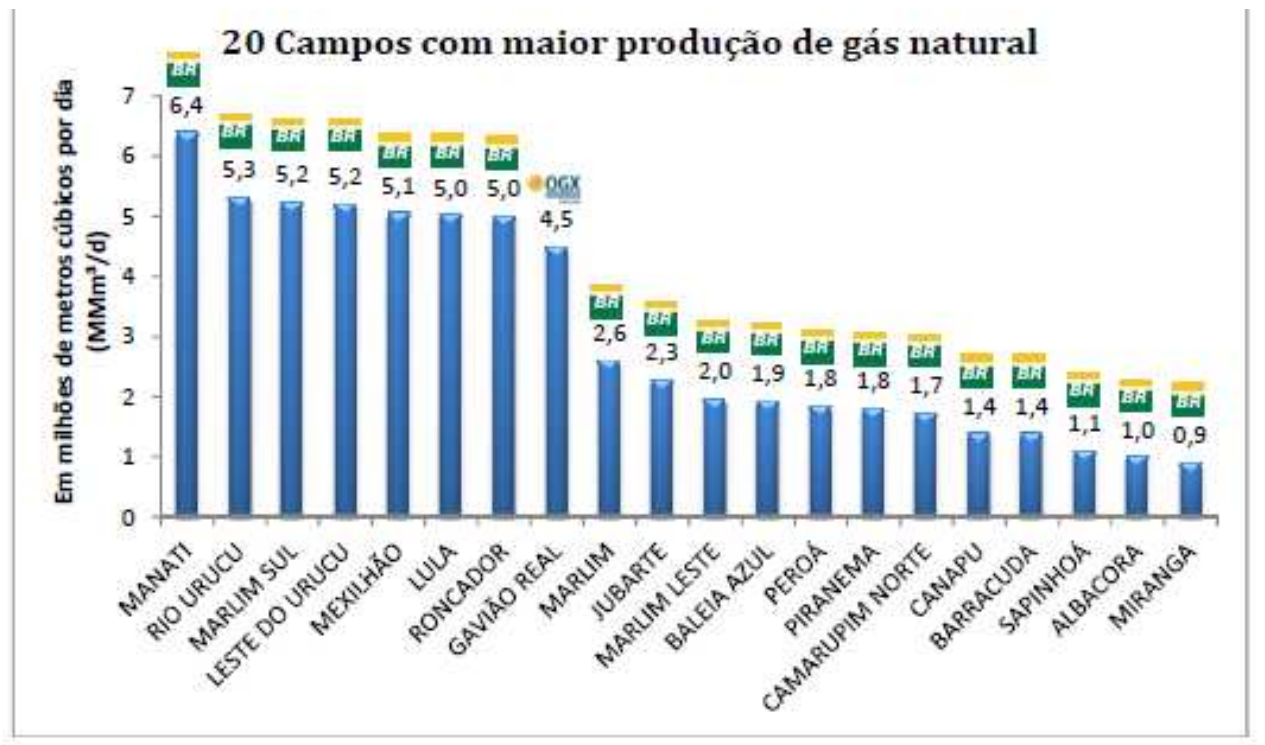

Figura 26 - Campos com maior produção de gás natural

Fonte: ANP (2013) 


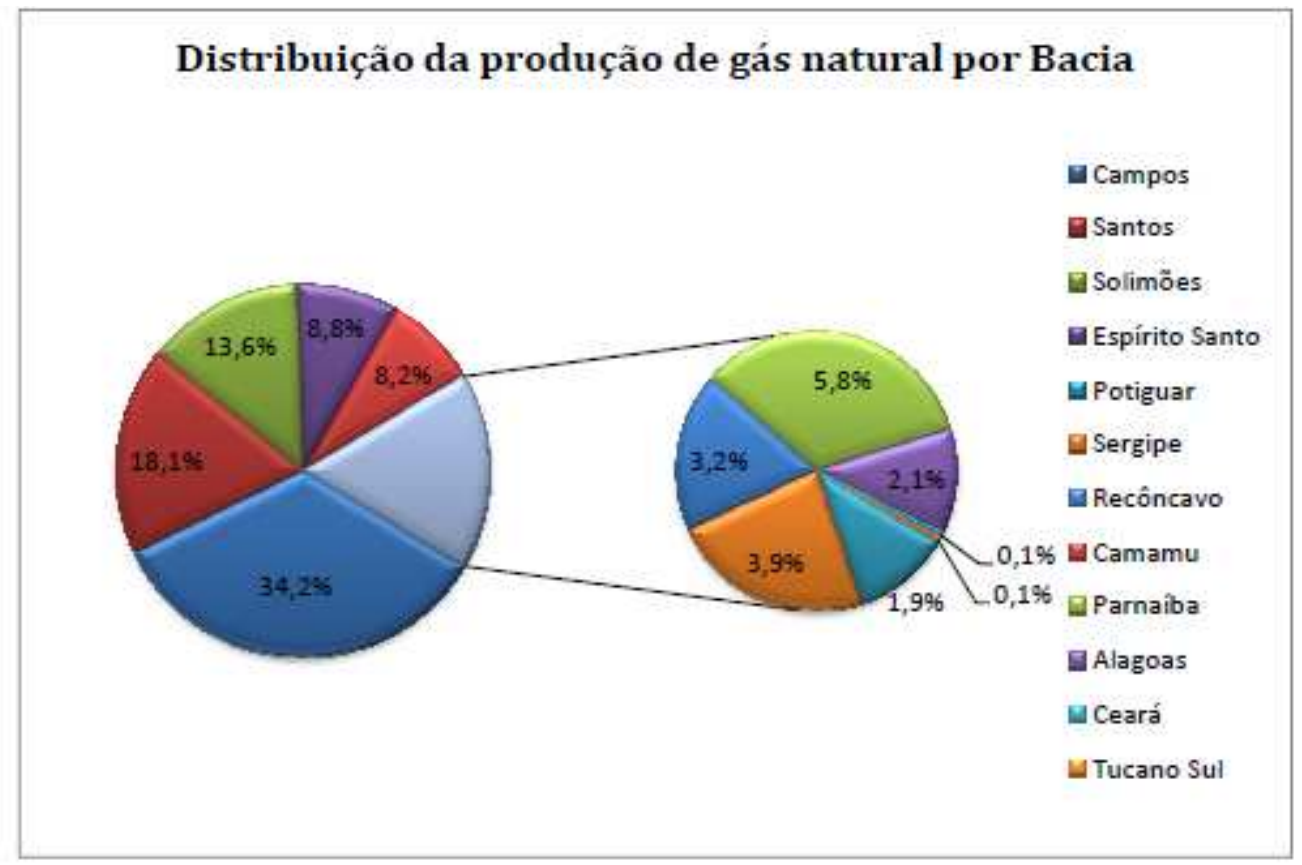

Figura 27 - Distribuição da produção de gás natural por bacia

Fonte: ANP (2013)

\subsection{A Importação de Gás Natural no Brasil}

Em agosto de 1999 iniciou o funcionamento do Gasbol permitindo um grande aumento de gás importado. Em julho de 2000, a companhia Sulgas, Companhia de Gás do Estado do Rio Grande do Sul. Responsável pela comercialização e distribuição de gás natural canalizado naquele estado, iniciou a importação de gás natural proveniente da Argentina.

Em 2001, a Empresa Produtora de Energia Ltda. iniciou a importação de gás boliviano destinado a usina termelétrica de Cuiabá, sendo este gás escoado pelo gasoduto Lateral Cuiabá. Já em setembro, a BG Comercio e Importação Ltda. iniciou a importação de gás natural boliviano, escoado pelo Gasbol e destinado a companhia distribuidora COMGAS, no Estado de São Paulo.

Em agosto de 2006, a Centro Oeste Gás e Serviços Ltda, empresa Prestadora de servicos de carregador e comercializador de gas natural no estado do Mato Grosso para fornecimento a consumidores de grandes quantidades e distribuidora local. 21, CGS, 
iniciou a importação de gás boliviano, destinado ao estado de Mato Grosso, em complemento ao volume importado pela EPE. Em dezembro de 2008, a MTGas Companhia Mato-Grossense de Gás. Responsável pela comercialização e distribuição de gás natural canalizado no estado do Mato Grosso

A Petrobras tem sido a única empresa a realizar importações de gás natural por meio de gasodutos. Isso acontece principalmente pelo corte de exportações de gás natural por parte da Argentina, que passou a enfrentar serias dificuldades para seu próprio abastecimento interno e pela indisponibilidade do gás boliviano, o qual já esta todo comprometido em contratos com a Petrobras e com a própria Argentina.

Tabela 1- Resumo produção e importação de gás natural no Brasil no ano de 2012

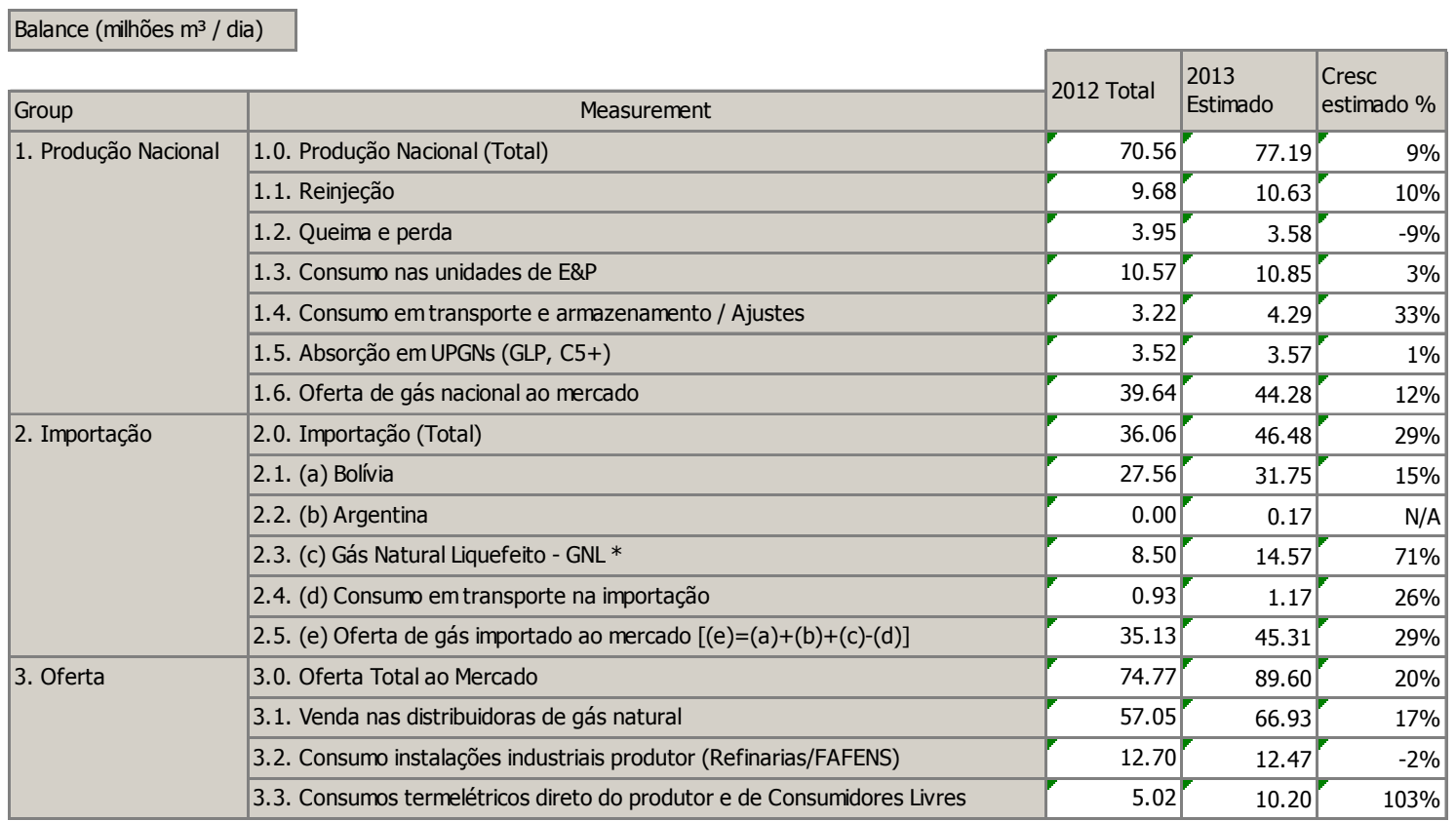

Fonte: IBP (2013)

\subsection{A Infraestrutura de Processamento de Gás Natural no Brasil}

O principal objetivo do processamento de gás natural e garantir a especificação do gás para os consumidores finais do produto. A capacidade nominal de processamento atual totaliza 66,5 milhões de metros cúbicos por dia. A capacidade instalada de processamento, na região nordeste, totaliza 24,5 de milhões de metros cúbicos por dia (36,8\% da capacidade brasileira). A região sudeste possui 30,1 milhões de metros 
cúbicos por dia (45,3\% da capacidade nacional). Já as regiões norte e sul 23 possuem capacidade de processar 9,7 (14,6\%) e 2,2 (3,3\%) de milhões de metros cúbicos de gás natural por dia, respectivamente. Na Tabela 2 e apresentada a capacidade nominal de processamento, por unidade produtora, existente no Brasil.

Tabela 2 - Capacidade nominal de processamento de gás natural existente

\begin{tabular}{lccc}
\multicolumn{1}{r}{ Estado } & Petróleo (bbl/d) & Gás Natural $\left(\mathrm{Mm}^{\mathbf{3}} / \mathbf{d}\right)$ & Produção Total (boe/d) \\
\hline Rio de Janeiro & 1.499 .618 & 27.874 & 1.674 .942 \\
Espírito Santo & 315.762 & 12.031 & 391.437 \\
São Paulo & 90.988 & 7.854 & 140.389 \\
Bahia & 45.345 & 8.937 & 101.559 \\
Amazonas & 28.236 & 10.665 & 95.319 \\
Rio Grande do Norte & 59.499 & 1.500 & 68.936 \\
Sergipe & 42.436 & 3.087 & 61.851 \\
Maranhão & 144 & 4.495 & 28.415 \\
Alagoas & 4.070 & 1.603 & 14.149 \\
Ceará & 7.844 & 98 & 8.463 \\
Total geral & $\mathbf{2 . 0 9 3 . 9 4 2}$ & $\mathbf{7 8 . 1 4 3}$ & $\mathbf{2 . 5 8 5 . 4 6 1}$ \\
\hline
\end{tabular}

Fonte: Boletim mensal do gás natural ANP (2013)

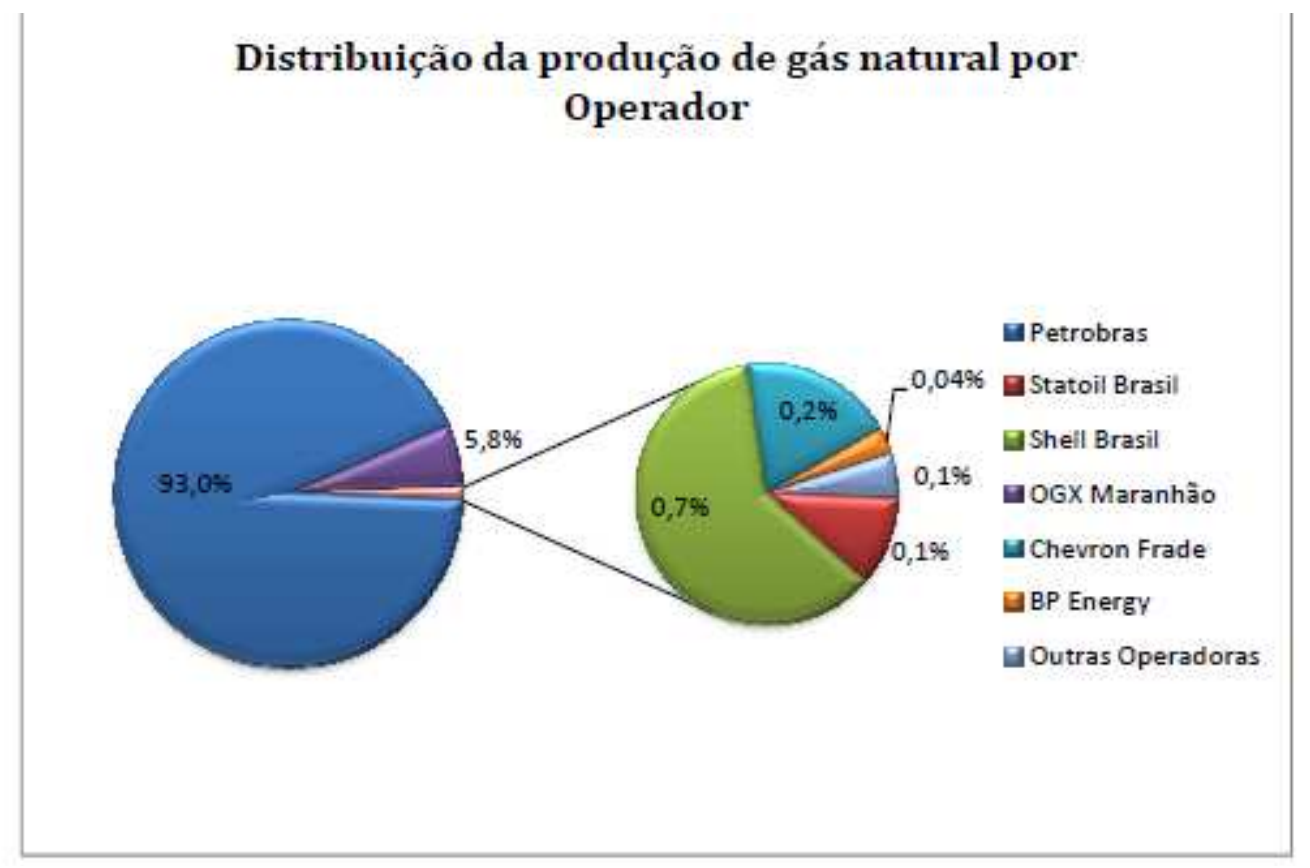

Figura 28- Distribuição da produção de gás natural por operador

Fonte: ANP (2013) 


\subsection{A Infraestrutura de Transporte de Gás Natural no Brasil}

Quando falamos em infraestrutura de transporte, devemos ter em mente as redes de gasodutos que transportam o gás natural desde os campos de produção ate os pontos de entrega às distribuidoras estaduais.

A rede brasileira atual e composta por uma malha que escoa gás natural de origem nacional e outra que escoa produto importado, totalizando cerca de $7.700 \mathrm{~km} \mathrm{de}$ extensão e 171,7 milhões de metros cúbicos por dia de capacidade de transporte. A Transpetro, empresa subsidiaria integral da Petrobras, opera $65 \%$ da extensão total da rede brasileira e o restante e operado pelas demais transportadoras atuantes no setor.

Apesar de ter apresentado um considerável aumento nos últimos anos, esta rede ainda e relativamente pequena e muito pouco ramificada, quando comparada com outros países consumidores de gás natural, e representam atualmente um importante gargalo para o maior desenvolvimento do mercado brasileiro de gás.

A Figura 29 traz a distribuição atual da rede de gasodutos existente ao longo do território brasileiro e aponta os novos projetos em estagio de implantação desenvolvidos no pais. 


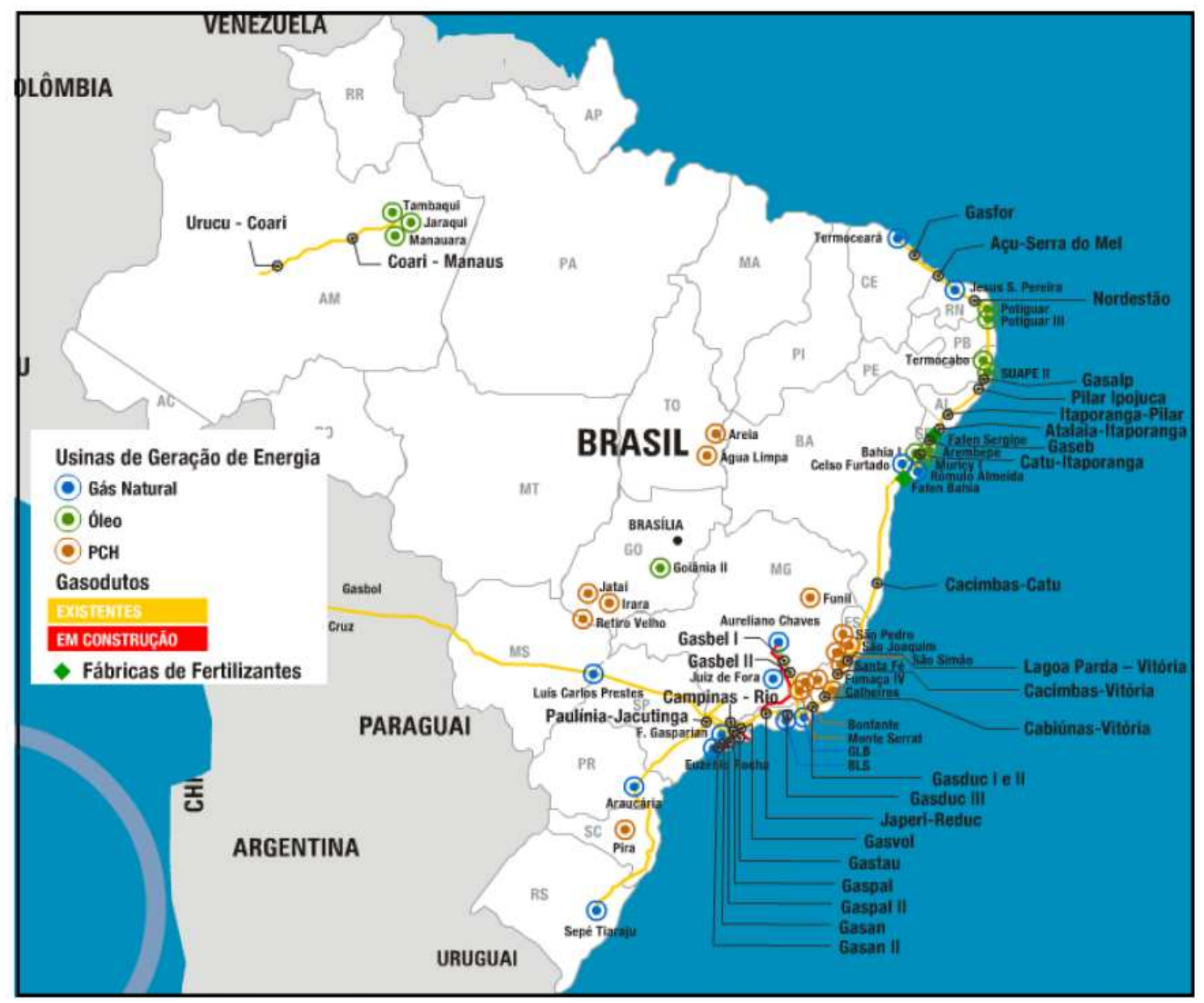

Figura 29 - Rede brasileira de gasodutos

Fonte: Petrobras (2009)

Como pode ser observado na figura, a região norte do país conta, por enquanto, com um único gasoduto ligando a região produtora de petróleo e gás de Urucu a capital Manaus, no Estado do Amazonas.

A região nordeste apresenta uma malha de gasodutos com uma extensão total de 1.924 $\mathrm{km}$, com diâmetros variáveis entre 8 a 26 polegadas. A região sudeste apresenta uma malha de gasodutos com uma extensão total de $2.512 \mathrm{~km}$, com diâmetros variáveis de 8 a 28 polegadas. A região sul apresenta uma malha de gasodutos com uma extensão total de 1.226,2 km com diâmetros que variam entre 16 e 24 polegadas. E, finalmente, a região centro-oeste apresenta uma malha de gasodutos com uma extensão total de $1.531,0 \mathrm{~km}$. 
Em seguida, abriremos um parêntesis para detalhar um pouco mais sobre o Gasbol, o qual tem grande importância política e estrutural na atual infraestrutura brasileira de gás natural.

\subsection{A Distribuição de Gás Natural No Brasil}

O sistema de distribuição de gás natural e, de acordo com a legislação vigente, exclusivo das distribuidoras estaduais de gás canalizado, o que implica na necessidade de investimentos por parte dessas empresas em redes de distribuição para a movimentação do produto desde os city-gates (estacoes de entrega do gás derivadas dos gasodutos de transporte) ate os pontos finais de consumo.

As atividades de distribuição são reguladas, em cada estado, por suas agencias reguladoras (ou pelo próprio estado, em caso de inexistência de agencias locais), as quais concedem as companhias estatais ou privadas o direito de comercialização, com exclusividade, do gás canalizado, nas áreas de concessão.

Nos dias atuais a demanda de gás natural das distribuidoras esta respaldada em contratos de longo prazo com a Petrobras. O modelo predominante de formação das distribuidoras de gás natural no Brasil foi o conhecido como tripartite, onde a companhia e constituída por três sócios, sendo um deles o governo Estadual, outro a Petrobras e o terceiro um ente privado. Existem exceções, como as distribuidoras puramente privadas dos estados do Rio de Janeiro e São Paulo, ou ainda as distribuidoras puramente estatais como a Sulgas (RS) e a Potigas (RN). Ha ainda aquelas cuja participação da Petrobras e maior que $30 \%$.

A Figura 30 mostra as áreas de concessão das companhias distribuidoras de gás natural no Brasil. 


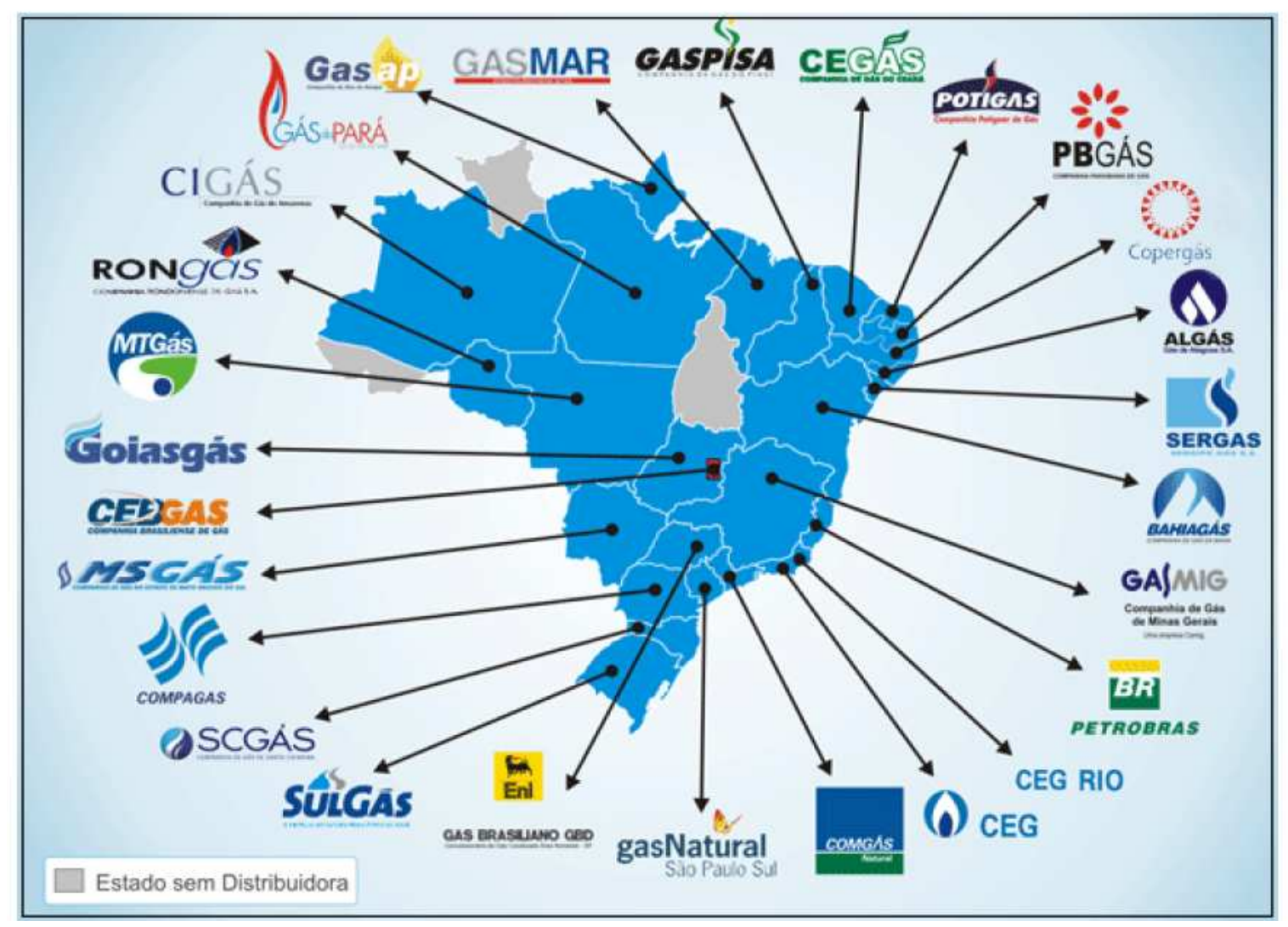

Figura 30 - Distribuidoras brasileiras de gás natural

Fonte: ABEGÁS (2012)

\subsection{A Precificação do Gás Natural no Brasil}

O preço do gás natural vendido às distribuidoras brasileiras e composto, fundamentalmente, por duas parcelas, uma referida como commodity, destinada a remunerar o produtor, e outra denominada tarifa de transporte, destinada ao serviço de movimentação do gás em gasodutos de transporte entre a produção e o consumo. Entretanto, atualmente, existem três formas distintas de se compor o preço final do gás natural no pais.

O gás natural oriundo de produção nacional e regulamentado pelos Ministérios da Fazenda e das Minas e Energia. Estes estabelecem o máximo preço de venda as empresas concessionarias distribuidoras de gás canalizado, o qual e oriundo do somatório do valor da commodity gás natural na entrada do gasoduto e a parcela referente ao transporte entre os pontos de recepção e entrega do combustível. Porem estas parcelas não são abertas e o preço final e divulgado como um valor único. 
O gás natural importado, destinado a distribuição local, tem seu preço de venda também composto por uma parte correspondente ao transporte e outra referente à própria commodity, entretanto, diferentemente, do anterior o preço final e, realmente, composto por essas duas parcelas.

Finalmente, ha ainda um preço especial para venda do gás natural destinado as usinas termelétricas incluídas no Programa Prioritário de Termeletricidade, o PPT. Neste caso ha um preço máximo de suprimento do gás natural destinado aos participantes do programa, independente da origem do gás (nacional ou importado).

A Tabela 3 mostra uma comparação entre os três preços acima mencionados, por região do pais, quando pertinentes, durante o mês de abril de 2012. No mercado da região sudeste, por exemplo, o preço do gás natural nacional, apresentado em parcela única, ficou em US\$ 9,7489 / MMBTU, já o gás importado da Bolívia, somando-se as duas parcelas de commodity e transporte, chegou a US\$ 7,3739 / MMBTU e o gás destinado às termelétricas do PPT ficou em US\$ 4,22 / MMBTU.

Tabela 3 - Preços do gás natural no Brasil (2009-2012)

\begin{tabular}{|c|c|c|c|c|c|}
\hline \multicolumn{2}{|c|}{ Value (US\$/MMBTU) } & \multirow{3}{*}{2009 Total } & \multirow{3}{*}{2010 Total } & \multirow{3}{*}{2011 Total } & \multirow{3}{*}{2012 Total } \\
\hline & & & & & \\
\hline Region & Source & & & & \\
\hline \multirow[t]{2}{*}{ Centro Oeste } & Importado & 6.78 & 8.33 & 10.13 & 11.75 \\
\hline & Nacional & - & - & - & - \\
\hline \multirow[t]{2}{*}{ Nordeste } & Importado & - & - & - & \\
\hline & Nacional & 8.18 & 10.22 & 12.14 & 12.82 \\
\hline \multirow[t]{2}{*}{ Sudeste } & Importado & $6.47^{\circ}$ & 7.37 & 8.94 & 9.87 \\
\hline & Nacional & $8.18^{\circ}$ & 9.92 & 11.80 & 12.54 \\
\hline \multirow[t]{2}{*}{ Sul } & Importado & $6.46^{\circ}$ & 7.37 & 8.93 & 10.42 \\
\hline & Nacional & - & - & - & - \\
\hline
\end{tabular}

Fonte: IBP (2013)

\subsection{Consumo Termoelétrico do Gás Natural no Brasil}

Enquanto o consumo de GN (para industrial, automotivo, uso residencial, etc) é praticamente constante, o consumo de gás para usinas térmicas é muito variável. A 
razão para isto é que o sistema elétrico brasileiro é predominantemente hidrelétrico ( $85 \%$ da capacidade de geração) e projetado para atender a demanda, mesmo se uma seca severa ocorre. Isso significa que usinas hidrelétricas são capazes, durante a maior parte do tempo de suprir as necessidades energéticas do Brasil.

O Operador Nacional do Sistema Elétrico (ONS), por isso, utiliza totalmente esta geração hidrelétrica adicional para reduzir produção de usinas térmicas, que são operados no modo de complementação produtiva hidrelétrica. Desta forma, os combustíveis fósseis são poupados e a consequência final de tais otimização hidrotérmica é a redução de custos para o consumidor.

Uma consequência importante dessa coordenação hidrotermal é a grande variabilidade de energia termoelétrica produzida a cada ano, o que pode variar de zero - se o usina térmica não for operada - até uma operação de base-load, em que a usina térmica opera em plena carga durante todo o ano. A regulamentação do setor elétrico exige que as usinas térmicas devam ter uma capacidade de fornecimento de gás e transporte disponibilidade adequadas para sua expedição com carga total para o ano todo (contrato de fornecimento de combustível sólido).

Desta forma, os produtores de gás natural têm que fazer um investimento importante em infraestrutura, o que pode, eventualmente, permanecer inativo durante muito tempo períodos. Se, por exemplo, uma usina termelétrica a gás é despachado apenas durante $40 \%$ do tempo, infraestrutura de gás permanece subutilizado por $60 \%$ do tempo. Assim, a atratividade de flexibilidade operacional de usinas a gás conflitos com a necessidade de recuperação do investimento para o gás setor.

A criação de contratos flexíveis para gás natural, onde o consumo pela indústria é reduzido quando a disponibilidade de gás diminui devido ao envio do gás plantas, traz oportunidades e desafios para os seus compradores (industriais). O grande desafio é como avaliar a atratividade de contratos flexíveis e seus preços. A disposição a um contrato flexível depende da frequência, gravidade e custo econômico de interrupções de fornecimento de gás, que são uma função de (i) A expedição termelétrica (variável estocástica); (ii) o preço da alternativa combustível, utilizado sempre que o fornecimento de gás é interrompido; e (iii) o perfil de risco do comprador contrato, que 
pode ser mais ou menos do avesso para o risco de ser interrompido e ter de usar um combustível alternativo mais caro.

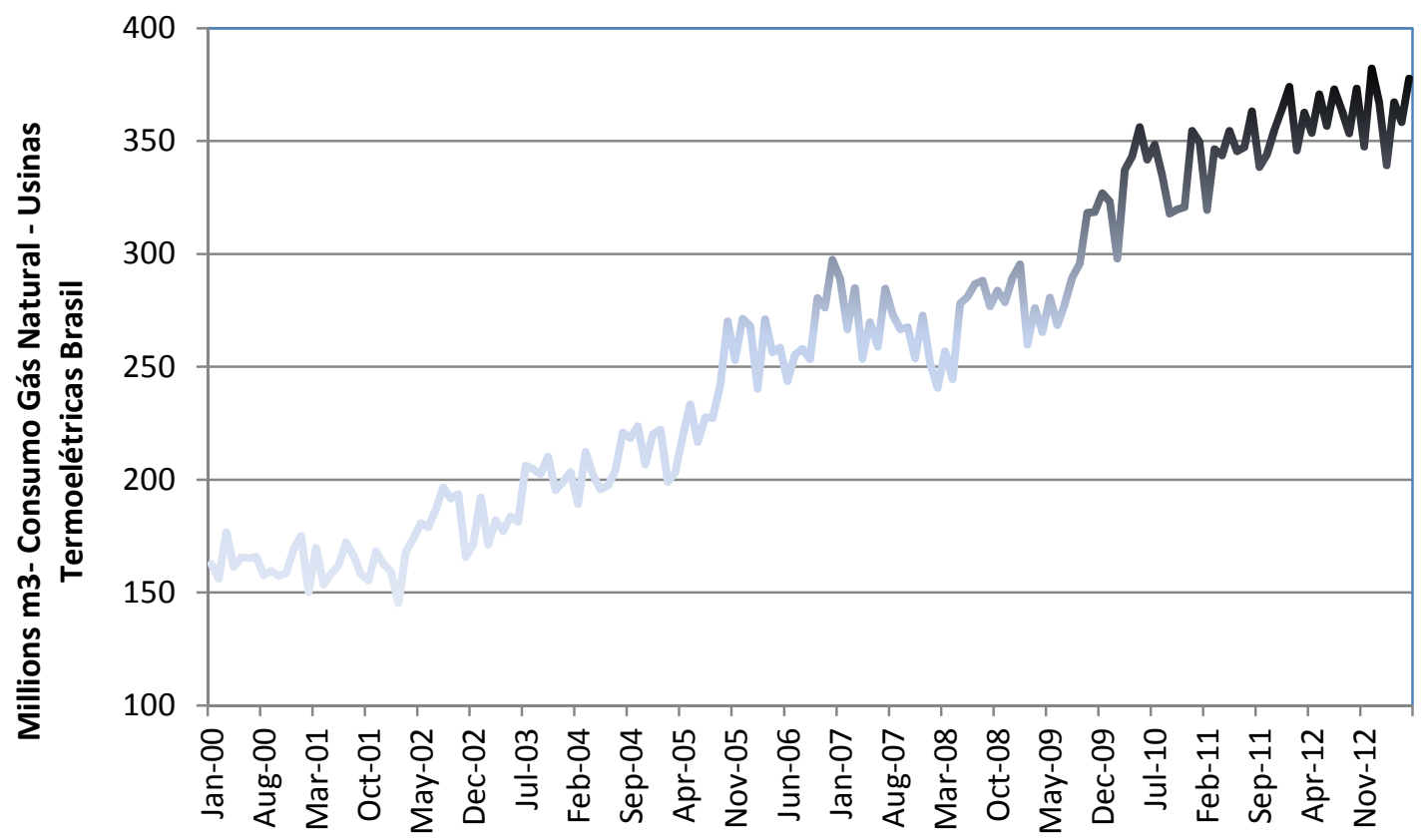

Figura 31 - Consumo de gás natural nas usinas termelétricas no Brasil

Fonte: IBP (2013) 


\section{MODELO ECONOMÉTRICO DE ESTIMATIVA DAS ELASTICIDADES PRECO E RENDA DO SETOR INDUSTRIAL BRASILEIRO}

Desde a década de 1970 a crise energética e os persistentes níveis elevados dos preços da energia, especialmente nos preços do petróleo, têm impactado a atividade econômica de várias economias em desenvolvimento. Como questão central da economia da energia surge a o debate sobre a relação entre o consumo de energia e as variações do PIB e quão determinante é a variável preço para um incremento ou redução deste consumo.

Diversos autores já abordaram a questão da demanda por energia - seja elétrica, gás natural, petróleo e seus derivados - com foco nas elasticidades preço e renda e na causalidade das variações do PIB com as variações do consumo de energia. No Brasil estudos com esta abordagem estão direcionados para a análise da demanda elétrica ou demanda por gasolina, sendo também o foco principal na elasticidade.

Embora a relação entre o consumo de energia e crescimento da produção tem sido um tema bastante estudado nas últimas três décadas, a evidência é ainda controversa. A literatura tem avaliado extensivamente a natureza da causalidade temporal entre o consumo de energia e o crescimento econômico e se a variável preço é crucial para o aumento ou diminuição do consumo. No entanto, as evidências empíricas dos estudos são mistas, variando de causalidade bidirecional ou unidirecional para não causalidade.

Neste capítulo, alguns destes estudos, artigos e trabalhos acadêmicos, serão revisitados. Estes se relacionam com esta dissertação principalmente por utilizarem modelos econométricos para chegarem a seus objetivos.

\subsection{Revisão da Literatura}

A literatura empírica fornece evidências mistas e conflitantes em relação ao consumo de energia e o crescimento do PIB. Esta discrepância de resultados é devida em grande parte ao uso de diferentes métodos econométricos e períodos de tempo, além de 
heterogeneidade específica de cada país, em condições de clima, desenvolvimento econômico e padrões de consumo de energia, entre outras coisas. Uma série de estudos recentes de séries de tempo tem examinado a direção da causalidade entre as duas variáveis em diferentes países, utilizando cointegração e várias abordagens de causalidade. Por exemplo, Yu e Choi (1985) para o Reino Unido, EUA e Polônia.

Análise da literatura pertinente destaca duas questões importantes. Primeiro, a evidência de causalidade entre consumo de energia e PIB e ou preço é mista e é menos específica varia muito dependendo do pais analisado. Como Lütkepohl (1982) indicou que exclusão de variáveis relevantes torna os resultados inconsistentes e frequentemente nenhuma relação causal pode ser encontrado entre o consumo de gás natural e crescimento econômico.

Em segundo lugar, os períodos de estimação não são atuais levando à falta de conhecimento sobre as relações entre as duas variáveis nos presentes de novos desenvolvimentos em perspectivas energéticas. Inclusão desta períodos de tempo é crucial para que a política apropriada pode ser sugerido. Por exemplo, devido à crise global e do desenvolvimento recente na agenda de mudança climática, a política de mistura de combustível drasticamente mudar e, portanto, sem a inclusão desta períodos de tempo, os resultados dos estudos anteriores pode ser menos exato.

Moroney (1992) argumenta que a energia é um fator de produção muito importante. As crises do petróleo na década de 70 e 80 revelaram isto. A influência é mais do que apenas o prejuízo de um PIB menor. Stern (1993) em sua extensa revisão da literatura enfatiza que o crescimento econômico não é apenas um produto de consumo de energia de entrada de fatores, mas o trabalho de entrada de capital e fatores também desempenham um papel importante. Ele argumenta que a agregação de mão de obra e energia é problemática. Ele não leva em conta as diferenças de qualidade no trabalho, que pode variar de empregos não qualificados para especialistas. Além disso, um Mtep (milhões de toneladas equivalentes de petróleo) do carvão, não pode ser tão eficiente quanto um Mtep de gás natural. Idealmente, as variáveis precisam ser desenvolvidas para explicar essas diferenças de qualidade no trabalho e energia. 
Stern (1993) mostra que a medida clássica do consumo de energia não dá indícios de causalidade, enquanto que sua medida não corrigida. Ele usa dados anuais durante o período de 1947.1990 para os EUA para estabelecer este resultado. Em um quadro semelhante Stern (2000) realiza uma análise de cointegração para concluir que a energia é um fator limitante para o crescimento, como os choques de energia tende a reduzir a produção.

Altõnay e Karagol (2004) aplica os testes de raiz unitária e testes de causalidade para verificar se existe relação causal entre o PIB e o consumo de energia para o período de 1950-2000. Estabelecer que o consumo de energia faz com que o PIB tem implicações políticas importantes, porque conclusão que tira-se é que uma redução no consumo de energia se traduzirá numa quebra no crescimento econômico. Enquanto eles mostram que a série de consumo de energia e o PIB da Turquia tem raiz unitária, eles também encontram uma quebra estrutural nos dados. Eles concluem que não há causalidade entre a energia e o PIB.

Al-faris (1997) teve como propósito estimar a elasticidade preço e renda na demanda por derivados de petróleo nos países que pertencem ao GCC (Gulf Cooperation Council - Conselho de Cooperação do Golfo: Bahrein, Kuwait, Omã, Qatar, Arábia Saudita e Emirados Árabes Unidos) separadamente no período de 1970 a 1991. O modelo foi estimado usando MQO, sendo que a equação considera como variável dependente a demanda por determinado produto em função do preço nominal do produto por barril, da renda nominal e da variável dependente defasada em um período (todas em $\log$ ). $\mathrm{O}$ resultado principal do estudo é que tanto o preço quanto a renda são inelásticos no curto prazo e que houve uma variação considerável nas elasticidades entre os combustíveis e entre os países.

Ramanathan (1999), através de técnicas de cointegração e correção de erros vetoriais (VEC), examina a relação entre a demanda por gasolina (per-capita), a renda nacional (per-capita) e o preço da gasolina na Índia no período de 1972 a 1994. O resultado obtido foi que a demanda por gasolina muito provavelmente crescerá dado um determinado crescimento no PIB, sendo este crescimento maior no longo prazo do que no curto prazo. Adicionalmente, a demanda por gasolina é relativamente inelástica à mudança no preço, tanto no curto quanto no longo prazo, e o modelo de correção de 
erros demonstrou que o ajuste na demanda por gasolina para o equilíbrio de longo prazo é feito de forma paulatina.

Azevedo (2007) em sua pesquisa teve como proposta analisar as elasticidades preço e renda e elasticidade cruzada entre os energéticos (álcool hidratado, óleo diesel, gasolina C, gás liquefeito de petróleo, óleo combustível e gás natural) no Brasil e nas suas regiões geográficas durante o período de janeiro de 2002 a junho de 2006, em bases mensais.

O modelo considera a demanda por determinado combustível como função do seu preço, do preço de outros combustíveis, da renda (a Produção Industrial do Brasil foi utilizada como uma proxy do Produto Interno Bruto para o cálculo da elasticidade renda) e da tendência. As metodologias de cointegração e correção de erros sugerida por Engle e Granger (1987) foram adotadas para calcular as elasticidades de curto e longo prazo, sendo feito um modelo para o Brasil e outro desagregado por regiões geográficas (método de estimação MQO). Nesta pesquisa, em nível nacional, os resultados mostraram que a demanda por álcool é inelástica em relação ao preço, a demanda por gás natural é inelástica em relação à renda.

Mattos e Lima (2005) estimaram a elasticidade renda e elasticidade preço para demanda de energia elétrica para o estado de Minas Gerais, eles utilizaram dados anuais de 1970 a 2002. Os valores encontrados foram 0,532 para a elasticidade renda de longo prazo e de -0,258 para a elasticidade preço de longo prazo. Em Mattos e Lima (2005), assim como em Modiano (1984), Andrade e Lobão (1997), Schmidt e Lima (2004) e Mattos (2005), foi adotado o modelo de demanda Cobb Douglas para as estimativas das elasticidades. Mattos e Lima (2005) utilizaram também o modelo de correção de erros vetoriais - VEC.

Schmidt e Lima (2004) têm como objetivo estimar a elasticidade preço e a elasticidade renda de longo prazo da demanda por energia elétrica nas três classes de consumo: residencial, comercial e industrial. Além disso, são realizadas previsões para o consumo de energia elétrica, vale ressaltar que esses autores não consideraram em suas estimativas a classes de "Outros" clientes, não sendo possível com isto estimar o total de demanda de energia elétrica. 
Montfort e Lise (2005) fizeram estudo para a Turquia com dados anuais de 1970- 2003, nele identificaram a relação entre consumo de energia e o PIB através de uma análise de cointegração. A análise feita por estes autores chega à conclusão que o consumo de energia e o PIB na Turquia são variáveis cointegradas. Montfort e Lise (2005) utilizaram o modelo de correção de erros para calcular a elasticidade-renda, chegando ao valor de 1,966 .

Comparando Schmidt e Lima (2004) com Montfort e Lise (2005) observa-se que ambos chegam à mesma conclusão, que consumo de energia e o PIB se cointegram. Entretanto, esses trabalhos apresentam enfoques um pouco diferentes, em que o primeiro trata da questão da cointegração somente para energia elétrica, já o segundo trata da questão utilizando dados de energia como um todo, incluindo consumo de petróleo, gás, carvão, eletricidade, entre outros.

Do ponto de vista metodológico, quatro gerações de contribuições podem ser identificadas. Estudos de primeira geração aplicado um auto-regressão vetorial tradicional modelo (VAR) na tradição de Sims (1972). Por exemplo, o trabalho seminal de Kraft e Kraft (1978), utilizando um modelo VAR, encontrou evidências em favor da causalidade correndo de renda para o consumo de energia nos Estados Unidos para o período 1947-1974. Além disso, os estudos sobre a primeira geração examinados no sentido de causalidade assumindo estacionaridade das variáveis subjacentes (ver, por exemplo, Erol e Yu , 1987, Yu e Choi , 1985; Abosedra e Baghestani , 1989).

Estudos de segunda geração foi responsável por não estacionariedade dos dados e realizada a análise de co-integração para investigar a relação de longo prazo entre o consumo de energia e crescimento. Esta segunda geração literatura, com base no procedimento de dois passos Engle e Granger (1987), os pares de variáveis estudadas para verificar a existência de relações de cointegração e utilizados modelos de correção de erro vetorial para testar a causalidade de Granger (por exemplo, Nachane et al . De 1988 ; Cheng e Lai , 1997; Glasure e Lee , 1998).

Estudos de terceira geração usavam estimadores multivariados no estilo de Johansen (1991). Abordagem multivariada de Johansen permite também mais de duas variáveis 
na relação de co-integração (ver, por exemplo, Masih e Masih, de 1997; Stern, 2000; Asafu - Adjaye , 2000; Soytas e Sari, 2003; Oh e Lee , 2004a , b).

Finalmente, os estudos de quarta geração empregam recentemente desenvolveu métodos econométrico para testar raízes unitárias e as relações de co-integração . Este estimativas da literatura modelos de correção de erros baseado em painel para realizar testes de causalidade de Granger (por exemplo, Lee, 2005; Al- Iriani , 2006; Mahadevan e Asafu - Adjaye , 2007; Lee e Chang , 2007, 2008 ; Apergis e Payne, 2009a , b; Lee e Lee, 2010; Costantini e Martini, 2010).

Os estudos realizados por Masih e Masih (1998), Asafu - Adjaye (2000), Fatai et al . (2004), bem como Mahadevan e Asafu - Adjaye (2007) levar o índice de preços ao consumidor (CPI) como proxy do preço da energia. No entanto, como a CPI não é conhecido por não capturar o preço da energia muito bem, foi então empregado o índice de preços de energia real, como Lee e Lee (2010) e Costantini e Martini (2010). Masih e Masih (1998) e Asafu - Adjaye (2000) anteriormente utilizado o modelo de correção de erros vetorial (VECM); Fatai et al. (2004) aplicaram o auto-regressivo defasagem distribuída (ARDL) abordagem; e Mahadevan e Asafu - Adjaye (2007), Lee e Lee (2010) como bem como Costantini e Martini (2010) usou uma especificação de correção de erro do painel de vetor para o modelo trivariado.

\subsection{Definições do Modelo Microeconômico}

Este trabalho teve na Teoria Microeconômica, especificamente na Teoria da Firma, como o referencial teórico para o estudo da demanda de gás natural uma vez que a energia não mais é um bem de consumo, mas um fator de produção que participa de atividades e processos produtivos. Se fosse a modelagem para o setor residencial utilizaríamos a teoria do consumidor, maximizando sua utilidade ao consumir energia.

\subsubsection{Teoria da Firma}

Conforme já antecipado, nos setor e industrial a energia não mais e um bem de consumo, mas um fator de produção. Não se trata, portanto, de um problema de 
maximização da utilidade do consumidor mas, sim, de uma escolha a ser feita pela firma, ou seja, qual a quantidade desse fator deve ser por ela utilizada.

Para responder a questões como essa, a Teoria da Firma parte do pressuposto de que toda empresa tem como objetivo principal a maximização do seu lucro. Segundo VARIAN (2003), o lucro de uma empresa pode ser definido como a diferença entre suas receitas e seus custos. Assim, se forem produzidos $n$ produtos $\left(y_{1}, \ldots, y_{n}\right)$, com preços $\left(p_{1}, \ldots, p_{n}\right)$, sendo utilizados $m$ insumos $\left(x_{1}, \ldots, x_{n}\right)$, com preços $\left(w_{1}, \ldots, w_{n}\right)$, o lucro desta empresa, comumente indicado por $\pi$, pode ser expresso como:

$$
\pi=\sum_{i=1}^{n} p_{i} y_{i}-\sum_{i=1}^{m} w_{i} x_{i}
$$

Para demonstrar como a firma deve proceder para maximizar seu lucro, supõe-se, por simplificação, que existem apenas dois insumos disponíveis, 1 e 2, sendo $x_{1}$ e $x_{2}$ as respectivas quantidades e $\mathrm{w}_{1} \mathrm{e} \mathrm{w}_{2}$ os respectivos preços. Supõe-se também que a função de produção da empresa seja dada por $\left(x_{1}, x_{2}\right)$ f $x_{1} x_{2}$, e ainda que apenas um produto $\mathrm{y}$, de preço $\mathrm{p}$, será produzido.

Outra consideração que necessita ser feita diz respeito à diferenciação entre o curto e o longo prazo. O curto prazo pode ser definido como aquele em que pelo menos um dos fatores e fixo, enquanto, no longo prazo, a firma pode variar a quantidade de todos os fatores, ate mesmo optar por utilizar zero unidade de cada um, ou seja, sair do mercado.

Iniciando pelo problema de maximização do lucro no curto prazo, supõe-se a quantidade $x_{2}$ mantida constante $\left(x_{2}\right)$, devendo a firma definir apenas a quantidade $\mathrm{x}_{1}$ a ser utilizada. Assim, o problema em questão pode ser apresentado da seguinte forma:

$$
\operatorname{Max} p f\left(x_{1}, \bar{x}_{2}\right)-w_{1} x_{1}-w_{2} \bar{x}_{2}
$$


Diferenciando (1) em relação a $x_{1}$ e igualando o resultado a zero, tem-se a condição de primeira ordem que deve ser respeitada para a maximização do lucro. A expressão (2) apresenta tal solução.

$$
p \cdot P M_{1}\left(x_{1}^{*}, \bar{x}_{2}\right)=w_{1}
$$

em que $P M 1$ é o produto marginal do fator $1 \mathrm{e} * \mathrm{x} 1$ é definido como a quantidade desse fator que torna máximo o lucro da firma.

A solução apresentada em (2) indica que, no curto prazo, a firma deve utilizar a quantidade $\mathrm{x}_{1}$ do fator até que o valor de seu produto marginal se iguale ao seu preço. Caso o valor do produto marginal do fator supere o seu preço (1) $\mathrm{p} \cdot \mathrm{PM}>w_{1}$, a firma pode aumentar seu lucro utilizando um pouco mais desse fator. Se o contrário ocorrer (p.PM1 $<w_{1}$ ), a firma deve reduzir a quantidade $\mathrm{x}_{1}$ para incrementar seu lucro. Assim, fica claro que apenas na condição dada por (2) o lucro da firma não pode ser acrescido, ou seja, é máximo.

Para mostrar como o problema de maximização enunciado em (2) é resolvido para o longo prazo, faz-se necessário apenas permitir que $\mathrm{x}_{2}$, até então considerada fixa, possa variar. Dessa forma, o problema (2) deve ser reescrito da seguinte forma:

$$
\operatorname{Max}_{x_{1}, x_{2}} p f\left(x_{1}, x_{2}\right)-w_{1} x_{1}-w_{2} x_{2}
$$

O resultado de (3) e basicamente o mesmo descrito em (2). Entretanto, deve ser respeitado para todos os fatores de produção, nesse caso, 1 e 2. Portanto, para que ocorra a maximização do lucro, os fatores devem ser empregados de maneira que:

p. $P M_{1}\left(x_{1}^{*}, x_{2}^{*}\right)=w_{1}$ 


\section{p.P. $M_{2}\left(x_{1}^{*}, x_{2}^{*}\right)=w_{2}$}

Ou seja, cada um dos fatores de produção deve ser escolhido de forma que o valor auferido pela firma com a venda de seu produto marginal se iguale ao preço desse fator.

As escolhas ótimas de cada fator como função do seu respectivo preço dão origem às curvas de demanda de fatores. Segundo VARIAN (2003), as curvas de demanda de fatores de uma empresa medem a relação entre o preço de um fator e a escolha maximizadora de lucros daquele fator.

\subsubsection{Aplicando a Teoria da Firma para Maximização de Lucro da Indústria}

A demanda por gás natural no segmento industrial pode ser descrita como um problema de minimização de custo, sujeito a um certo nível de produção. A demanda por gás natural é derivada da necessidade da firma fazer um determinado aparelho ou uma determinada máquina movida a gás funcionar. Portanto, a energia pode ser melhor interpretada como um fator que participa de processos ou atividades produtoras de bens.

Segue, então, segundo a teoria da firma a equação que pode melhor descrever o consumo de gás natural.

Assim, seja a seguinte função de demanda derivada por gás natural:

$$
C_{t}=k P^{\alpha}{ }_{t} Y^{\beta}{ }_{t} L^{\delta}{ }_{t} S^{\phi}{ }_{t}, k>0, \alpha<0, \beta>0, \delta<0, \phi>0, \vartheta<0
$$

Que tomando o seu logaritmo,

Chega-se na seguinte equação (6) linear de demanda por gás natural:

$$
\log C_{t}=\log k+\alpha \log P_{t}+\beta \log Y_{t}+\delta \log L_{t}+\phi \log S_{t}+\varepsilon \quad \text { Equação (6) }
$$

onde:

$C_{t}$ : é o consumo industrial de gás natural no tempo $t$; 
$P_{t}:$ é a tarifa de gás natural no tempo $t$

$Y_{t}$ : é a renda (PIBind) no tempo $t$;

$L_{t}$ : é o preço das máquinas e equipamentos industriais $t$;

$S_{t}$ : é o preço do bem substituto a gás natural no tempo $t$ (preço da energia elétrica no mercado livre).

$\mathcal{E}$ : incerteza, ou outras variáveis não captadas pelo modelo

Conforme função de demanda apresentada acima, aumentos na tarifa de gás natural, ceteris paribus, provocam redução na quantidade consumida, indicando relação inversa entre as duas variáveis. Tais alterações fazem com que os consumidores procedam de duas formas: alterando a utilização de equipamentos já existentes, ou adquirindo novos e mais eficientes equipamentos.

Utilizamos o PIB industrial (PIBind) como a variável que fornece os dados da renda para este modelo, assim, esta variável deve ser interpretada da seguinte forma: um aumento de PIBind impulsiona a demanda por produtos e um aumento de produção é necessário, seguido por um aumento de consumo de energia. Quando há aumento do PIBind, mantendo as demais constantes, ocorre mudança na restrição orçamentária das empresas permitindo um maior consumo de energia. Isso depende do estoque de equipamentos já existente, sendo alterado apenas a sua taxa de utilização. As indústrias também podem decidir pela aquisição de novos equipamentos, aumentando o estoque e, consequentemente, o consumo de gás natural.

O estoque de equipamentos assim como o crescimento da indústria influencia positivamente a demanda por gás natural. No curto prazo, esse estoque é considerado fixo, e a demanda restrita a alterações na sua faixa de utilização. No longo prazo, o estoque é flexível, podendo variar de acordo com alterações na renda (captada pela variável de PIB industrial), no preço dos equipamentos e em outros fatores (Mattos e Lima, 2005).

Existe uma especificidade em relação ao calculo dessa sensibilidade. Acontece também com outras empresas de utilities como agua e energia elétricaPor serem ofertadas e demandadas segundo tarifas que variam por blocos de consumo existem uma lista de 
preços de equilíbrio conforme a característica do demandante dificultando a especificação de suas demandas.

Um dos pontos mais discutidos na literatura microeconômica, que aborda a demanda por energia e a definição da variável preço. Alguns autores defendem o preço marginal enquanto outros autores defendem a utilização do preço médio. O preço marginal é o preço cobrado por unidade de consumo referente ao bloco onde recai a quantidade total consumida, enquanto o preço médio é obtido pela divisão do valor total pago pela quantidade total consumida (Silva, 2001).

Bjorner et al. (2001) defendem que, em geral, a utilização de preços marginais deve ser preferida ao uso de preços médios, uma vez que, sendo o preço médio função da quantidade consumida, este se torna uma variável endógena em vez de exógena.

Alguns estudos realizados para o Brasil tais como: Modiano (1984), Andrade e Lobão (1997), Braga (2001), Silva (2001), Schmidt e Lima (2004) utilizam a tarifa média nas estimativas da função de demanda. Os autores acreditam que essa variável é uma boa escolha para responder a alterações na quantidade demandada de energia.

Em concordância com esses autores, utilizou-se neste estudo a tarifa média de gás natural. Além disso, na função consumo está presente também, o preço médio do óleo combustível, por considerarmos que este seja um bem substituto ao gás para o segmento de consumo industrial.

A utilização da tarifa média de gás natural como variável da função consumo de gás natural traz algumas implicações sobre as estimativas das funções de demanda. Uma vez que há dependência recíproca entre a tarifa média e a quantidade consumida de gás natural, já que a tarifa para o segmento de consumo industrial, objeto deste estudo, é definida como uma função do próprio consumo, ou seja, quanto maior o consumo menor a tarifa paga pela indústria. Têm-se duas variáveis determinadas endogenamente no modelo, sendo que uma delas é um regressor.

Dessa forma, a possível simultaneidade entre as variáveis inviabiliza a utilização do método estatístico econométrico de mínimos quadrados ordinários, uma vez que a 
hipótese de ausência de correlação entre o termo de erro e o regressor e violada. No estudo de Nordin (1976) já fora constatado que, tanto nos modelos que utilizaram o preço em bloco como naqueles que usaram o preço médio para eletricidade, há o problema de simultaneidade.

Nessas circunstancias, de acordo com Schmidt e Lima (2004), existem duas metodologias: Modelos de Equações Simultâneas ou Técnicas e Cointegração. Neste trabalho optou-se por utilizar a segunda opção, mais precisamente mediante os procedimentos de estimação e os testes desenvolvidos por Johansen $(1988,1991)$ e ainda Johansen e Juselius (1990). Tal metodologia propõe a utilização do modelo Vetores Auto Regressivos (VAR), isto é, uma modelagem para estimar os vetores de cointegração.

A opção por esses modelos pode ser também justificada pelas propriedades estatísticas das séries temporais das variáveis analisadas, que, geralmente são séries não estacionárias. Segundo Gujarati (2000), uma série é estacionária se sua média e variância forem constantes ao longo do tempo e o valor da covariância entre dois períodos de tempo depender apenas da distância ou defasagem entre os dois períodos, e não do período e tempo efetivo em que a variância é calculada.

Durante muito tempo, a recomendação usual para se trabalhar com séries não estacionárias era que essas deveriam ser diferenciadas. Isso porque muitas séries econômicas são integradas de ordem 1 [I(1)], ou seja, têm uma raiz unitária, e portanto, tornam-se estacionárias na primeira diferença (Coelho, 2002).

Entretanto, de acordo com Enders (1995), esse procedimento restringe a análise a um contexto de curto prazo e, conforme ressaltado por Gujarati (2000), a maior parte da teoria econômica é enunciada como uma relação de longo prazo entre as variáveis na forma de nível, e não na forma de primeira diferença. Para análise de longo prazo entre variáveis não estacionárias, o procedimento mais adequado, quando aplicável, é o de cointegração. 


\subsubsection{A Elasticidade Preço e Renda}

Um conceito muito utilizado em estudos de demanda e o de elasticidade. Muitas vezes tem-se interesse em determinar a maneira como a quantidade demandada, seja de um bem, de um serviço ou de um fator de produção, responde a alterações nas variáveis relacionadas a essa demanda.

A elasticidade mede a proporcionalidade existente entre as variações que ocorrem nas quantidades e as variações provocadas em um fator qualquer, permanecendo todos os demais fatores constantes (ceteris paribus).

$$
E=\frac{\text { Variação \% na quantidade demandada }}{\text { Variação \% em qualquer det er min ante da demanda }}
$$

A Elasticidade Preço de Demanda e a descrição do grau de sensibilidade da demanda de um produto, face às mudanças no seu preço. Medição numérica:

$$
\begin{aligned}
& |E p d|=\frac{\text { Variação \% na quantidade demandada }}{\text { Variação \% no preço }} \\
& |E p d|=\frac{\frac{q_{1}-q_{0}}{q_{0}}}{\frac{p_{1}-p_{0}}{p_{0}}}
\end{aligned}
$$

Demanda elástica: Uma variação \% no preço provoca uma variação \% maior na quantidade demandada, ou seja, a expansão relativa das quantidades procuradas é mais do que proporcional à redução relativa dos preços.

Demanda inelástica: Uma variação \% no preço resulta numa variação \% menor na quantidade demandada, ou seja, a expansão relativa das quantidades procuradas é menos do que proporcional à redução relativa dos preços. 


\subsubsection{Cointegração}

Segundo Fava \& Cati (1995) a origem da discussão sobre a existência de raiz unitária nas séries econômicas está no debate sobre a estacionaridade ou não da tendência, sendo que grande parte dos dados utilizados na análise empírica em economia é em forma de uma série temporal. Uma série com uma tendência estocástica se diferencia de outra com uma tendência determinística, pois as mudanças na mesma deixam de ter um caráter transitório e passam a apresentar um caráter permanente [(Pereira, 1988) e (Gujarati, 2000)].

A presença de uma tendência estocástica implica que flutuações em uma série temporal são o resultado de choques não somente no componente transitório ou cíclico, mas também no componente de tendência. [Balke (1991) apud Gujarati (2000)]. Portanto, a determinação da presença de raiz unitária é relevante para a economia, pois auxilia no processo de verificação de várias teorias. Uma das aplicações dessa análise constitui-se na verificação da passividade das políticas econômicas. Além disso, a presença de raiz unitária pode ser utilizada como um indicativo de que os agentes econômicos possuem um comportamento racional, utilizando todas informações disponíveis [ver Pereira (1988) e Perron et al. (1995)].

A utilização dos modelos de regressão envolvendo séries temporais não estacionárias pode conduzir ao problema que se convencionou chamar de regressão espúria, isto é quando temos um alto $\mathrm{R}_{2}$ sem uma relação significativa entre as variáveis (Harris, 1995). Isto ocorre devido ao fato de que a presença de uma tendência, decrescente ou crescente, em ambas as séries leva a um alto valor do $\mathrm{R}_{2}$, mas não necessariamente, a presença de uma relação verdadeira entre séries (Gujarati, 2000).

Neste contexto, a importância da análise de cointegração surge de seu uso para aquelas séries econômicas não estacionárias. Basicamente, a presença de raiz unitária na série temporal conduz a resultados viesados, invalidando os pressupostos da estatística clássica de que a média e a variância são constantes ao longo do tempo, e, com isto, mascarando o relacionamento entre duas, ou mais, variáveis. Detectada a presença de raiz unitária, então se deve trabalhar com as séries temporais diferenciadas e não em nível, ou seja, a tendência precisa ser removida. Assim, quando uma série econômica 
apresentar uma tendência estocástica tornar-se-á estacionária após a aplicação de uma ou mais diferenças, pois terá pelo menos uma raiz unitária. No entanto, ao se remover a tendência, elementos de longo prazo entre as variáveis são eliminados.

A interpretação econômica da cointegração é que se duas (ou mais) variáveis possuem uma relação de equilíbrio de longo prazo, então mesmo que as séries possam conter tendências estocásticas (isto é, serem não estacionárias), elas irão mover-se juntas no tempo e a diferença entre elas será estável (isto é, estacionária). Em suma, o conceito de cointegração indica a existência de um equilíbrio de longo prazo, para o qual o sistema econômico converge no tempo (Harris, 1995).

O conceito de cointegração introduzido por Engle e Granger (1987) tem sido amplamente empregado na análise de séries temporais. A recomendação padrão diz que as séries não-estacionárias devem ser utilizadas em primeira diferença. No entanto, a cointegração quando aplicável, permite que regressões que envolvem esse tipo de variável sejam realizadas sobre seus níveis, sem que se incorra no problema da regressão espúria, além de não se perder informação de longo prazo, o que ocorre quando são utilizadas séries diferenciadas perdendo-se alguns graus de liberdade.

Engle e Granger (1987) procuraram mostrar que, apesar de duas (ou mais) variáveis serem não-estacionárias, é possível haver uma (ou mais) combinação linear entre elas que seja estacionária. Esse conceito, segundo Enders (1995), pode ser definido da seguinte forma:

Os componentes do vetor $X_{t}=\left(X_{1 t}, X_{2 t} \ldots, X_{n t}\right)$ são ditos cointegrados de ordem $d, b$, indicado por $X \sim C I(d, b)$ se:

a) Todos os componentes de $X_{t}$ são integrados. Uma série é integrada de ordem $d\left(y_{t} \sim\right.$ $I(d))$ se ela precisa ser diferenciada $d$ vezes para se tornar estacionária $\left(\Delta^{d} y_{t}\right.$ é estacionária). Assim, uma série estacionária é uma série $I(0)$, isto é, integrada de ordem zero. de ordem $d\left(X_{t} \sim I(d)\right)$;

b) Existe um vetor $\beta=\left(\beta_{1}, \beta_{2}, \ldots, \beta_{n}\right)$ tal que a combinação linear $\beta X_{t}=\left(\beta_{1} X_{1 t}+\beta_{2} X_{2 t}+\right.$ $\left.\ldots+\beta_{n} X_{n t}\right)$ é integrada de ordem $(d-b)$, sendo $b>0$. O vetor $\beta$ é chamado de vetor de 
cointegração. Para os trabalhos de ordem empírica, importa o caso particular $d=b=1$, tal que $\beta X_{t} \sim I(0)$.

O sistema de variáveis econômicas estará em equilíbrio de longo prazo quando $=\beta_{1} X_{1 t}$ $+\beta_{2} X_{2 t}+\ldots+\beta_{n} X_{n t}=0$. De modo geral, se $X_{t}$ possui $n$ variáveis, é possível determinar $r \leq n-1$ vetores de co-integração. O Agrupamento desses vetores em uma matriz dá origem a uma matriz $\beta$, de dimensão $r x n$, denominada matriz de cointegração (Verbeek, 2000).

O número de vetores de cointegração $(r)$ é igual ao número de vetores linearmente independentes e é conhecido como rank de cointegração. Entretanto, para qualquer escala $\lambda \neq 0$, a multiplicação $\lambda x \beta$ dará origem a um “novo vetor". De maneira similar, segundo Enders (1995), é comum utilizar uma das variáveis $\left(X_{t}\right)$ para normalizar o vetor $\beta$, fazendo seu coeficiente $\left(\beta_{t}\right)$ igual a 1 . Para tanto, é necessário apenas definir $\lambda=1 / \beta$.

\subsubsection{Dados Utilizados}

Os dados para estimação da demanda por gás natural, a princípio, poderiam ter duas periodicidades distintas: mensais ou anuais. Os dados mensais de consumo de gás natural estão disponíveis a partir de jan/2000 e os dados anuais a partir de 1970. Este estudo utilizará dados mensais devido a quebra estrutural no aumento de consumo ocorrido 1999/2000 no início do funcionamento Gasbol. A Tabela 4, a seguir, apresenta um resumo dos dados e das fontes utilizadas no trabalho.

Tabela 4 - Fontes e dados utilizados

\begin{tabular}{lll}
\hline Variável & Descrição & Fonte \\
\hline P & Tarifa Média Industrial em Valores Constantes de 2000 & ABEGÁS \\
& & Deflator IGP-DI \\
& & Banco de dados \\
S & Preço Energia Elétrica no Mercado Livre & Aries/IBRE/FGV/RJ \\
& & Deflator IPA-DI \\
L & IPA-OG- Máquinas e Equipamentos Industriais. Base: ano & Banco de dados \\
& 2000 = 100 & Aries/IBRE/FGV/RJ \\
Y & PIBpm - Preços Contantes de 2000 & Deflator IPA-DI \\
& & FGV/RJ \\
C & Consumo Total Industrial (mil m³/dia) & Deflator implícito do PIB \\
\hline
\end{tabular}

Fonte: Elaboração própria 


\subsubsection{Estimação das Elasticidades e Resultados Obtidos}

Para estimação da demanda foram aplicados logaritmos naturais aos valores observados das séries, com a finalidade de obter as elasticidades da demanda por gás natural como parâmetros da equação estimada.

Antes de realizar a análise de cointegração entre as diferentes séries utilizadas, verificou-se a estacionaridade destas séries. Para isso utilizou-se o teste de raiz unitária de ADF $(1979,1981)$. Pode-se encontrar este teste, como todo o procedimento de cointegração em Enders (1995) ou Hamilton (1994). Esta necessidade decorre do fato da análise de cointegração, geralmente, só ser válida para séries não-estacionárias e que possuam a mesma ordem de integração

De acordo com Rahbek e Mosconi (1999), mesmo que se tenha $N$ série não-estacionária de mesma ordem de integração em $M$ séries estacionárias $(M<N)$, os resultados dos testes de cointegração podem não se alterar.. Em geral, as séries econômicas são estacionárias em primeira diferença, tendo, portanto, ordem de integração igual a um. $\mathrm{Na}$ literatura, observamos que é aceitável uma ordem de integração de até 2 para séries econômicas.

O primeiro teste de estacionariedade aqui usado é o de Dickey-Fuller Aumentado (ADF). Um processo linear autorregressivo de ordem $p, A R(p)$, pode ser escrito como:

$A(L) y_{t}=\mu+\varepsilon_{t}$

Onde $\mathrm{A}(\mathrm{L})$ é um polinômio de grau $p$ no operador $L$, de lag:

$A(L)=1-\alpha_{1} L-\alpha_{2} L^{2}-\ldots-\alpha_{p} L^{p}$

O processo é estacionário se $A(L)$ tiver todas suas raízes fora do círculo unitário; se houver raiz dentro do círculo unitário, o processo é explosivo e evidentemente nãoestacionário. No entanto, se houver raiz sobre o círculo, ele é não-estacionário, mas não é explosivo. No caso do $A R(1)$ a raiz unitária corresponde ao processo: 


$$
y_{t}=\mu+y_{t-1}+\varepsilon_{t}
$$

que é um "passeio aleatório" com tendência determinística $\square$.

O teste $\mathrm{ADF}$ tem como hipótese nula a presença de raiz unitária no processo $A R(p)$.

Realizamos o teste de raiz unitária ADF para as séries selecionadas para o modelo. O resultado do teste será apresentado na Tabela 5, a seguir. O período das séries utilizadas foi de 1970 até 2012 e o pacote estatístico foi o Eviews 6.0.

Tabela 5 - Resultados do teste de raiz unitária ADF - Variáveis em nível

\begin{tabular}{cccccc}
\hline \multirow{2}{*}{ Variável } & Termos da equação & $\begin{array}{c}\text { Número de } \\
\text { defasagens }\end{array}$ & $\begin{array}{c}\text { Estatística de } \\
\text { teste (ADF) }\end{array}$ & \multicolumn{2}{c}{ Valor Crítico } \\
& & 0 & $-1,366$ & $-3,573$ & $-4,308$ \\
\hline $\mathrm{C}_{\mathrm{t}}$ & Constante e tendência & 0 & $-2,776$ & $-3,573$ & $-4,308$ \\
$\mathrm{P}_{\mathrm{t}}$ & Constante e tendência & 0 & $-3,440$ & $-3,567$ & $-4,308$ \\
$\mathrm{Y}_{\mathrm{t}}$ & Constante e tendência & 0 & $-2,865$ & $-3,567$ & $-4,295$ \\
$\mathrm{~L}_{\mathrm{t}}$ & Constante e tendência & 0 & $-2,569$ & $-3,567$ & $-4,295$ \\
$\mathrm{~S}_{\mathrm{t}}$ & Constante e tendência & 1 & & & \\
\hline
\end{tabular}

Nos resultados apresentados, a hipótese de presença de raiz unitária não pode ser rejeitada para nenhuma das 5 séries analisadas nem a um valor crítico de $5 \%$ nem de $1 \%$, o que indica que nenhuma delas é estacionária.

Para verificar a ordem de integração das séries, foram realizados testes ADF para as séries em primeira diferença. Do resultado obtido, em todos os casos, foi rejeitada a hipótese nula de presença de raiz unitária aos níveis de significância de $1 \%$ e $5 \%$. Conclui-se que todas as séries são integradas de ordem 1 I(1). Segue a Tabela 6, a seguir, com os resultados apurados. 
Tabela 6 - Resultados do teste de raiz unitária ADF - Variáveis em primeira diferença

\begin{tabular}{|c|c|c|c|c|c|}
\hline \multirow{2}{*}{ Variável } & \multirow{2}{*}{ Termos da equação } & \multirow{2}{*}{$\begin{array}{l}\text { Número de } \\
\text { defasagens }\end{array}$} & \multirow{2}{*}{$\begin{array}{l}\text { Estatística de } \\
\text { teste (ADF) }\end{array}$} & \multicolumn{2}{|c|}{ Valor Crítico } \\
\hline & & & & $5 \%$ & $1 \%$ \\
\hline $\mathrm{C}_{\mathrm{t}}$ & Constante e tendência & 0 & $-5,359$ & $-3,439$ & $-4,295$ \\
\hline$P_{t}$ & Constante e tendência & 0 & $-6,579$ & $-3,573$ & $-4,308$ \\
\hline$Y_{t}$ & Constante e tendência & 0 & $-4,588$ & $-3,567$ & $-4,308$ \\
\hline$L_{t}$ & Constante e tendência & 0 & $-5,895$ & $-3,573$ & $-4,308$ \\
\hline$S_{t}$ & Constante e tendência & 0 & $-5,255$ & $-3,567$ & $-4,308$ \\
\hline
\end{tabular}

Fonte: Elaboração própria

As escolhas do número de defasagens (coluna 3 da Tabela 7) e da inclusão ou não da constante e tendência (coluna 2 da Tabela 7) na série se deu da seguinte forma:

Primeiro definiu-se o número de defasagens. Para tanto, foi feito o teste ADF com um número grande de defasagens como $N=6$, por exemplo, e observou-se que a última defasagem era estatisticamente significativa. Caso fosse, o modelo teria $N$ defasagens, e caso não fosse, repetiria-se o teste com $N-1$ defasagens, e o mesmo procedimento seria realizado até encontrar o número correto de defasagens. Encontrado este número, partiu-se para a inclusão ou não da constante ou tendência. Para tanto, estimou-se a equação com o número de defasagens definido anteriormente e com constante e tendência. Caso a tendência fosse significativa, a equação conteria uma constante e uma tendência. Se a tendência não fosse significativa ${ }^{1}$, retiraria-se a tendência e a equação seria estimada novamente para observar se a constante seria significativa. Em caso positivo, esta ficaria no modelo. Em caso negativo, seria retirada.

Assim, parte-se para a verificação da cointegração entre as séries escolhidas, pelo modelo de Johansen, que faz uso de um VAR. Se as séries se cointegrarem, pode-se dizer que há uma relação de longo prazo entre elas e os coeficientes do vetor de cointegração serão as elasticidades de longo prazo da demanda por gás natural. Assim, define-se a especificação correta do VAR, na forma padrão, qual seja:

\footnotetext{
${ }^{1}$ A tendência é significativa ou não, segundo a tabela em Dickey e Fuller (1981), que pode ser encontrada em Enders (1995:223).
} 


$$
\left[\begin{array}{l}
C_{t} \\
P_{t} \\
Y_{t} \\
L_{t} \\
S_{t}
\end{array}\right]=\left[\begin{array}{l}
A_{10} \\
A_{20} \\
A_{30} \\
A_{40} \\
A_{50}
\end{array}\right]+\left[\begin{array}{l}
A_{11}(L) A_{12}(L) A_{13}(L) A_{14}(L) A_{15}(L) \\
A_{21}(L) A_{22}(L) A_{23}(L) A_{24}(L) A_{25}(L) \\
A_{31}(L) A_{32}(L) A_{33}(L) A_{34}(L) A_{35}(L) \\
A_{41}(L) A_{42}(L) A_{43}(L) A_{44}(L) A_{45}(L) \\
A_{51}(L) A_{52}(L) A_{53}(L) A_{54}(L) A_{55}(L)
\end{array}\right]\left[\begin{array}{c}
C_{t-1} \\
P_{t-1} \\
Y_{t-1} \\
L_{t-1} \\
S_{t-1}
\end{array}\right]+\left[\begin{array}{l}
e_{t}{ }^{C} \\
e_{t}{ }^{P} \\
e_{t}{ }^{Y} \\
e_{t}{ }^{L} \\
e_{t}{ }^{S}
\end{array}\right]
$$

Para especificação do modelo no que se refere ao número de defasagens, segundo Hendry (1995), deve-se partir do caso geral para o específico, Isto é, deve-se iniciar a análise com um grande número de defasagens e, a partir de testes formais, ir reduzindo o número de parâmetros. Utilizou-se os critérios de Akaike e Schuwarz ${ }^{2}$, como pode ser observado na Tabela 7, abaixo:

Tabela 7 - Definição do número de defasagens do VAR

\begin{tabular}{ccc}
\hline Defasagens & AIC & SIC \\
\hline 3 & 157,0457 & 102,2590 \\
2 & 144,9856 & 107,2685 \\
1 & 148,2366 & 132,0548 \\
\hline \multicolumn{3}{l}{ AIC = Akaike e SBC = Schwarz }
\end{tabular}

Fonte: Elaboração própria

Observa-se, também, na Tabela 8 que o número de defasagens do VAR dependerá do critério a ser adotado. Neste trabalho, optou-se por seguir o critério de Akaike, pois se perde menos graus de liberdade. Portanto, pode-se concluir que o VAR deve incluir 1 defasagem em cada uma de suas variáveis.

Quanto aos demais parâmetros do VAR, a constante e a tendência, estes foram definidos com base nos mesmos critérios utilizados para a definição do número de defasagens do VAR. O resultado dos testes foi que o melhor modelo deveria incluir uma constante e uma tendência no VAR, da seguinte forma:

\footnotetext{
${ }^{2}$ Enders (1995).
} 


$$
\left[\begin{array}{l}
C_{t} \\
P_{t} \\
Y_{t} \\
L_{t} \\
S_{t}
\end{array}\right]=\left[\begin{array}{l}
A_{10} \\
A_{20} \\
A_{30} \\
A_{40} \\
A_{50}
\end{array}\right]+\left[\begin{array}{l}
A_{11} A_{12} A_{13} A_{14} A_{15} \\
A_{21} A_{22} A_{23} A_{24} A_{25} \\
A_{31} A_{32} A_{33} A_{34} A_{35} \\
A_{41} A_{42} A_{43} A_{44} A_{45} \\
A_{51} A_{52} A_{53} A_{54} A_{55}
\end{array}\right]\left[\begin{array}{l}
C_{t-1} \\
P_{t-1} \\
Y_{t-1} \\
L_{t-1} \\
S_{t-1}
\end{array}\right]+\left[\begin{array}{l}
B_{11} B_{12} B_{13} B_{14} \\
B_{21} B_{22} B_{23} B_{24} \\
B_{31} B_{32} B_{33} B_{34} \\
B_{41} B_{42} B_{43} B_{44} \\
B_{51} B_{52} B_{53} B_{54}
\end{array}\right]\left[\begin{array}{l}
C_{t-2} \\
P_{t-2} \\
Y_{t-2} \\
L_{t-2} \\
S_{t-2}
\end{array}\right]+\left[\begin{array}{l}
B 10^{t} C \\
B 20^{t} C \\
B 30^{t} Y \\
B 40^{t} L \\
B 50^{t} S
\end{array}\right]+\left[\begin{array}{l}
e_{t}{ }^{C} \\
e_{t}{ }^{P} \\
e_{t}{ }^{Y} \\
e_{t}{ }^{L} \\
e_{t}{ }^{S}
\end{array}\right]
$$

Após determinar a melhor especificação do VAR, foi aplicado o modelo de Johansen, cujo objetivo era encontrar os vetores de cointegração. Para tanto, usou-se o teste do traço ( $\lambda$-traço), que indica não somente se há cointegração, mas, se houver, o número de vetores de cointegração existente. Os resultados podem ser vistos na Tabela 8 , a seguir:

Tabela 8 - Teste do $\lambda$-traço

\begin{tabular}{ccccc}
\hline \multirow{2}{*}{ Autovalor } & \multirow{2}{*}{ Estatística de Teste } & \multicolumn{2}{c}{ Valores Críticos } & \multirow{2}{*}{$\begin{array}{c}\text { Hipótese Nula № } \\
\text { Eq. Coint. }\end{array}$} \\
\cline { 3 - 4 } & & $5 \%$ & $1 \%$ & \\
\hline 0,6383 & 63,2549 & 52,14 & 62,17 & Nenhuma \\
0,5257 & 34,3259 & 35,57 & 44,57 & $\operatorname{Max} 1$ \\
0,2892 & 11,2575 & 18,66 & 25,87 & $\operatorname{Max} 2$ \\
\hline
\end{tabular}

Fonte: Elaboração própria

\subsubsection{Equação com as Elasticidades Obtidas - Resultados}

De acordo com os resultados acima, verifica-se que: na primeira linha, a hipótese de que não há vetores se cointegrando é rejeitada, tanto a $1 \%$ quanto a 5\%; na segunda, a hipótese de que há no máximo um vetor de cointegração não pode ser rejeitado aos dois níveis de significância escolhidos. Com isso, é identificada a presença de apenas 1 vetor de cointegração, cujos coeficientes desta equação podem ser escritos da seguinte forma: 
Tabela 9 - Coeficientes normalizados

\begin{tabular}{cccccrc}
$\mathrm{Ct}$ & $\mathrm{Lt}$ & $\mathrm{Yt}$ & $\mathrm{St}$ & $\mathrm{Pt}$ & tendência & $\mathrm{K}$ \\
\hline$-1,000000$ & $-0,425855$ & 0,882537 & $-0,096590$ & $-1,424588$ & 0,068475 & 2,145879 \\
& $(-0,08565)$ & $(-0,112585)$ & $(-0,00785)$ & $(-0,14584)$ & & \\
\hline${ }^{*}$ O número entre parênteses refere-se ao desvio-padrão & & &
\end{tabular}

Fonte: Elaboração própria

$C t=2,1458-1,42458 P_{t}+0,882559 Y_{t}-0,4258 L_{t}-0,0365 S_{t}+0,068 t+\varepsilon$

Lembrando que:

$C_{t}$ : é o consumo industrial de gás natural no tempo $t$;

$P_{t}$ : é a tarifa de gás natural no tempo $t$;

$Y_{t}$ : é a renda (PIBind) no tempo $t$;

$L_{t}$ : é o preço das máquinas e equipamentos industriais $t$;

$S_{t}$ : é o preço do bem substituto a gás natural no tempo $t$ (óleo e combustíveis lubrificantes).

$\varepsilon$ : incerteza, ou outras variáveis não captadas pelo modelo

Observamos através dos dados da Tabela 9 que para todos os coeficientes os testes mostraram que as variáveis são estatisticamente significantes e com os sinais de acordo com os esperados pela teoria. Além disso, a elasticidade-preço de longo prazo da demanda industrial tem o seu valor bem elevado $-1,42$, mostrando uma elasticidade unitária, marginalmente elástica, mostrando que a demanda é sensível à variação de preços do combustível. Uma elevação de preços faz com que o gás natural seja substituído por outra fonte energética.

Já a elasticidade-renda de $\mathbf{0 , 8 8 2}$, segundo a literatura é adequada, ou seja, o crescimento do consumo de gás natural é influenciado pelo crescimento agregado. Esperávamos encontrar uma variável com valor em torno de 1 e obtivemos este resultado. As elasticidades-preço de longo prazo das máquinas e equipamentos, 0,425, e dos combustíveis -0,0965 estão dentro do esperado. 


\section{CONCLUSÕES}

A presente dissertação procurou contribuir para estimações das elasticidades renda e preço da demanda por gás natural no Brasil da classe de consumo industrial. A escolha da classe de consumo industrial se justificou, conforme visto, por ela representar dois terços do consumo desse energético no país.

De forma geral, os estudos realizados sobre o cálculo das elasticidades preço e renda de energia estão fortemente centrados na análise da oferta e demanda por energia elétrica, ressaltando a diferença obtida nos resultados obtidos, principalmente em relação à elasticidade preço de demanda comparado a outros estudos realizados anteriormente.

As estimativas realizadas a partir da demanda por gás natural para o setor industrial indicaram valor de elasticidade-preço de $\mathbf{1 , 4 2}$, consideravelmente mais alto quando comparado a estudos prévios que indicam valores de elasticidade-preço da energia elétrica no país situados em torno de 0,80. Considerando o histórico e panorama da indústria do gás natural apresentado neste trabalho, acreditamos que este resultado esteja em linha com a demanda brasileira.

Uma vez que ao contrário da eletricidade na demanda residencial, por exemplo, a demanda por gás natural para o setor industrial apresenta-se bastante elástica. Isso significa que a demanda industrial por gás natural é muito sensível a alterações de preço relativo, ou seja, tanto do próprio gás natural, como do seu bem substituto, que no caso da indústria brasileira considera o preço da energia elétrica no mercado livre.

Para qualquer modelo de projeção de demanda, a variável renda é extremamente importante para consolidação do mesmo. Conforme visto, por definição microeconômica renda é a restrição orçamentária de um indivíduo ou firma, portanto variações da renda provocam variações no consumo. Em outras palavras, o chamado efeito renda é o efeito causado pela variação do poder aquisitivo. Entretanto, não se sabe de imediato qual o efeito da variação em uma unidade da renda no consumo de um determinado bem, porém, pode-se medir esse comportamento prévio ao longo de um período de tempo. 
Nesse contexto, o valor encontrado para elasticidade-renda foi de $\mathbf{0 , 8 8 2}$. Tal valor mostrou-se mais baixo quando comparado a outros estudos de estimativa de elasticidade preço e renda de demanda de energia, alguns desses estudos são: Modiano (1984), Andrade e Lobão (1997), Braga (2001), Silva (2001), Schmidt e Lima (2004), conforme visto em capítulo anterior. Deve-se destacar, entretanto, que a estatística ficou fracamente significativa, ressaltando mais uma vez a importância da variável preço frente à variável renda para alterações na demanda de gás natural por parte da indústria brasileira.

A queda na produção não conduz a uma redução correspondente no consumo de energia pelas ineficiências resultantes da baixa taxa de uso e pela própria inércia do consumo. No Brasil o crescimento do consumo da energia elétrica vem, há décadas, superando o do PIB. Para o gás natural, o crescimento da última década supera muito o crescimento do PIB no período. Dados da EPE (2012) mostraram que o PIB no período 2002-2012 cresceu $33 \%$, com um incremento médio anual de 3,4\%. Já o consumo de gás natural no Brasil no mesmo período cresceu $85 \%$ com um incremento médio de $9 \%$ aa. Portanto, o resultado obtido pelo modelo mostrou-se em linha com a evidência empírica.

Por último, cabe lembrar que existem outras variáveis que afetam a quantidade demandada de gás natural. Dentre elas destacam-se: despachos extraordinários de usinas termelétricas para suprir a demanda de energia elétrica em épocas de chuvas escassas. Este trabalho procurou destacar que reconhecendo a importância dos demais fatores sobre a demanda e oferta de gás natural no país, os resultados obtidos reforçam a importância da variável preço, uma vez que o gás natural no Brasil principalmente para o segmento Industrial é uma fonte de energia substituta.

Como possíveis extensões do presente trabalho, algumas sugestões podem ser feitas. Uma vez que esta análise centrou-se na demanda de gás natural para o setor industrial, novos estudos poderão incorporar os demais segmentos de consumo tais como: o automotivo, o residencial, a geração elétrica, entre outros.

Outra sugestão seria a realização de estudo das elasticidades das subdivisões do segmento industrial, aqui analisados em conjunto. Dentre essas subdivisões destacam-se 
as indústrias: de cimento, de ferro gusa e aço, de ferro ligas, de não-ferrosos, de química, de alimentos e bebidas, de papel e celulose, entre outras. Destaca-se que essas são indústrias para as quais o gás natural tem tido uma importância crescente no Brasil. 


\section{BIBLIOGRAFIA}

AGÊNCIA REGULADORA DE SANEAMENTO E ENERGIA DO ESTADO DE SÃO PAULO - ARSESP Metodologia para revisão tarifária das concessionárias de gás canalizado. Agosto, 2003. (Nota Técnica, ${ }^{\circ} 1$ ) Disponível em: <http:// www.arsesp.gov.br.>.Acesso em 30 mai. 2012.

ALENCAR, R.C,. BROEDEL, A. L. Disclosure and cost of equity in emerging markets. In: $8^{\circ}$ Encontro Brasileiro de Finanças, Rio de Janeiro, 2008.

ALLEN, F., PERCIVAL, J. Andar na crista da onda pode ser fácil mas...In: DOMINANDO finanças. São Paulo: Pearson Makron Books, 2001.

ANUATTI NETO, F,; SANTOS, E. M. dos; FERREIRA, D.; PEANO, C. R.. Desafios da regulação do mercado de gás natural no estado de São Paulo. In: RIO OIL \& GAS EXPO AND CONFERENCE. Rio de Janeiro. Proceedings. Rio de Janeiro: IBP, 2006. p.IBP 1437/ 1-10.

.; PELIN, E. P.; PEANO, C. R. O Papel do fator $x$ na regulação por incentivos e a conciliação com a manutenção do equilíbrio econômico-financeiro. São Paulo: FIPE/USP, 2004. Contribuição enviada para ANEEL referente à AP n ${ }^{\circ}$ 43/2003.

ASSAF NETTO, A. Finanças Corporativas e valor. São Paulo: Atlas, 2003.

ASSOCIAÇÃO BRASILEIRA DAS EMPRESAS DISTRIBUIDORAS DE GÁS CANALIZADO - ABEGAS. Disponível em: $<$ http://www.abegas.gov.br $>$. Acesso em 30 mai. 2012.

COMPANHIA DE DISTRIBUIÇÃO DE GÁS DA BAHIA - BAHIAGÁS. Disponível em: <http://www.bahiagas.gov.br>. Acesso em 28 ago. 2012.

BASTOS, N. Avaliação de desempenho de bancos brasileiros baseada em criação de valor econômico. Revista de Administração, São Paulo: FEA/USP, v.34, n3, jul./set.1999.

BALANÇO ENERGÉTICO NACIONAL - BEN - 2008: Ano base 2007. Relatório Preliminar. Brasília: Ministério de Minas e Energia, 2007. 
BANCO CENTRAL DO BRASIL - BACEN. Disponível em: 〈http://www.bcb.gov.br〉 Acesso em 16 jun. 2012.

BEN - Balanço Energético Nacional. 2012. Disponível em:

<https://ben.epe.gov.br/downloads/Relatorio_Final_BEN_2012.pdf>.

Acesso em: 20 out. 2012.

BOLSA DE VALORES MOBILIÁRIOS DE SÃO PAULO - BOVESPA: Disponível em: <http:www.bovespa.com.br>.: Acesso em 15 ago.2008.

BECKER, G. S. A Theory of competition among pressure groups for political influence. Quarterly Journal of Economics v. 98, Aug. 1983.

BEESLEY, M. E., LITTLECHILD, S. C. The regulation of privatized monopolies in the United Kingdon. . Journal of Economics, v. 20, n.3, Aut.1989.

BERG, S.V., TSCHIRHART, J. Natural Monopoly Regulation: principles and practice. Cambridge: Cambridge University Press, 1988.

BREALEY, R., MYERS, S. Principles of corporate finance. New York: McGrawHill, 2003.

CAMACHO, F., ROCHA, K., FIUZA, G. Custo de capital de distribuição de energia elétrica : revisão tarifária 2007 - 2009. Revista do BNDES, Rio de Janeiro, v. 13, p.231- 268, jun. 2006.

. Custo de capital de indústrias reguladas no Brasil. Revista do BNDES, n.21, p. 139-163, 2004.

CAMACHO, F. Regulação da indústria de gás natural no Brasil. Rio de Janeiro: Interciência, 2005.

RELATÓRIOS ANUAIS Rio de Janeiro: CEG, 2003-2007.

COASE, R. The Nature of the Firm. Oxford: Oxford Univ. Pres., 1937. 
COMPANHIA PARANAENSE DE GÁS - COMPAGÁS. Disponível em:

<http://www.compagas.com.br>. Acesso em 01 jun 2008.

COPELAND, T., KOLLER, T., MURRIN, J. Valuation: measuring and managing the value of companies. New York: John Wesley \& Sons, 1995.

COMPANHIA DISTRIBUIDORA DE GÁS DE SÃO PAULO - COMGÁS. Relatório

Anual, 2007. Disponível em:< http://www.comgas.com.br>. Acesso em 01 mai. 2012.

COMPANHIA DISTRIBUIDORA DE GÁS DE SÃO PAULO - COMGÁS.

Demonstrativos Financeiros de 2002-2007. Disponível em:

<http://www.comgas.com.br.> Acesso em: 01 mai. 2012.

COMISSÃO DE VALORES MOBILIÁRIOS - CVM. Disponível em:

<http://www.cvm.com.br> : Acesso em 15 ago. 2012

DAMODARAN, A. Investments valuation: tools and techniques for determining the valueof any assets. New York: Wiley, 2002.

Measuring company exposure to country risk: theory and

practice.New York: Stern School of Business. Working Paper, set. 2003.

EHRBAR, A. EVA: Valor Econômico Agregado. A verdadeira chave para a criação de riqueza. Rio de Janeiro: Qualitymark, 1999.

.The real key to creating wealth. New York: John Wiley \& Sons, 1998. ESTRADA, The cost of equity in emerging markets: a downside risk approach. Emerging Market Review . Fall, pp. 19-30, 2000.

The cost of equity in emerging markets: a downside risk approach II.

Emerging Market Review, Spring, pp. 67-73, 2001.

FIANI, R. Teoria da Regulação Econômica: estado atual e perspectivas futuras. Rio de Janeiro: UFRJ-IE, 2002.

GARCIA et al. Governança corporativa e performance empresarial: um estudo envolvendo empresas brasileiras com ações negociadas na Bovespa. São Paulo: Universidade Presbiteriana Mackenzie, 2005. 
GOLDBERGER, V. P. Regulation and Administered Contracts. The Bell Journal of Economics, v. 7, n.2, pp. 426-448. Autumn, 1976.

GÓMES-LOBO, A., Vargas, M. La Regulación de las Empresas Sanitarias en Chile: uma revisión critica. Revista Perspectivas, v. 6, n. 1, pp. 89-109, 2002.

GORDON, M. The investing, financing, and valuation of the corporation. Homewood:Irwin, 1962.

GREEN, R., PARDINA, M. Resetting price controls for privatized utilities: a manual for regulators. Washington: The World Bank Institute, 1999.

GROUT, P., ZALEWSKA, A The impact of regulation on market risk .Journal of Financial Economics, v.80, n1, pp.149-184, Apr., 2005.

GUSMÃO, M. B. de. Além do Custo de Capital. Revista Capital Aberto. v.1, n. 10, jun. 2004.

KAPLAN, R.; NORTON, D. Organização orientada para a estratégia: como as empresas que adotam o balanced scorecard prosperam no novo ambiente de negócio. 5 . ed. Rio de Janeiro: Campus, 2001.

KLOTZLE, M. C.; SILVA, F. M. "Governança corporativa e performance empresarial no Brasil”, Revista de Economia e Administração, São Paulo, v.2, n. 4, pp. 22-46, out./dez.2003.

KPMG. KPMG'S Corporate Tax Rates Survey, EUA: January 2004. Disponível em: <http://www.us.kpmg.com/microsite/global_tax/ctr_survey/2004CTRS.pdf $>$ Acesso em 30 jun. 2008.

LAMEIRA, V. J. Governança corporativa. Rio de Janeiro. Forense Universitária, 2001.

LAFFONT, J.; TIROLE, J. A Theory of Incentives in Procurement and Regulation. Cambridge: MIT Press, 1993.

LEVY, B.; SPILER, P. Regulations, Institutions, and Commitment in Telecommunications. A Comparative Analysis of Five Country Studies. In: Annual Bank Conference on Development Economics, 5. 1993. Proceedings. Washington: World Bank, 1993. 
LITNER, J. The valuation of risk assets and the selection of risky investments in stock portfolios and capital budgets. Review of Economics and Statistics, v. 47, n.1, p. 1337, Fev. 1965.

LODI, J. B. Governança corporativa. Rio de Janeiro: Campus, 2000.

LOWRY, M. N.; Kaufmann, L. Performance-Based Regulation of Utilities. Energy Law Journal, v. 23, n. 2, p. 399-457, 2002.

MALVESSI, O. Criação ou destruição de valor ao acionista. Conjuntura Econômica, Rio e Janeiro, vol. 54, n.1, jan. 2000.

MARQUES, F. R. et al. Evolução da geração de valor da Petrobras no período pósmonopólio. Petro \& Química, v.30,n.288, pp. 94-96, 2006.

; PARENTE, Virginia. A geração de valor no setor de distribuição de gás no Brasil. In: RIO OIL \& GAS EXPO AND CONFERENCE. Rio de Janeiro.

Proceedings. Rio de Janeiro: IBP, 2006. p.IBP 2023 / 1-6.

MARTELANC, R.; PASIN, R.; CAVALCANTE, F. Avaliação de empresas: um guia para fusões \& aquisições e gestão de valor São Paulo: Pearson, 2005.

MARTIN, J. D. , PETTY, J. W. Gestão baseada em valor: a resposta das empresas à revolução dos acionistas. Rio de Janeiro, Qualitymark, 2004.

McCORMACK, J., WYTHEESWARAN, J. How to use EVA in the oil and gas industry. Journal of Applied Corporate Finance v.11, n.3, p. 109-131, 1998.

MINISTÉRIO DE MINAS E ENERGIA. Plano decenal de energia elétrica 20112021. Brasília: EPE, 2012.

MONERRY, N. Motivações para gerenciar o valor. São Paulo Dominando Finanças: Makron Books, 2002.

MOSSIN, J. Equilibrium in a capital asset market. Econometria, v.34, n.4, p. 768-783, 1966.

SANTOS, E.M.; CARRERA Z., G.; DONDERO V., L. Z.; FAGA, M., T., W. Gás natural: estratégias para uma energia nova no Brasil. São Paulo: 
Annablume, 2002.

MONTEIRO, E. M. R. Teoria de grupos de pressão e uso político do setor_elétrico brasileiro. 2007. 140p. Dissertação (Mestrado em Energia). Programa Interunidades de Pós-Graduação em Energia da Universidade de São Paulo, 2007

PARENTE, V. (Cord.). Energia: o desafio das agências reguladoras. São Paulo: Instituto Acende Brasil, 2007. Disponível em: http://www.acendebrasil.com.br/archives/files/estudos//20070213_USP_Acende_Agenc ias_Integral.pdf. Acesso em 03 jun. 2012.

PARENTE, Virgínia, et al. Offshore decommissioning issues: Deductibility and transferability. Energy Policy, Volume 34, Issue 15, October 2006, Pages 1992-2001

PAGNONCELLI, D., VASCONCELOS FILHO, P. Sucesso empresarial planejado. Rio de Janeiro: Qualitymark, 1992.

PEANO, C.; R. Regulação tarifária do setor de distribuição de energia elétrica no Brasil: uma análise da metodologia de revisão tarifária adotada pela ANEEL. 119p. Dissertação (Mestrado em Energia) - Programa Interunidades de Pós-Graduação em Energia. São Paulo, 2005.

PELTZMAN, S., Toward a More General Theory of Regulation. Journal of Law and Economics, v.19, pp. 211-240, Ago. 1976.

PEREIRO, L. The valuation of closely-held companies in Latin America. Emerging Market Review, n. 2, pp. 330-370, 2001.

PINTO JUNIOR, H. Q. (Org.). Economia da Energia: Fundamentos Econômicos, Evolução Histórica e Organização Industrial, Rio de Janeiro: Elsevier, 2007.

; PIRES, M. C. Assimetria de Informações e Problemas Regulatórios.

Rio de Janeiro, ANP, fevereiro, 2000.

ROCHA, K.; BRAGANÇA, G.; CAMACHO, F. Remuneração de capital das distribuidoras de energia elétrica: uma análise comparativa, Rio de Janeiro: IPEA, 2006 (Texto para discussão).

SAMANEZ, C. P. Gestão de Investimentos e geração de valor, São Paulo: Pearson, 
Prentice Hall, 2007.

SHARPE, W. F. Capital asset prices: a theory of market equilibrium under conditions of risk. The Journal of Finance, v. 19, n.3, p.425-442,1964.

SMITH, A. The Wealth of nation. New York: Random House, 1994.

STEWART III, G. B. The Quest for value: the EVA management guide. New York :Harper Collins , 1991.

STERN STEWART. Setor elétrico continua no vermelho. Disponível em: <http://www.acendebrasil.com.br/site/materias/imprimir.asp?id=22841 >.Acesso em 30 ago. 2012.

STIGLER, G. J.; FRIEDLAND, C. What Can Regulators Regulate? The Case of Electricity, Journal of Law and Economics, v. 5, pp. 1-116, out. 1962.

STIGLER, G. J. The Theory of Economic Regulation. Bell Journal of Economics and Management Science, n.2, p. 3-21, Spring, 1971.

VAZ, C. E.; MAIA, J. L.; SANTOS, W. G. Tecnologia da indústria do gás natural, São Paulo: Blucher, 2008.

VISCUSI, W. K., VERNOM, J.M., HARRINGTON JR., J. E. Economics of Regulation and Antitrust .4th ed. Cambridge The MIT Press, 2000.

VOGELSANG, I. Incentive and regulation competition in public utility markets: a 20year perspective. Journal of Regulatory Economics, v.22, pp. 5-27, Jul., 2002.

WILLIAMSON, O. E. Markets and Hierarchies: analysis and antitrust implications. New York: Free Press, 1975.

YOUNG, S. D.; O`BYRNE, S. F. EVA and Value-Based Management: a practical guide to Implementation. New York: McGraw-Hill , 2001. 